UNIVERSIDADE DE SÃO PAULO

FACULDADE DE EDUCAÇÃO

ANTONIO CESAR BIGOTTO

Educação Ambiental e o desenvolvimento de atividades de ensino na escola pública.

SÃO PAULO

2008 


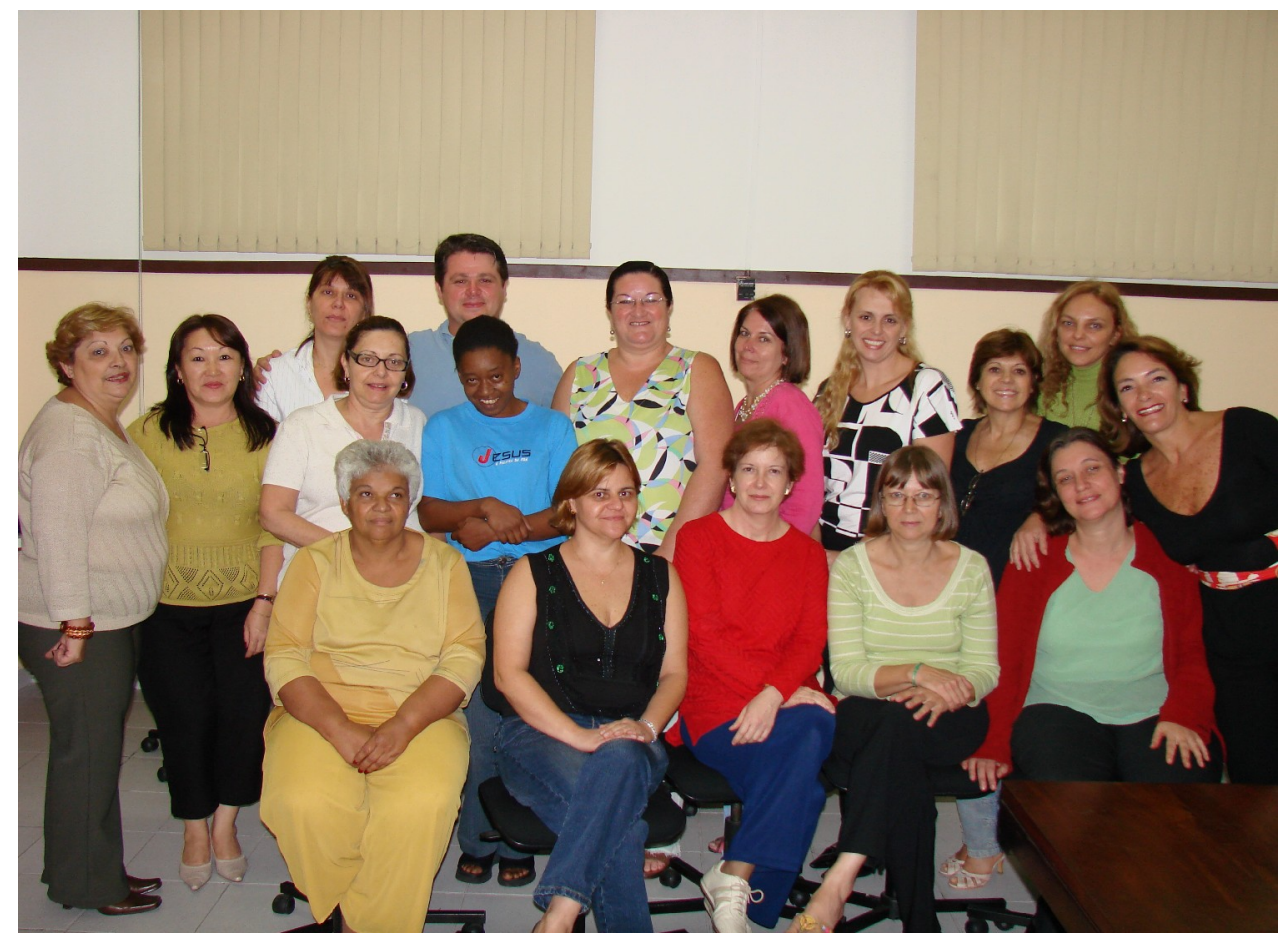

Amigos de caminhada pelas práticas de Educação Ambiental. 
ANTONIO CESAR BIGOTTO

Educação Ambiental e o desenvolvimento de atividades de ensino na escola pública

Dissertação apresentada à Faculdade de Educação da Universidade de São Paulo para a obtenção do título de Mestre em Educação.

Área de Concentração: Didática, Teorias de Ensino e Práticas Escolares.

Orientadora: Prof. Dra. Nídia Nacib Pontuschka.

SÃO PAULO

2008 
AUTORIZO A REPRODUÇÃO E DIVULGAÇÃO TOTAL OU PARCIAL DESTE TRABALHO, POR QUALQUER MEIO CONVENCIONAL OU ELETRÔNICO, PARA FINS DE ESTUDO E PESQUISA, DESDE QUE CITADA A FONTE.

Catalogação na Publicação

Serviço de Biblioteca e Documentação

Faculdade de Educação da Universidade de São Paulo

375.911

Bigotto, Antonio César

B594e

Educação ambiental e o desenvolvimento de atividades de ensino na escola pública / Antonio César Bigotto; orientação Nídia Nacib Pontuschka. São Paulo: s.n., 2008.

135 p.: il + anexos.

Dissertação (Mestrado - Programa de Pós-Graduação em Educação. Área de Concentração: Didática, Teorias de Ensino e Práticas Escolares) - - Faculdade de Educação da Universidade de São Paulo.

1. - Educação Ambiental 2. - Ensino fundamental 3. Prática de ensino 4. - Historia cultural - Psicologia 5. - Escola pública 6. - Interdisciplinaridade 7. - Projeto educacional I. Pontuschka, Nídia Nacib, orient. 


\section{FOLHA DE APROVAÇÃO}

Antonio César Bigotto

Educação Ambiental e o desenvolvimento de atividades de ensino na escola pública

Dissertação apresentada à Faculdade de Educação da Universidade de São Paulo para a obtenção do título de Mestre em Educação.

Área de Concentração: Didática, Teorias de Ensino e Práticas Escolares.

Aprovado em:

1

Banca Examinadora

Prof. Dr.

Instituição:

Assinatura:

Prof. Dr.

Instituição:

Assinatura:

Prof. Dr.

Instituição:

Assinatura: 
Aos meus pais, Toninho e Bete, exemplos de vida para mim, e para meus irmãos, Lígia e Bruno, pelo amor e carinho. 


\section{AGRADECIMENTOS}

À Nossa Senhora Aparecida, minha mãe e companheira em todos os momentos da minha vida.

Aos meus pais, que diante de todas as dificuldades souberam me dar exemplos de dignidade, respeito e solidariedade, mostrando-me sempre o valor do estudo, do trabalho e do conhecimento, e em especial à minha mãe, minha grande incentivadora em todos os momentos.

Ao amigo Alexandre, pelo apoio, incentivo e compreensão nos momentos difíceis e de ausência.

À Professora Drª . Nídia Nacib Pontuschka, por ter me acolhido generosamente nessa longa caminhada, pela sabedoria, calma, respeito e dedicação com que me orientou durante essa pesquisa.

Aos professores do Programa de Pós-Graduação, que muito contribuíram com essa pesquisa: $\operatorname{Prof}^{a}$ Dr $^{\mathrm{a}}$. Nídia Nacib Pontuschka, Prof ${ }^{\mathrm{o}}$. Dr. Pedro Roberto Jacobi, Prof ${ }^{\mathrm{o}}$. Dr. Jorge Manuel Nunes Ramos do Ó e em especial ao Prof ${ }^{\circ}$. Dr. Manoel Oriosvaldo de Moura, que além das ricas reflexões durante sua disciplina, me recebeu carinhosamente no Grupo de Estudos e Pesquisa da Atividade Pedagógica - GEPAPe.

Aos professores da Banca de Qualificação, a Prof ${ }^{a}$. Dr ${ }^{a}$. Maria Eliza Brefere Arnoni e o Prof ${ }^{\circ}$. Dr. Manoel Oriosvaldo de Moura, pelas preciosas contribuições e indicações bibliográficas oferecidas.

Ao grupo de estudo coordenado e orientado pela Prof ${ }^{a}$ Nídia Nacib Pontuschka, pela convivência, pelas trocas de idéias e informações, contribuições e reflexões desde a etapa inicial dessa pesquisa.

Aos pesquisadores do GEPAPe, pelo carinho com que me acolheram e partilharam suas pesquisas.

Aos funcionários da FEUSP, em especial aos funcionários da Secretaria de PósGraduação e aos funcionários da Biblioteca, que solicitamente deram todo o apoio para o desenvolvimento e conclusão dessa pesquisa.

À Diretoria de Ensino Centro Sul, e em especial à Oficina Pedagógica, na pessoa do ATP e amigo Ariovaldo da Silva Stella, pelo apoio e incentivo dado durante o desenvolvimento das oficinas de Educação Ambiental. 
Às professoras do Ensino Fundamental I, Ana Claudia, Ana Cristina, Antonia, Denise, Elizabete, Fabiana, Gláucia, Ilka, Isaura, Maria Akemi, Maria Izabel, Maria Helena, Maria de Lourdes, Maria Sônia, Margarete, Idelize, Mariani, Rosemary, Sandra e Silvana, que participaram das Oficinas e cujos relatos, depoimentos e reflexões foram essenciais para a conclusão deste trabalho.

À Professora e amiga Maria José, pela leitura e revisão cuidadosa e por suas palavras sempre de apoio e incentivo.

À amiga Paula, pela tradução e revisão do resumo para a língua inglesa.

Ao amigo Marcio pelos socorros tecnológicos e dicas de formatação.

Às professoras e amigas das escolas municipais da Prefeitura de Jales, onde iniciei minha carreira, em especial à Bethi, Mirtes, Silvia e Sônia Carmelin, pelo carinho, apoio e incentivo.

Aos amigos de trabalho da escola Ataliba de Oliveira, pelo apoio e compreensão nos momentos de ausência.

A todos que estiveram comigo durante essa caminhada, meu muito obrigado. 
“...todo esse estudo, essas reflexões me tornaram uma pessoa mais crítica e consciente. Eu mudei e minhas práticas também mudaram. Consigo enxergar coisas que antes eu não via e por isso tenho refletido mais sobre minhas atitudes e práticas docentes. Estou mais segura e isso me deixa muito feliz".

Depoimento da Professora da UE 07 em 21/05/2007. 


\section{RESUMO}

BIGOTTO, Antonio César. Educação Ambiental e o desenvolvimento de atividades de ensino na escola pública. 2008. 135 f. Dissertação (Mestrado em Educação) - Faculdade de Educação, Universidade de São Paulo, São Paulo, 2008.

A presente dissertação foi elaborada com o objetivo de analisar o desenvolvimento de práticas de Educação Ambiental nas escolas públicas como forma de compreender sua organização, fundamentação teórica e metodológica nas atividades pedagógicas de professoras de $3^{\mathrm{a}}$ e $4^{\mathrm{a}}$ séries do Ensino Fundamental da Diretoria de Ensino Centro Sul, na cidade de São Paulo. Para tanto, partimos dos fundamentos filosóficos da crise ecológica atual com o intuito de compreendermos as práticas de Educação Ambiental como atividade humana. Nesse sentido, a base teórica que deu sustentação à investigação partiu da psicologia histórico-cultural, em particular da Teoria da Atividade, baseando-se principalmente nas contribuições de Vygotsky, Leontiev e Davydov. Esta dissertação desenvolveu-se no sentido de uma pesquisa qualitativa, de natureza exploratória, envolvendo elaboração teórica em um diálogo permanente entre os dados coletados e a teoria de base. Orientada pela perspectiva sócio-histórica, a compreensão dos fenômenos ocorreu a partir de um acontecer histórico na relação e dialogicidade entre sujeitos. Como parte empírica, elaboramos e coordenamos uma Oficina de Educação Ambiental com seis encontros entre os anos de 2006 e 2007, com 21 professoras todas de $3^{\mathrm{a}}$ e $4^{\mathrm{a}}$ séries do ensino fundamental, trabalho este que nos aproximou do processo de elaboração e desenvolvimento das práticas de Educação Ambiental. Com esse trabalho, pudemos confirmar que ainda existe um grande descompasso e distanciamento entre o que é discutido e proposto pela escola e para a escola com aquilo que realmente vem sendo feito e que uma das alternativas para o desenvolvimento da temática ambiental é investir no trabalho com projetos interdisciplinares.

PALAVRAS - CHAVE: educação ambiental; atividades de ensino; Psicologia históricocultural; Teoria da Atividade; projetos educacionais; interdisciplinaridade. 


\begin{abstract}
BIGOTTO, Antonio Cesar. Environmental education and the development of teaching activities at public schools. 2008. 135f. Dissertation (Master's Degree in Education) Faculdade de Educação, Universidade de São Paulo, 2008.

The aim of this paper is to analyse the development of environmental education practices at public schools as a way of understanding its organization, theoretical and methodological approach in the pedagogical activities of third and fourth grade Primary School teachers from "Diretoria de Ensino Centro Sul" in the city of São Paulo. In order to do this, we started with the philosophical basis of the present ecological crisis aiming at understanding the environmental education practices as a human activity. This way, the theory which has endorsed the investigation departed from the cultural and historical psychology, particularly from the Activity Theory, based mainly on the contributions of Vygotsky, Leontiev and Davydov. This paper has been developed as a qualitative research with investigative nature, involving theoretical elaboration in an everlasting dialogue between the collected data and the supporting theory. The understanding of the phenomena was led by the social and historical perspective in the relationship and dialogue among subjects. As an empiric phase, we worked out and coordinated an environmental education workshop with six meetings between 2006 and 2007, with 21 third and fourth grade Primary School teachers, work which enabled us to approach the creation and development process of the environmental education practices. This work has made it possible for us to confirm that there is still a great gap between what is discussed and proposed by the school and for the school and what is actually being carried out. One of the alternatives for the development of the environmental theme is investing in interdisciplinary projects.
\end{abstract}

Key words: Environmental education; teaching activities; cultural and historical psychology; Activity Theory; projects education; interdisciplinarity. 


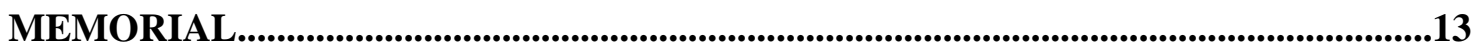

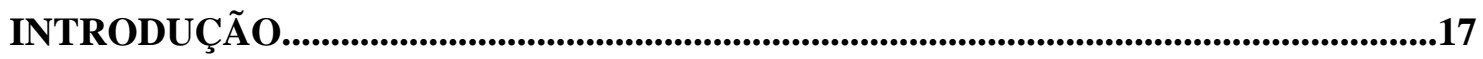

\section{CAPÍTULO I}

\section{EDUCAÇÃO AMBIENTAL COMO ATIVIDADE HUMANA}

Educação Ambiental e a Crise Ecológica Atual: Fundamentos Filosóficos.......................27

A Educação Ambiental e a Sociedade de Risco...................................................................32

Saber Ambiental: Cidadania e Interdisciplinaridade....................................................36

Ensinar e Aprender nos PCNs........................................................................................................45

Temas Transversais: Uma proposta para a Educação Ambiental........................................47

Práticas Educativas de Educação Ambiental como Atividade Humana.............................49

Abordagens Psicologias da Atividade Humana.................................................................................51

A Teoria da Atividade..............................................................................................................................54

Atividade de Estudo, Atividade de Aprendizagem e Atividade Orientadora de

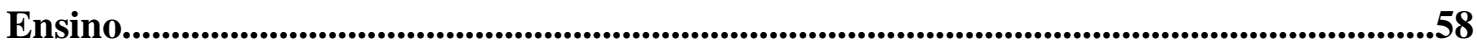

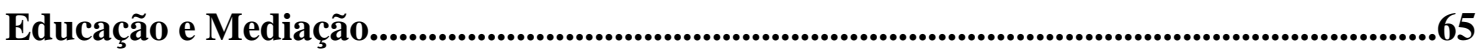

\section{CAPÍTULO II}

PRÁTICAS DE EDUCAÇÃO AMBIENTAL NAS ESCOLAS DE ENSINO FUNDAMENTAL DA DIRETORIA DE ENSINO CENTRO SUL

Caracterização da Área e das Escolas envolvidas na Pesquisa..........................................68

A Pesquisa Qualitativa na Perspectiva Sócio-Histórica........................................................76

Instrumentos de Pesquisa.....................................................................................................................82

Educação Ambiental na Diretoria Centro Sul............................................................87 


\section{CAPÍTULO III}

ATIVIDADES DE EDUCAÇÃO AMBIENTAL NO ENSINO FUNDAMENTAL I: UMA EXPERIÊNCIA

O Surgimento das Atividades de Educação Ambiental.............................................................90

Conteúdos de Meio Ambiente Propostos pelo PCN...................................................................97

Educação Ambiental e os Projetos Interdisciplinares............................................................101

Práticas de Educação Ambiental e as Atividades de Ensino e Aprendizagem.................108

Educação Ambiental e a Formação Docente..........................................................................110

CONSIDERAÇÕES FINAIS.....................................................................................................114

REFERÊNCIAS......................................................................................................................119

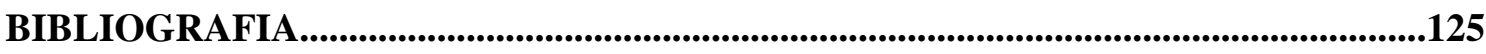

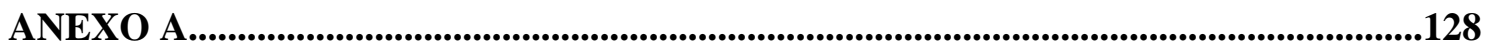

ANEXO B.....................................................................................................................129

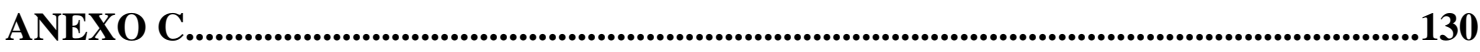

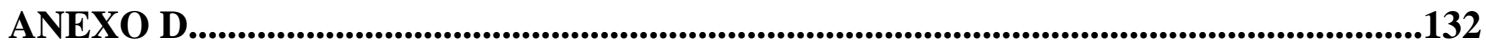

ANEXO E.........................................................................................................................134 


\section{MEMORIAL}

Natural de Jales, cidade do interior do Estado de São Paulo, tive uma infância bastante simples como todas as crianças que viviam na zona rural naquela época. Morei no sítio com meus pais até os 24 anos de idade, quando vim para São Paulo em busca de novos horizontes, principalmente em relação aos meus estudos.

Enquanto criança no sítio, brincava com meus vizinhos através de brincadeiras muito simples, brinquedos improvisados com sucata, frutas, banhos no rio e tudo mais que a imaginação desse conta. Cresci ouvindo as histórias dos mais velhos principalmente sobre a vida no campo, onde aprendi a entender alguns sinais da natureza, como a aproximação de chuvas com o canto de um pássaro, observando a lua, o vento, etc. Sempre estive em contato muito próximo com a natureza.

Em 1983, iniciei minha vida escolar, mesmo ano do nascimento de minha irmã. Estudei até a quarta série primária, hoje Ensino Fundamental I, em uma escola na zona rural, também chamada de isolada. Era uma sala única onde ficavam duas turmas para uma mesma professora: de manhã terceira e quarta série e à tarde primeira e segunda série. Apesar de meus pais só terem estudado até a quarta série primária eles sempre me incentivaram a estudar e com eles aprendi a respeitar e a admirar meus professores como exemplos de vida a serem seguidos.

Para prosseguir meus estudos, fui matriculado no ano de 1987 em uma grande escola pública na cidade de $1^{\circ}$ e $2^{\circ}$ grau, hoje de Ensino Fundamental e Médio, onde cursei até a $8^{\mathrm{a}}$ série. Estudava de manhã, e à tarde ajudava meus pais nas tarefas do sítio, principalmente na época da colheita do café, de onde vinha nosso sustento.

Sempre tive bons professores, pelo menos são destes que me recordo com carinho e saudades. Alguns deles sem dúvida marcaram minha vida para sempre. Uma foi minha professora de Geografia ainda na quinta série. Por mais tradicional que ela pudesse ser, às vezes, pelo menos hoje consigo compreender assim, com seus questionários intermináveis, ela era uma pessoa muito dinâmica, alegre e amiga de todos os alunos. Conseguia transformar os conteúdos mais chatos de serem estudados em aulas divertidas e agradáveis. Hoje procuro ter esse dinamismo em minhas aulas, ser alegre e principalmente amigo de todos os meus alunos e percebo que isso é muito importante.

Outro professor bastante importante em minha vida foi minha professora de Ciências e que também me deu aula de Biologia no Ensino Médio. Para mim, professor de Ciências era "Cientista", com todos aqueles experimentos, conhecimentos sobre o ar, a água e o solo, aulas 
de laboratório, e era isso o que eu queria ser: um cientista. Hoje sou professor de Ciências e Biologia.

Em 1991, já em busca de uma profissionalização, cursei o Ensino Médio no CEFAM ${ }^{1}$ de Jales. Durante os três primeiros anos, no período da manhã, cursava o Ensino Médio regular e no período da tarde a parte pedagógica específica, uma vez que o curso era de período integral, e no quarto ano, somente a parte específica, ou seja, de preparação e formação pedagógica. Muitas horas de estágio e docência supervisionada me fizeram ter certeza de que era no magistério que eu me encontraria profissionalmente e de que era isso que eu queria para minha vida: ser professor.

Estes quatro anos de formação e habilitação para o magistério foram bastante importantes na minha vida. Cresci muito como pessoa, principalmente no desenvolvimento de um senso crítico sobre o mundo e as coisas ao meu redor.

Como recebia um salário mínimo de ajuda de custo mensalmente, passei a ser independente financeiramente aos quinze anos de idade ajudando em casa sempre que possível.

No magistério tive excelentes professores que marcaram muito minha vida profissional. Hoje como professor, um profissional da Educação, procuro resgatar e transmitir tudo o que me foi passado por essas pessoas: acreditar na Educação, pois só através dela poderemos ter um mundo mais justo e equilibrado.

Como ao terminar o Magistério eu já tinha claro o que eu queria para minha vida, em 1995 iniciei minha graduação no curso de Ciências com habilitação em Biologia, na cidade de Jales. Ano este cheio de acontecimentos importantes: meu primeiro emprego na APAE (Associação de Pais e Amigos dos Excepcionais) de Jales, onde atuei como professor por três anos, o nascimento do meu irmão, completando assim minha família e minha aprovação no concurso Público Municipal para o cargo de Professor de Educação Infantil e Ensino Básico $\mathrm{I}^{2}$, onde atuei por cinco anos, até vir para São Paulo no ano de 2000.

O curso de Biologia foi muito prazeroso apesar de ter que conciliá-lo com minhas aulas no período da manhã na APAE e à tarde na prefeitura. Durante o curso, acabei me interessando mais pela área da Ecologia, pelos relacionamentos dos seres vivos entre si e com o meio que os cercam até chegar nas questões relacionadas com a Educação Ambiental. Como trabalho de conclusão de curso, fiz um estudo sobre o impacto ambiental causado pela instalação de um Curtume já em fase final de construção na cidade, perto do bairro onde

\footnotetext{
${ }^{1}$ Centro Específico de Formação e Aperfeiçoamento do Magistério.

${ }^{2}$ Referente hoje ao Ensino Fundamental I.
} 
ficava minha escola e ao qual pertencia a maioria dos meus alunos. Analisando os rios que cercavam a cidade e que poderiam receber os resíduos deste local, acabei voltando para a cidade e percebendo que o problema de poluição já existia e que este estava relacionado com o saneamento básico. Como resultado deste estudo, fui convidado a escrever uma matéria para o jornal da cidade, Jornal de Jales, cujo título era: Saneamento básico, acima de tudo uma questão de Educação.

Durante esse período, já em sala de aula como professor de uma segunda série do Ensino Fundamental I, comecei a dar mais destaque às atividades de Educação Ambiental, procurando trabalhar com os problemas que faziam parte da realidade dos meus alunos. Fiz alguns projetos maiores que mobilizaram a escola toda, mas percebia que com o passar do tempo não havia uma mudança significativa de comportamento nos alunos. A partir daí comecei então a me questionar sobre como as atividades de Educação Ambiental deveriam ser organizadas e desenvolvidas.

Ao terminar o curso de Biologia, em 1998, iniciei o Curso de Pedagogia, buscando aprimorar ainda mais meus conhecimentos pedagógicos e aos sábados pude freqüentar um curso de Especialização no ensino de Ciência e Biologia, onde pude ter maior contato com o mundo acadêmico do ensino e da pesquisa, pois todos os professores vinham de Universidades de fora trazendo novos conhecimentos principalmente sobre as pesquisas em andamento. A partir deste momento comecei a pensar nas minhas questões de Educação Ambiental como um problema maior que pudesse ser investigado. Neste mesmo ano fui aprovado no concurso Público para professor da Rede Pública Estadual na disciplina de Biologia

Em Dezembro de 2000 deixei o sítio, a casa dos meus pais, meus irmãos e vim para São Paulo para uma nova fase que se iniciava em minha vida. Agora longe da família, tinha que me virar e caminhar por conta própria. O ano letivo de 2001 se iniciou e eu tive que pegar aulas como professor eventual enquanto aguardava o chamado para assumir meu cargo o que aconteceu no segundo semestre deste mesmo ano. Assumi meu cargo na Escola Estadual Prof. Ataliba de Oliveira, no bairro de São João Clímaco, na cidade de São Paulo, pertencente à Diretoria de Ensino da Região Centro Sul. Ainda hoje continuo na mesma escola e já sou bastante conhecido pelos alunos e pela comunidade.

Depois de me acostumar melhor com a vida na cidade grande e de criar coragem para enfrentar o trânsito longe de casa, procurei a Faculdade de Educação da Universidade de São Paulo, onde freqüentei como aluno ouvinte uma disciplina de Pós-Graduação chamada “A Educação Ambiental e a Formação de Professores através da pesquisa interdisciplinar: teoria 
e método", o que me ajudou a organizar as idéias e a escrever um projeto de pesquisa sobre o problema que já me acompanhava desde meu tempo de professor no Ensino Fundamental I em Jales com meus alunos de segunda série.

Em 2004, visando dar continuidade aos meus estudos, tentei o mestrado pela Faculdade de Educação da Universidade de São Paulo, onde fui aprovado e iniciei assim a Pós-Graduação no ano de 2005 na linha de pesquisa Didática, Teorias de Ensino e Práticas Escolares, sob a coordenação da Prof. Dra. Nídia Nacib Pontuschka.

Mesmo tendo conseguido uma bolsa de estudo pelo Projeto Bolsa Mestrado da Secretaria Estadual de Educação do Governo de São Paulo, optei por continuar com minha jornada de trabalho ${ }^{3}$ de 25 horas/aulas semanais na disciplina de Biologia enquanto realizava as disciplinas do Programa de Pós-Graduação em Educação.

Antonio César Bigotto.

São Paulo, Dezembro de 2007.

${ }^{3}$ artigo $4^{\circ}$, inciso I da Resolução SE 131, de 04/12/2003 - ajuda financeira de R \$ 720,00 (setecentos e vinte reais) mensais. 


\section{INTRODUÇÃO}

Pensar em práticas educativas de Educação Ambiental (EA) pressupõe antes de tudo em pensar a problemática ambiental na sua gênese, que segundo Leff (2002) se deu num processo histórico dominado pela expansão do modo de produção capitalista. Assim ela surgiu no final do século XX como uma crise de civilização em uma ordem econômica mundial marcada pela desigualdade entre nações e classes sociais.

Crise essa marcada por um mundo carregado e perigoso com profundas transformações destrutivas, principalmente com relação ao meio ambiente, constituindo assim segundo Giddens (1991), os ambientes de risco.

Diante desses riscos e da capacidade da sociedade em percebê-los e discuti-los, Beck (1994) desenvolve o conceito de modernização reflexiva, que traz consigo um elemento novo, a reflexividade, ou seja, a capacidade de perceber os riscos e de reagir diante deles. Com isso, diversas questões, dentre elas a ambiental, começam a fazer parte do cotidiano das pessoas.

Atualmente, a questão ambiental está cada vez mais presente no cotidiano da sociedade contemporânea e assim a Educação Ambiental desponta como uma possibilidade de reencantamento, abrindo possibilidades de novos conhecimentos, metodologias e habilidades na perspectiva de uma educação interdisciplinar (JACOBI, 2001).

A crise ambiental traz uma crítica ao modelo de crescimento econômico e também ao modelo epistemológico e neste embate propõe o desafio de repensar a educação na sua totalidade, enfrentando a fragmentação do conhecimento. Para Silva (et al., 2006), a ciência moderna não soube o que fazer da complexidade e a estratégia foi reduzir o complexo ao simples, do qual nasceram os vários saberes parcelares e as várias especialidades. Ganhou-se em aprofundamento, mas perdeu-se a totalidade.

Como exemplifica Boff:

A natureza e o universo não constituem simplesmente o conjunto de objetos existentes, como pensava a ciência moderna. Constituem sim uma teia de relações, em constante interação. Os seres que interagem deixam de ser objetos. Eles se fazem sujeitos, sempre relacionados e interconectados, formando um complexo sistema de inter-retro-relações (BOFF, 1997, p. 72).

Segundo Carvalho (2004), a crise ambiental alimenta questionamentos epistemológicos, pois desacomoda os modos já aprendidos de pensar da racionalidade 
moderna ${ }^{4}$, ao expor a insuficiência dos saberes disciplinares para que se compreenda a complexidade das inter-relações na base dos problemas ecológicos.

A questão ambiental, problemática da sociedade, e condicionada pela complexidade do pensar e do agir ambiental, exige da sociedade e da Educação em especial, respostas e encaminhamentos de fundamental importância para a sobrevivência da natureza. Nesse sentido, de acordo com Arnoni (2003) tendo como pressuposto que a natureza humana é produzida pelo homem, a Educação, na dependência do trabalho educativo que desenvolve, pode interferir (ou não) na produção dessa natureza humana e, conseqüentemente na transformação da natureza, no sentido amplo do termo, vinculando assim, a Educação às ações relacionadas à problemática ambiental.

As diferentes abordagens sobre a temática ambiental por muitos agentes e segmentos da sociedade, em especial pela mídia, tem levado à formação de alguns preconceitos e à veiculação de imagens distorcidas sobre as questões relativas ao meio ambiente (PCN, 1997). Segundo Bittencourt (1996), a identificação dos problemas ambientais como poluição, degradação, desmatamento, associada à questão do "modismo" transformou a temática ambiental inevitável aos currículos escolares.

Segundo Simões (1995), a introdução do aspecto ambiental no processo educativo ocorreu de forma gradativa, manifestando-se inicialmente por meio das Propostas Curriculares de Ciências e Geografia, elaboradas pela Coordenadoria de Estudos e Normas Pedagógicas (CENP) da Secretaria Estadual da Educação de São Paulo, através de projetos de órgãos ambientais e de algumas organizações não-ambientais (ONGs), assim como por tentativas individuais de alguns educadores. Somente a partir de 1997, com o lançamento dos Parâmetros Curriculares Nacionais (PCNs), pelo Ministério da Educação e do Desporto com a temática meio ambiente como tema transversal é que a Educação Ambiental realmente passa a integrar os currículos escolares, mas sem grandes discussões e reflexões.

A escola foi um dos primeiros espaços a absorver esse processo de "ambientalização" da sociedade, recebendo sua cota de responsabilidade para melhorar a qualidade de vida da população, através da informação e da conscientização. Percebe-se, porém, que no âmbito educacional existe uma distância e um descompasso entre a ação e sua eficácia pedagógica e social (SEGURA,1999).

\footnotetext{
4 Modelo que alcançou sua formulação mais acabada com o filósofo René Descartes no século XVII, representando importante ruptura com os modelos anteriores, os quais situavam a compreensão do real em instâncias de legitimação externas ao mundo humano, ao contrário da racionalidade moderna que trouxe a legitimação do conhecimento para dentro do mundo humano, onde o sujeito humano é entendido como sujeito da razão e capaz de pensar logicamente (racionalmente) podendo chegar a uma compreensão objetiva e real (CARVALHO, 2004).
} 
Com isso passamos a perceber a existência de muitos trabalhos pontuais, de projetos que não se articulam ao projeto político-pedagógico da escola, sem continuidade e constituindo-se em experiências isoladas. De acordo com Pontuschka (1999), o estudo das questões ambientais e a consciência da importância do sistema Terra, no Ensino Fundamental e Médio, vem sendo lento, havendo somente tentativas pontuais, muitas vezes, desvinculadas do currículo da escola.

Para Tristão (2005), as palavras comuns, freqüentemente utilizadas nos discursos de Educação Ambiental, começaram a parecer sem sabor ${ }^{5}$ e a soar como falsas e vazias, tornando o cotidiano estressante e (des)potencializando as práticas dos sujeitos sociais, o que pode ser elemento desencadeador da sensação de frustração e angústia que sentem, às vezes, professores e educadores ambientais, pelo gigantesco ideal de reverter o quadro de destruição dos bens naturais e resgatar a relação cultura/natureza e sociedade/meio ambiente.

O uso cada vez mais corrente e generalizado da denominação Educação Ambiental pode contribuir para uma visão ingênua da idéia contida nela, como se ela fosse à reunião de palavras com o poder para resolver todos os problemas e onde se possam ensinar as pessoas a serem gentis e cuidadosas com a natureza (CARVALHO, 2004). Ainda de acordo com outros autores, essa ingenuidade e posturas pouco críticas, podem acabar levando os educadores a reproduzirem um discurso dominante e conservador, o que se reflete em práticas ingênuas, apesar de bem intencionadas, como observado durante a realização das oficinas.

De acordo com Arnoni (2003), os caminhos possíveis para se trabalhar aspectos da temática ambiental, numa perspectiva crítica, exigem que o ambiente não seja considerado como algo externo, distante e alheio ao homem; que as questões ambientais não sejam trabalhadas de forma fragmentada, a partir de ações disciplinarizadas e estanques; que as práticas pedagógicas não se destinem quase que, exclusivamente, a transmitirem os conhecimentos científicos dessa área e que, preferencialmente, não reforcem a dependência do homem ao ambiente, apenas no âmbito da relação material e mecânica de sua sobrevivência.

Como parte empírica de nossa pesquisa, coordenamos e desenvolvemos uma Oficina de Educação Ambiental $^{6}$ na Diretoria de Ensino Centro Sul, na cidade de São Paulo, onde conseguimos formar um grupo inicial com 30 professoras, mas devido a problemas como ingresso de novos professores por concurso público, alteração de escolas, acabamos ficando

\footnotetext{
${ }^{5}$ Segundo a autora, "Sabor e saber têm a mesma raiz etimológica. Precisamos resgatar o sabor do saber que está no desejo de mudar a vida" (TRISTÃO, 2005, p. 253).

6 "Educação Ambiental na $3^{\mathrm{a}}$ e $4^{\mathrm{a}}$ séries do Ensino Fundamental: prática e percepções".
} 
com um grupo permanente de 19, todas trabalhando com alunos de $3^{\mathrm{a}}$ e $4^{\mathrm{a}}$ séries do Ensino Fundamental I, tanto no período matutino como vespertino. Com o desenvolver dos trabalhos, passamos a perceber que as oficinas, não se constituíam apenas em momentos para análise e coleta de dados, mas pelo contrário, em ricos momentos para troca de idéias, experiências e informações, num verdadeiro exercício da dialética, como podemos perceber no depoimento de uma professora durante a realização da primeira oficina, quando questionada sobre o que tinha achada da proposta de trabalho:

Prof. (UE15): "Muito boa, pois nos leva a refletir, pesquisar e colocar em prática na sala de aula atividades e experiências trocadas nesse encontro; instiga a reflexão da sua prática pedagógica e de comportamentos em nossa própria vida”.

As professoras na sua grande maioria têm apontado para a falta de materiais de apoio, informações, como uma das maiores dificuldades para se desenvolver as atividades de Educação Ambiental. Pontuschka afirma que:

O professor nem sempre pode contribuir satisfatoriamente com projetos de educação ambiental, apesar de presentes na última Constituição Brasileira, porque ele não tem informações e recursos didáticos suficientes para propor pesquisas em sala de aula ou na escola, para que os estudantes possam trabalhar com documentos já existentes e tenham condição, sob a orientação do professor, de produzir novos documentos que auxiliem a ambos na reflexão e solução de certos problemas (PONTUSCHKA, 1999, p.8).

A partir disso, algumas questões iniciais começaram a se mostrar e instigaram o presente estudo, tais como: qual é o verdadeiro papel das práticas de Educação Ambiental desenvolvidas no Ensino Fundamental I? Quais as correntes de Educação Ambiental que influenciam as práticas dos professores envolvidos nesse processo? Como as práticas de Educação Ambiental são desenvolvidas metodologicamente? São os próprios professores que escolhem os temas com os quais querem trabalhar ou existe um projeto único que coordena estas práticas? Se existe um projeto único, quem é responsável por sua proposição, encaminhamento e avaliação? As práticas de Educação Ambiental são desenvolvidas no plano escolar de forma interdisciplinar ou em uma disciplina específica? As práticas de Educação Ambiental, da forma como estão sendo desenvolvidas se constituem como atividades de aprendizagem? 
Sabemos que os questionamentos apresentados são muitos e não temos a intenção de nos aprofundar na investigação de todos, nem mesmo estamos propondo a criação de um manual de como trabalhar com a Educação Ambiental no Ensino Fundamental I, pois temos consciência da complexidade envolvida em todas essas questões. Nossa intenção com essa pesquisa é de fazer um exercício para refletir e propor caminhos que iluminem o fazer das práticas de Educação Ambiental, de desenvolver um trabalho crítico e consciente, na perspectiva de uma educação como fonte de motivação e de mudanças sociais significativas. Sendo assim, faremos um aprofundamento nas questões relacionadas com as práticas de Educação Ambiental enquanto atividades que buscam formar cidadãos críticos e conscientes de sua realidade.

Ao destacar nosso interesse pelas práticas de Educação Ambiental, não queremos dizer que vamos analisar somente uma Educação Ambiental voltada para o "pragmatismo", mas para além disso propomos uma análise de uma Educação Ambiental que se deseja crítica e emancipatória que não nega os conflitos existentes na sociedade e prepara os indivíduos para viver neste contexto, numa perspectiva de participação. Segundo Simões (1995, p. 27), "embora a EA tenha sua origem justamente na necessidade de resolver problemas, e é esse caráter pragmático que lhe dá identidade, torna-se imprescindível transcender essa motivação inicial para sustentar-lhe [à EA] um significado".

Para analisarmos se as práticas de Educação Ambiental se constituem como "Atividades de Aprendizagem", trabalhamos com base na "Teoria da Atividade" desenvolvida principalmente por Vigotski ${ }^{7}$, Alexei Leontiev e Alexandr Luria. Segundo Hedegaard e Lompscher (1999 apud SERRÃO, 2004, p. 133) ${ }^{8}$, baseando-se nos pressupostos teóricometodológicos de Leontiev, "a atividade de aprendizagem é um tipo especial de atividade dirigida para a aquisição de habilidades e conhecimento social por meio da re-produção individual mediante ações de aprendizagem especiais sobre os objetos de aprendizagem (métodos e conhecimento do assunto)". Para Serrão (2004, p. 133), pode-se "ainda acrescentar que a atividade de aprendizagem ocorre privilegiadamente no âmbito da educação escolar, em uma instituição específica: a escola, independente do nível de ensino que ela ofereça".

\footnotetext{
${ }^{7}$ Neste texto será assumida a grafia "Vigotski", pois muitas são as formas de escrita desse nome de origem russa devido principalmente aos procedimentos de transliteração do alfabeto cirílico para o ocidental. Entretanto, quando se fizer necessária alguma referência bibliográfica desse autor em outra língua ou tradução de outra língua, manter-se-á grafia que consta em tais publicações.

${ }^{8}$ HEDEGAARD, Mariane and LOMPSCHER, Joaquim. Learning activity and development. Aarhus: Aarhus University Press, 1999.
} 
Nossa preocupação com as práticas de Educação Ambiental se deve ao fato de considerarmos que de nada adianta continuarmos insistindo em um processo de ensino e de aprendizagem que traz o ambiente e as relações entre os seres vivos de forma fragmentada e particularizada. Pelo contrário, há a necessidade de se buscar atividades de aprendizagem voltadas para o reconhecimento dos direitos e deveres de cada um, ressaltando os valores de cidadania, em atividades onde o educando possa apropriar-se de seu ambiente, internalizando suas ações e formando com ele um sistema orgânico e equilibrado. (LINDNER, 2006).

A opção de trabalhar com as $3^{\mathrm{a}}$ e $4^{\mathrm{a}}$ séries do Ensino Fundamental $\mathrm{I}^{9}$ deve-se ao fato de considerarmos este nível o primeiro contato de muitos com o mundo da escrita, com uma educação sistematizada, em um momento de muitas descobertas, onde o professor tem um papel bastante importante na formação de valores, posturas e atitudes que poderão perdurar por toda a vida de uma pessoa, além de ser uma fase de escolarização em que o pesquisador já atuou como docente, apresentando assim um maior conhecimento. Acreditamos que sob essa perspectiva, é muito mais fácil formar um cidadão consciente e com comportamentos "ambientalmente corretos" desde pequenos, do que tentar mudar um adulto cheio de vícios, preconceitos e com valores insustentáveis de consumismo, desperdício, violência, egoísmo e desrespeito (PCN, 1997).

Em função dos questionamentos apresentados anteriormente serem respondidos e na busca de conhecer mais um dos percursos possíveis na construção de um saber em Educação Ambiental, estabeleceu-se o seguinte problema de pesquisa a ser investigado: Como as práticas de Educação Ambiental desenvolvidas pelas professoras de $3^{\mathrm{a}}$ e $4^{\mathrm{a}}$ séries do Ensino Fundamental da Diretoria de Ensino Centro Sul estão organizadas, que referenciais teóricos a sustentem e como são desenvolvidas metodologicamente?

O que estamos propondo de forma geral é um estudo sobre o trabalho educativo que segundo Arnoni (2003) é o ato de produzir, direta e intencionalmente, em cada indivíduo, a humanidade que é produzida histórica e coletivamente pelo conjunto dos homens. Compreendido dessa forma, ainda segundo a autora, o trabalho educativo constitui a identificação dos elementos culturais que precisam ser assimilados pelos indivíduos da espécie humana e a descoberta das formas mais adequadas para atingir esse objetivo.

Segundo Duarte (1998), o trabalho educativo alcança sua finalidade, quando cada indivíduo singular apropria-se da humanidade produzida histórica e coletivamente. Dessa

\footnotetext{
${ }^{9}$ Séries estas que poderão corresponder às $4^{\mathrm{a}}$ e $5^{\mathrm{a}}$ séries do Ensino Fundamental de 9 anos no Sistema de Ensino do Estado de São Paulo, conforme a Declaração do Conselho Estadual de Educação (CEE) nº 61/2006 da resolução de 08 de Dezembro de 2006.
} 
forma, trata-se de proporcionar aos indivíduos a apropriação de algo que já foi historicamente produzido pelo trabalho educativo, uma atividade intencionalmente dirigida por fins, nesse caso, a elaboração da práxis crítica ${ }^{10}$ (Arnoni, 2003).

Acreditamos que se as práticas de Educação Ambiental apoiarem-se em referenciais teóricos que concebam práticas interdisciplinares, na perspectiva de uma educação emancipatória, como a entendida por Paulo Freire e compartilhada por Manzochi, como veremos a seguir, de totalidade, que respeite e pratique o diálogo e a utopia, teremos a oportunidade de atingir através de uma práxis crítica os objetivos maiores de uma Educação Ambiental que é o de "contribuir para a formação de cidadãos conscientes, aptos para decidirem e atuarem na realidade socioambiental de um modo comprometido com a vida, com o bem-estar de cada um e das sociedades local e global" PCN (1997, p. 29).

Para Kosík:

\begin{abstract}
A práxis na sua essência e universalidade é a revelação do segredo do homem como ser ontocríativo, como ser que cria a realidade (humano-social) e que, portanto, compreende a realidade (humana e não-humana, a realidade na sua totalidade)... A práxis é ativa, é atividade que se produz historicamente - que dizer, que se renova continuamente e se constitui praticamente - unidade do homem e do mundo, da matéria e do espírito, de sujeito e objeto, do produto e da produtividade. (KOSÍK, 1995 , p. 222, grifos do autor).
\end{abstract}

Assim, de acordo com o autor, o que quer que o homem faça - em sentido afirmativo ou negativo - dá lugar a um determinado modo de existência no mundo e determina (consciente ou inconscientemente) a sua posição no universo. Pelo simples fato de existir, o homem se coloca em relação com o mundo e esta sua relação subsiste antes mesmo que ele passe a considerá-la e dela faça objeto de investigação, e antes mesmo que a confirme ou a negue prática ou intelectualmente. Assim, entendendo a posição do homem no universo como práxis, pode-se inferir a existência de diferentes estágios ou estados da práxis e também, presumir a sua superação. Nesse sentido, segundo Arnoni (2003) a possibilidade de transformar a própria práxis, do estado atual para outro, é de fundamental importância para a discussão da temática ambiental, em especial no que se refere ao ensino. Para a autora, a

\footnotetext{
${ }^{10}$ Práxis crítica é a atividade humano-social, de caráter mediato, gerada pela relação dialética entre a natureza e o homem, compreendendo o mundo como totalidade complexa e dinâmica, ou seja, a síntese de múltiplas determinações. A intencionalidade é a humanização.
} 
possibilidade de o sujeito passar de um nível ao outro pela ruptura com a práxis comum ${ }^{11}$ à atual ocorre quando o sujeito, ao entender a práxis comum e nela se entender, ao contextualizar e nela se contextualizar, consegue dela se libertar, superando-a pela incorporação de aspectos da práxis crítica.

Nessa perspectiva, dentre os fatores que interferem na mudança de estado da práxis atual encontra-se o trabalho educativo, que já comentamos anteriormente. Para Arnoni (2003), o trabalho educativo prioriza como um dos valores fundamentais da educação, o desenvolvimento do indivíduo pela superação dialética da práxis. Para isso, segundo a autora:

\begin{abstract}
...a organização das situações de ensino por ele desenvolvida potencializa que as qualidades da práxis atual sejam negadas pela inclusão de qualidades da práxis inovadora pretendida. Assim, por apropriação, as qualidades da práxis crítica se afirmam como elementos internalizados e propiciam, ao sujeito em ação, a libertação de aspectos relativos à práxis comum, tornando-o capaz de ler criticamente a prática social em que vive. (ARNONI, 2003, p. 4-5).
\end{abstract}

Compartilhando das idéias de Manzochi (et al., 1995), trabalhamos com uma perspectiva de educação emancipatória, que não se resume ao acúmulo de informações, mas que busca dar aos educandos condições de acesso a diferentes visões de mundo em uma perspectiva de participação, emancipação e pensamento crítico. Para Silva:

\footnotetext{
o pensamento crítico se apresenta como condição para o diálogo e, ao mesmo tempo, o diálogo aparece como único capaz de gerar o pensamento crítico promovendo a comunicação e a verdadeira educação. É impossível pensar educação numa perspectiva libertadora sem pensar os modos concretos de garantir sua dialogicidade $^{12}$. (SILVA, 2006, p. 33).
}

$\mathrm{Na}$ perspectiva da totalidade, a educação procura superar a fragmentação do conhecimento, não se limitando apenas à transmissão de conteúdos culturais e onde buscar o acesso ao conhecimento, não significa conhecer todos os objetos, mas conhecer qualquer objeto. Para encaminhar uma solução para questões relativas aos aspectos da temática ambiental, o ser humano precisa ter uma visão de conjunto deles, visto que, é a partir da visão

\footnotetext{
${ }^{11}$ Práxis comum é a atividade humano-social, de caráter imediato, que compreende o mundo como fragmentado, em decorrência da independência dos fenômenos. Caracteriza-se como atividade prático-sensível e utilitária do homem, que permite a alienação e a exploração.

${ }^{12}$ Dialogicidade que segundo Paulo Freire está ancorada no tripé educador-educando-objeto do conhecimento e é capaz de permitir aos alunos agir e refletir sobre a ação pedagógica realizada, diferente de um refletir da mente do professor.
} 
de conjunto que se pode avaliar a dimensão de cada aspecto no quadro que a compõe. (Arnoni, 2003).

Segundo Kosik (1995) a totalidade concreta, não é tudo e nem é a busca do princípio fundador de tudo. Investigar dentro da concepção da totalidade concreta significa buscar explicitar, de um objeto de pesquisa delimitado, as múltiplas determinações e mediações históricas que o constituem. A historicidade dos fatos sociais consiste fundamentalmente na explicitação da multiplicidade de determinações fundamentais e secundárias que os produz.

Se as atividades forem bem organizadas e bem desenvolvidas metodologicamente, a Educação Ambiental poderá ser capaz de transitar entre os múltiplos saberes populares e tradicionais, além dos científicos, o que alargaria a visão de ambiente do educando e ao superar a prevalência do conhecimento científico sobre os outros saberes, acionaria-se uma nova produção de conhecimento, aproximando-se daquilo que o sociólogo Boaventura de Sousa Santos chama de conhecimentos híbridos.

Trata-se de convidar a escola para aventurar-se a transitar entre os mais diferentes saberes e áreas disciplinares, rumo a novos modos de compreender, ensinar e aprender, num trabalho interdisciplinar onde, segundo Bittencourt (1996, p. 12-16), "cada disciplina escolar deve procurar estabelecer relação entre seus conteúdos e as questões que o tema ambiental coloca". Ainda de acordo com a autora, "não se realiza a contento um projeto de Educação Ambiental sem a contribuição integrada dos vários campos do conhecimento e das respectivas metodologias".

Nesse sentido, o trabalho com práticas de Educação Ambiental se mostra essencialmente interdisciplinar. Para Leff (2002), a interdisciplinaridade surge como uma necessidade prática de articulação dos conhecimentos, mas constitui um dos efeitos ideológicos mais importantes sobre o atual desenvolvimento das ciências, justamente por apresentar-se como o fundamento de uma articulação teórica. Frigotto (1995) de forma mais ampla coloca que a questão da interdisciplinaridade deve ser apreendida como uma necessidade e como problema fundamentalmente no plano material histórico-cultural e no plano epistemológico.

Assim, com base no que acreditamos e apresentamos até o presente momento, esta proposta de pesquisa tem como objetivo geral analisar o desenvolvimento de práticas de Educação Ambiental como forma de compreender sua organização, fundamentação teórica e metodológica nas práticas pedagógicas de professoras de $3^{\mathrm{a}}$ e $4^{\mathrm{a}}$ série do Ensino Fundamental da Diretoria de Ensino Centro Sul na cidade de São Paulo. 
Desta forma, esta pesquisa procura analisar os aspectos sociais, políticos e metodológicos das práticas de Educação Ambiental para que possam estimular a reflexão de outras práticas e em outras realidades. Para isso, com os objetivos específicos pretende-se:

- analisar a metodologia de ensino desenvolvida nas atividades de Educação Ambiental, relacionando-as com as Atividades Orientadoras de Ensino, buscando compreender os pontos de divergência e/ou convergência existentes entre elas;

- compreender as formas de organização das atividades de ensino de Educação Ambiental, buscando identificar os elementos intervenientes no processo e as relações disciplinares e interdisciplinares existentes;

- discutir referenciais teóricos que embasam o estudo das atividades de ensino, relacionando-as com as práticas pedagógicas dos professores integrantes do universo investigado;

- avaliar os avanços que os professores demonstram numa atividade prática.

Segundo o PCN (1997, p. 24), “a educação sozinha não é suficiente para mudar os rumos do planeta, mas certamente é condição necessária para tanto". 


\section{CAPÍTULO I}

\section{A EDUCAÇÃO AMBIENTAL COMO ATIVIDADE HUMANA}

"A liberdade reside na possibilidade de se buscar novos caminhos. Não importa onde eles possam nos levar; a satisfação e o aprendizado estão no próprio caminhar...”.

Lisboa

\section{EDUCAÇÃO AMBIENTAL E A CRISE ECOLÓGICA ATUAL: FUNDAMENTOS FILOSÓFICOS.}

Segundo Leff (2002), a problemática ambiental surgiu nas últimas décadas do século $\mathrm{XX}$, como uma crise de civilização, questionando a racionalidade econômica e tecnológica dominantes. Para o autor, essa crise tem sido explicada a partir de uma grande diversidade de perspectivas ideológicas, na qual, por um lado, ela pode ser explicada e percebida como a pressão exercida pelo crescimento da população sobre os limitados recursos do planeta e de outro, como o efeito da acumulação de capital e a maximização das taxas de lucro a curto prazo.

Sua gênese, dá-se num processo histórico dominado pela expansão do modo de produção capitalista, pelos padrões tecnológicos gerados por uma racionalidade econômica guiada pelo propósito de maximizar os lucros e os excedentes econômicos a curto prazo, numa ordem econômica mundial marcada pela desigualdade entre nações e classes sociais. Assim segundo Leff (2002), a problemática ambiental não é ideologicamente neutra e nem alheia a interesses econômicos e sociais.

Para Soffiati (1987) essa crise tem raízes muito antigas e profundas, já esboçada nos fundamentos de desigualdade entre cultura-natureza, localizando na obra de René Descartes ${ }^{13}$ o marco na história para essas raízes. Segundo Thomas (1988) na origem da ciência moderna, cujo propósito do conhecimento era a dominação, Descartes igualou os animais às máquinas fundamentando a subordinação da natureza pelo homem.

Essa separação homem e natureza aparece claramente justificada no modelo técnicoindustrial alicerçado pelo pensamento moderno e na Revolução Industrial que pode ser considerada o marco principal no processo de agravamento da degradação ambiental, representando a tradição mais fiel da hegemonia da produção em detrimento da conservação

\footnotetext{
${ }^{13}$ DESCARTES, René. Discurso sobre o método, 1637.
} 
dos recursos naturais, ou seja, da hegemonia humana na natureza, sendo esta considerada uma fonte inesgotável de recursos para sustentar a riqueza da sociedade (SEGURA, 2001).

Serres (1990), ao analisar o contrato social ${ }^{14}$, marco fundador da sociedade, destaca que a natureza ficou fora da esfera de preocupação, sendo reduzida à natureza humana; uma natureza concebida sem sujeito, domesticada e subordinada aos desígnios da humanidade. $\mathrm{O}$ homem passa a ter direito sobre a natureza e ao mesmo tempo em que a domina, domina também outros homens, os quais foram sendo transformados em coisas. Ainda de acordo com o autor, foi desaprendido a pensar conforme o tempo dos processos naturais a longo prazo e a sociedade passou a imprimir transformações no mundo sem considerar as escalas de grandeza e complexidade merecidas, desencadeando os desequilíbrios que hoje comprometem a própria vida humana.

Uma das principais causas da problemática ambiental foi atribuída à ciência moderna e à Revolução industrial, que fizeram a distinção das ciências, o fracionamento do conhecimento e a compartimentalização da realidade em campos disciplinares confinados. Assim, iniciou-se uma busca por um método que fosse capaz de reintegrar esses conhecimentos dispersos num campo unificador do saber; um projeto para pensar as condições teóricas e para estabelecer práticas de interdisciplinaridade.

Observa-se que essa crise ambiental e civilizatória, problematiza os paradigmas estabelecidos do conhecimento e demanda novas metodologias capazes de orientar um processo de reconstrução do saber que permita realizar uma análise integrada da realidade, ou seja, "pretende-se explicar e resolver a problemática ambiental, por meio de uma análise funcional da sociedade, inserida como um subsistema dentro do ecossistema global do planeta" (LEFF, 2002, p. 67).

Dessa forma, a crise ecológica que vivemos nos dias de hoje, não deve ser encarada como mais uma crise pela qual passa a humanidade, mas como uma situação limite para a sobrevivência sadia das futuras gerações e em especial do planeta.

Segundo Segura (2001, p. 32), “a mundialização dos efeitos da degradação (ambiental), resultado da própria globalização econômica e cultural, gerou um movimento favorável em relação à consciência ecológica global nos últimos 30 anos, mas ainda prevalece a fragilidade de qualquer iniciativa que questione o modelo dominante".

\footnotetext{
${ }^{14}$ Segundo Segura (2001, p.32), o conceito de contrato social foi desenvolvido pelo filósofo Thomas Hobbes, em 1651, na obra Leviatã, que em linhas gerais traduz a idéia de que os indivíduos vivem em conflito permanente e por meio de um pacto, renunciam ao seu poder natural e delegam poder ao Estado para que esse garanta a segurança a todos.
} 
A emergência da consciência ambiental ${ }^{15}$, trouxe à tona o sujeito da natureza, que é o próprio homem, conhecedor da razão e dos seus direitos e deveres de cidadão, protagonista da nova ordem global que busca a religação do ser humano com todos os componentes da natureza. Assim, é importante ter consciência da finitude humana e também das diversas possibilidades de ação no mundo; é a aliança entre a prudência e a razão que motiva para um constante devir (SERRES, 1990).

Temos que ter consciência ${ }^{16}$ que da mesma maneira que existem pessoas que lutam por justiça social e ambiental, que buscam melhores de condições de vida para todos, também existem aqueles que buscam o desenvolvimento a qualquer custo. Assim no plano prático, o problema é enfrentar os conflitos advindos da diversidade dos atores sociais e de seus interesses.

Em todo o histórico mais recente da crise ambiental, a educação e mais especificamente a Educação Ambiental, tem sido lembrada como um instrumento capaz de responder positivamente a essa problemática ao lado de outros meios políticos, econômicos, sociais, éticos, científicos e técnicos (LIMA, 2002).

Uma das principais conclusões e proposições assumidas em reuniões internacionais ${ }^{17}$ é a recomendação de se investir numa mudança de mentalidade, conscientizando as sociedades, para a necessidade de se adotarem novos pontos de vista e novas posturas diante dos dilemas e das constatações feitas. Assim surge a Educação Ambiental, como um meio indispensável para se conseguir criar e aplicar formas cada vez mais sustentáveis ${ }^{18}$ de interação sociedadenatureza (BRASIL, 1997). No Brasil, a Educação Ambiental cresceu e se tornou mais conhecida principalmente nas décadas de 80 e 90 com o avanço da consciência ambiental.

Sobre o esforço da Educação Ambiental a partir dos anos 70 de responder à crise, Lima afirma que:

\footnotetext{
${ }^{15}$ Consciência de perceber-se como sujeito diretamente relacionado com o atual quadro de degradação pela qual passa o planeta, da finitude dos recursos naturais e de reconhecer-se como um agente capaz de realizar ações que minimizem ou eliminem os problemas ambientais.

${ }^{16}$ Consciência aqui entendida como o movimento dialético entre o desvelamento crítico da realidade e a ação social transformadora, segundo o princípio de que os seres humanos se educam reciprocamente e mediados pelo mundo - Paulo Freire (1983), Pedagogia do Oprimido.

${ }^{17}$ I Conferência Internacional sobre Meio Ambiente, realizada em 1972 em Estocolmo, Suécia; Encontro de Educação Ambiental em Belgrado, em 1975; I Conferência sobre Educação Ambiental, em 1977 em Tbilisi, dentre outras. (DIAS, 2001, p. 35-40).

${ }^{18}$ Compartilhando das idéias de Jacobi (2005) observamos que o conceito de "Desenvolvimento Sustentável", "Sociedade Sustentável" ou de "Sustentabilidade" tem se convertido num conceito plural, existem várias concepções para "desenvolvimento" como para "sutentabilidade". Mas de modo abrangente, a noção de "Desenvolvimento Sustentável" remete para a necessidade de se redefinir as relações entre sociedade e natureza, ou seja, uma mudança no próprio processo civilizatório". Ainda de acordo com a Comissão Mundial sobre Meio Ambiente e Desenvolvimento (CMMAD) da Organização das Nações Unidas, Desenvolvimento Sustentável é aquele que atende às necessidades presentes sem comprometer a possibilidade de que as gerações futuras satisfaçam as suas próprias necessidades.
} 
... ou a EA é política e transformadora da realidade socioambiental ou não é coisa alguma. Se esse reconhecimento da natureza política da EA não é capaz de ultrapassar o nível da retórica, se o medo da mudança for maior que o desafio de inovar, então podemos apagar as luzes e procurar desafios mais sérios com que nos ocupar, posto que se a EA não tem compromisso com a transformação social e individual, ela converte-se em mero artifício para justificar, legitimar e conservar a exploração e a degradação - do homem e da natureza - praticadas pelo sistema capitalista (LIMA, 2002, p.132).

De acordo com Sorrentino (2005), o meio ambiente como política pública não pontual surgiu no Brasil após a Conferência de Estocolmo, em 1972 quando foi criada a Secretaria Especial de Meio Ambiente (SEMA), mas apenas após 1977 a Educação Ambiental foi introduzida como estratégia para conduzir à sustentabilidade ambiental e social.

Segundo Leff, para se poder implantar políticas ambientais eficazes:

é necessário reconhecer os efeitos dos processos econômicos atuais sobre a dinâmica dos ecossistemas. É preciso avaliar as condições ideológicas, políticas, institucionais e tecnológicas que determinam a conservação e regeneração dos recursos de uma região, os modos de ocupação de território, as formas de apropriação e usufruto dos recursos naturais e de divisão de suas riquezas, bem como o grau e as maneiras de participação comunitária na gestão social de suas atividades produtiva (LEFF, 2002, p. 68).

Ainda sobre a questão de se politizar a Educação Ambiental, acrescentamos que esta comporta múltiplos elementos inter-relacionados: primeiro, a de desenvolver a consciência essencial de que a questão ambiental se origina e se expressa no conflito entre interesses privados e públicos pelo acesso e pela apropriação dos recursos naturais, relacionando assim, a origem desses conflitos aos principais agentes socioeconômicos responsáveis pela degradação socioambiental; segundo, desenvolver a noção de qualidade de vida ${ }^{19}$ e a compreensão da importância de se trabalhar pela qualidade da própria vida, estimulando sua redistribuição para aqueles que ainda não têm e defendendo a expansão da qualidade de vida para aqueles que já a conquistaram de certa forma. Resumindo, politizar a questão e a Educação Ambiental supõe considerar o educando como portador de direitos e deveres,

\footnotetext{
${ }^{19}$ Segundo Herculano (2000), "qualidade de vida" pode ser definida como a soma das condições econômicas, ambientais, científico-culturais e políticas coletivamente construídas e postas à disposição dos indivíduos para que estes possam realizar suas potencialidades.
} 
abordando o meio ambiente como um bem público de acesso saudável e como um direito de cidadania (LIMA, 2002).

Sair da crise hoje é um desafio mundial que cada vez mais vem mobilizando importantes organizações e os governantes de grandes nações. Propostas alternativas de desenvolvimento, que superem não só as desigualdades e injustiças materiais, mas também as sociais e ambientais, precisam ser buscadas cada vez mais pelo conjunto da sociedade.

Para Serres (1990), se não houver um esforço coletivo para a modificação da "poluição cultural" da racionalidade dominante, não haverá derrota da "poluição cultural", pois as duas estão profundamente ligadas e assim o fortalecimento de uma consciência planetária sobre os riscos ambientais depende também de transformações estruturais nas relações humanas.

Mazzotti ao analisar as representações sociais sobre problema ambiental de diversos grupos sociais afirma que:

o problema ambiental é visto como um desequilíbrio produzido pelo estilo de vida da sociedade moderna. As razões para o desequilíbrio seriam de duas ordens gerais: o tipo de desenvolvimento econômico e o tipo de racionalidade envolvida cartesiana, particularista. Dessa maneira, seria necessária a construção de outro estilo de vida e de uma nova racionalidade. Esta nova racionalidade seria holística e implicaria uma nova ética de respeito à diversidade biológica cultural, que estaria na base da sociedade sustentável. A ênfase das ações educativas justifica-se pela necessidade de formar um novo homem, aquele que seria capaz de viver em harmonia com a natureza (MAZZOTTI, 1997, p. 106).

Para a real transformação do quadro de crise estrutural e conjuntural em que vivemos hoje, a Educação Ambiental é o elemento estratégico na formação de ampla consciência crítica das relações sociais e de produção que situam a inserção humana na natureza.

A epistemologia ambiental, mais do que um projeto com a finalidade de apreender um objeto de conhecimento, é um trajeto para chegar a saber o que é o ambiente, que não é ecologia, mas a complexidade do mundo. Parte de um esforço por pensar a articulação de ciências capazes de gerar um método e um pensamento integrador do real, para desembocar num saber que vai além do conhecimento científico, para problematizar a racionalidade modernizadora que provoca a crise ambiental (LEFF, 2002). 


\section{A EDUCAÇÃO AMBIENTAL E A SOCIEDADE DE RISCO.}

Vivemos hoje em uma sociedade marcada por profundas transformações nas relações sociais e nos modos de produção, ocasionadas pelo processo de industrialização. Não se previu que essas transformações pudessem ter um efeito destrutivo tão grande como estão tendo, principalmente em relação ao meio ambiente. Com isso, preocupações ecológicas, que não tinham muito espaço nas tradições de pensamento, passaram a fazer parte do discurso em nossa sociedade contemporânea. Um mundo carregado e perigoso, no qual o risco não é apenas uma questão de ação individual mas também coletiva, pois existem espaços que afetam a sociedade como um todo, constituindo assim os "ambientes de risco" (GIDDENS, 1991).

Para Beck (1997), a sociedade de risco não é uma opção que se pode escolher ou rejeitar no decorrer de disputas políticas. Ela surge na continuidade dos processos de modernização autônoma, ou seja, a sociedade industrial transforma-se em sociedade de risco que se sustenta em um tripé: esgotamento dos recursos naturais em função do modelo industrial; insegurança constante e individualização em virtude do desencanto com o coletivo.

Os riscos estão diretamente relacionados com a modernidade e ainda com os imprevisíveis efeitos da globalização, como uma radicalização dos efeitos da modernidade. Assim o progresso gerado pelo desenvolvimento das ciências e tecnologia, passa a ser considerado como fonte potencial de autodestruição da sociedade industrial, a partir do qual se produzem, por sua vez, novos riscos, de caráter global, afetando o planeta e atravessando fronteiras nacionais e de classes (GUIVANT, 1998).

Para Noal (2002), a expressão "risco" é recente, mas a idéia paradigmática já foi desenvolvida há bastante tempo. Além de Heidegger, Marx desenvolveu a "teoria da crise", Durkheim utilizou em seus estudos sobre o suicídio o termo "anomia" e, posteriormente, Prigogine mencionou a expressão "indivíduo perigoso"; conceitos esses presentes nessa fase de desenvolvimento da sociedade em que o controle dos riscos econômicos, sociais e políticos passam da defesa das instituições para a da sociedade das corporações.

Segundo Jacobi (2005), vive-se no início do século XXI, uma emergência que, mais que ecológica, é uma crise do estilo de pensamento e do conhecimento que sustentaram a modernidade.

A sociedade moderna produz simultaneamente riqueza e riscos que por sua vez são distribuídos desigualmente e também, igualou e desigualou o consumo e os riscos, gerando um verdadeiro paradoxo. Igualou porque os riscos produzidos afetam as mais diferentes 
classes sociais como um efeito boomerang, isto é, quem agride, de uma forma ou de outra, é afetado pelo efeito da agressão, e desigualou, uma vez que certos riscos atingem mais dramaticamente as classes sociais menos favorecidas por vários motivos: menos chances de reivindicar mudanças, menos condições de identificar os riscos por falta de informação ou ainda porque têm mais dificuldades para acessar os canais de participação nos processos decisórios (SEGURA, 2001).

A problemática sócioambiental está articulada à gênese do processo de globalização e também à discussão atual da sociedade de riscos. Para Spink (1999, p.11), "a ecologia é indubitavelmente um fenômeno da sociedade de risco: ela nos fala de riscos que - como é próprio dos fenômenos da modernidade - tendem à globalização".

A essência da crise ambiental é a incerteza, e isto terá maior ou menor impacto de acordo com a forma como a sociedade levanta a questão da auto-limitação do desenvolvimento (BECK, 1997).

Santos reflete sobre a questão relacionada aos problemas ambientais considerando que ela perpassa todos os países do planeta de forma semelhante, porém com algumas especificidades, o que a torna transnascionalizada:

\footnotetext{
De todos os problemas enfrentados pelo sistema mundial, a degradação ambiental é talvez o mais intrinsecamente transnacional e, portanto, aquele que, consoante o modo como for enfrentado, tanto pode redundar o conflito global entre o norte e o sul, como pode ser plataforma para o exercício de solidariedade transnacional e intergeracional (SANTOS, 1996, p. 296).
}

Acredita-se, que a sociedade de risco é mais autocrítica e pode se politizar, à medida que é capaz de perceber as agressões cada vez mais intensas e tornar público o debate sobre elas. Assim Beck (1994) desenvolve o conceito de modernização reflexiva, que significa, em linhas gerais, a autocrítica diante dos riscos, o questionamento das conseqüências da modernização, conduzindo ao processo de mudanças nas diretrizes político-institucionais. Nesse sentido, trabalha com a hipótese de mobilização dos atores sociais, a partir da consciência advinda da percepção dos riscos e conseqüentemente, da responsabilização coletiva em relação a eles (reflexo-reflexão).

Segundo Leff (2003), a complexidade reflexiva é capaz de oferecer explicações aos fenômenos de grande escala e às hegemonias que têm sido vividas em longos períodos dentro da espécie humana. 
Os riscos contemporâneos explicitam os limites e as conseqüências das práticas sociais, trazendo consigo um novo elemento, a reflexividade, onde a sociedade, produtora de riscos, torna-se crescentemente reflexiva, o quê quer dizer que ela se torna um tema e um problema para si própria. A sociedade torna-se cada vez mais auto-crítica e, ao mesmo tempo em que a humanidade põe a si em perigo, reconhece os riscos que produz e reage diante disso (BECK, 1997).

A reflexividade da vida social moderna consiste no fato de que as práticas sociais são constantemente examinadas e reformadas à luz de informação renovada sobre estas próprias práticas, alterando assim constitutivamente seu caráter.

A partir disso, segundo Morin (1994), problemas como destruição ambiental, fanatismo, racismo e fome podem possibilitar na sociedade moderna o afloramento de uma consciência ambiental e ainda um comprometimento social em relação à construção de uma nova sociedade com a percepção dos riscos e da finitude dos recursos naturais (BECK, 1996).

O debate contemporâneo em torno dos elementos que caracterizam situações de risco e incertezas ainda se limita a alguns países, universidades e autores, mas observa que o universo dessas discussões tem aumentado gradativamente nos últimos anos, representando um avanço em direção à compreensão do processo de decadência da sociedade.

Neste sentido, para Buarque (1990) os riscos criados pela civilização, e que se apresentam à humanidade, restituem ao homem a aventura de retomar seu destino e controlálo e assim, o que ele antes fazia temendo aos deuses, aos quais já não teme, agora terá que fazer diante dos riscos que criou, tendo que enfrentar um deus maluco chamado "Homem" e uma praga chamada poder científico e tecnológico.

Com isso, busca-se caminhar no sentido de um projeto civilizatório que leve em conta as limitações dos recursos naturais e do modelo tecno-industrial tal como está implantado em escala mundial, no qual a combinação entre o reflexo (percepção) diante da ameaça e a reflexão (evolução da consciência) possibilitem a materialização de uma transformação. Transformação esta que, para ocorrer, segundo Beck (1994), sob o ponto de vista político, faz-se necessário repensar a engenharia institucional, ou seja; quem articula, como se articulam as mudanças e ainda quem são os atores sociais responsáveis pela tomada de decisões.

Na sociedade brasileira, o debate sobre as questões ambientais ainda é bastante restrito se comparado a outros países, dada a imensa desigualdade de acesso à educação e informação, mas não se pode desconsiderar o esforço de participação e iniciativas voltadas para a formação de agentes sociais comprometidos com um ideal de sociedade sustentável. Assim, o 
grande desafio está na necessidade de construir o "nós", a fim de superar o "eu" desmobilizado (BECK, 1994).

Jacobi (2003) observa a necessidade de se aprimorar os meios e o acesso à informação, e de o poder público intervir nos processos educacionais buscando caminhos possíveis para alterar o quadro atual de degradação ambiental. Dessa forma, trata-se de promover o crescimento de uma sensibilidade maior nas pessoas em relação aos problemas ambientais, como forma de fortalecer sua co-responsabilidade na fiscalização e no controle da degradação ambiental.

A desinformação, a falta de consciência ambiental e o déficit de práticas comunitárias baseadas na participação e no envolvimento dos cidadãos acabam gerando posturas de dependência e de não responsabilidade das pessoas. Nesse contexto, acreditamos que as práticas educacionais devem apontar para propostas pedagógicas centradas na mudança de hábitos, no desenvolvimento de um pensamento crítico e de um fazer coletivo e solidário para a resolução dos problemas locais e globais, desenvolvendo competências e habilidades, participação e capacidade de avaliação nos educandos. Para Morin (2003), isto desafia a sociedade a elaborar novas epistemologias que possibilitem o que ele denomina como uma reforma do pensamento.

Para autores como Morin, Capra e Leff uma mudança paradigmática implica mudança de percepção e de valores na formação das gerações atuais para não somente aceitar a incerteza e o futuro, mas para gerar um pensamento complexo e aberto às mudanças, à diversidade e à possibilidade de construir e reconstruir um processo de novas leituras, interpretações e novas ações.

Para Jacobi, a reflexão sobre a complexidade ambiental:

\footnotetext{
abre um estimulante espaço para compreender a gestação de novos atores sociais que se mobilizam para a apropriação da natureza, para um processo educativo articulado e compromissado com a sustentabilidade e a participação, apoiado numa lógica que privilegia o diálogo e a interdependência de diferentes áreas e saber. Mas também questiona valores e premissas que norteiam as práticas sociais prevalecentes, isto implicando uma mudança na forma de pensar, uma transformação no conhecimento e nas práticas educativas (JACOBI, 2005, p. 243).
}

Nesse sentido, acreditamos e defendemos as práticas escolares de Educação Ambiental que estimulem o diálogo, a solidariedade e a participação de todos na busca de um mundo mais justo e equilibrado. 
Segundo Santos (1996) somente a capacidade de poluição dos países do Sul pode ameaçar os países do Norte e dessa forma obter alguma concessão. Os impasses criados pelas situações de risco devem estimular novas práticas solidárias e conciliatórias na civilização, pois o potencial das relações que envolve a sociedade e meio ambiente ainda tem sido muito pouco utilizado no processo de formulação de políticas públicas. Com isso, percebe-se que são necessárias mudanças importantes no pensamento, nas atitudes e na ação decisória dos habitantes dos países do Sul, enquanto sociedade civil organizada. Mudanças essas oriundas principalmente de seus representantes políticos e administrativos. Nesse caso, o processo educativo tem um papel bastante importante para que essas mudanças ocorram, mas os países do Sul ainda são os que mais sofrem com a deficiência num sistema de ensino pouco consistente, pois está voltado para o conhecimento e para a transformação das contradições da sociedade mundial.

\section{SABER AMBIENTAL: CIDADANIA E INTERDISCIPLINARIDADE.}

Compartilhando das idéias de Jacobi (2000) a partir deste ponto da nossa reflexão, quando nos referirmos à Educação Ambiental, estaremos situando-a num contexto mais amplo que é o da "educação para a cidadania", que se configura como determinante para a consolidação de sujeitos cidadãos. A educação para a cidadania trata não só da capacidade do indivíduo de exercer os seus direitos nas escolhas e nas decisões políticas, mas de assegurar sua total dignidade nas estruturas sociais. Assim o exercício da cidadania implica autonomia e liberdade responsável, participação na esfera política democrática e na vida social.

Numa educação para a cidadania, o principal eixo de atuação deve buscar a solidariedade, a igualdade e o respeito à diferença por meio de formas democráticas de atuação baseadas em práticas interativas e dialógicas.

Segundo Loureiro (2002) o conceito de cidadania pode ser assumido como algo que se constrói diariamente, que se constitui ao dar significado ao pertencimento do indivíduo a uma sociedade em cada fase histórica e não como algo que possui uma origem divina, natural ou que seja fornecida por governantes. Nessa perspectiva, para Coutinho, cidadania é:

... a capacidade conquistada por alguns indivíduos, ou (no caso de uma democracia efetiva) por todos indivíduos, de se apropriarem dos bens socialmente criados, de atualizarem todas as potencialidades de realização humanas abertas pela vida social em cada contexto historicamente determinado" (COUTINHO, 1997, p. 146). 
No espaço da escola, a educação para a cidadania pretende sensibilizar alunos e professores para uma participação mais consciente no contexto da sociedade, questionando comportamentos, atitudes e valores, além de propor novas práticas que busquem uma transversalidade de saberes, um novo modo de pensar, pesquisar e elaborar conhecimento, que possibilitem integrar teoria e prática.

Através da educação escolar e aqui especificamente da Educação Ambiental, o exercício da cidadania é concebido como uma prática que tem a possibilidade de criar condições para que os alunos desenvolvam suas capacidades e aprendam conteúdos necessários para construir instrumentos de compreensão da realidade e de participação em relações sociais, políticas e culturais diversificadas e cada vez mais amplas, ou seja, como uma prática que permita o acesso de todos à totalidade dos recursos culturais relevantes para a intervenção e a participação responsável na vida social (BRASIL, 1997a).

A Educação Ambiental está longe de ser uma atividade tranqüilamente aceita e desenvolvida, pois ela implica em mudanças profundas, principalmente nos modos de pensar e agir já consolidados pela modernidade, mas que quando é bem realizada, ela pode levar a mudanças de comportamento, atitudes e principalmente valores de cidadania que podem ter fortes conseqüências sociais. Assim, "a principal função do trabalho com o tema Meio Ambiente, é o de contribuir para a formação de cidadãos conscientes, aptos para decidirem e atuarem na realidade socioambiental de modo comprometido com a vida, com o bem-estar de cada um e da sociedade local e global” (BRASIL, 1997, p. 29).

As palavras e conceitos "sociedade, meio ambiente, cidadania e educação" são empregadas atualmente à exaustão, e segundo um provérbio chinês, quando utilizamos muito uma mesma palavra, aquilo que ela nomeia mostra-se escasso ou inexistente. Dessa forma, não alcançamos níveis satisfatórios de organização na sociedade. No Brasil, em particular, os elementos responsáveis pelo equilíbrio ambiental apresentam-se extremamente vulneráveis, principalmente por uma educação que de maneira geral, enfrenta problemas acentuados de qualidade e que ainda não alcançou patamares desejáveis de democratização. "Se a cidadania na sua expressão clássica, ainda engatinha, a ecocidadania ${ }^{20}$ continua revestida de um caráter utópico e distante" (SOFFIATI, 2002, p. 23-24).

\footnotetext{
${ }^{20}$ Segundo Loureiro, "ecocidadania é um conceito consensualmente utilizado para expressar e inserção de uma nova ética - a ecológica - e seus desdobramentos na vida diária, em um contexto que, de modo crescente, possibilita a tomada de consciência individual e coletiva das responsabilidades, tanto locais e comunitárias quanto globais. Nesse conceito, amplia-se o sentimento de pertencimento à humanidade e a um planeta único, comumente identificado com a noção de cidadania planetária ou cosmopolita” (LOUREIRO, 2002, p. 29).
} 
Com relação à palavra cidadania em específico, acordo com Ferreira (1993), existem algumas dificuldades para sua conceituação em virtude de representações que nem sempre correspondem a postulados rigorosos, ou a modos diversos de tratamento; assim, ora ela é tratada como nacionalidade, ora refere-se ao aspecto da vida social (relacionada a juízos de valor). Dessa forma, a noção de cidadania não pode ser qualificada apenas em nível de direitos e deveres dos cidadãos, mas também em seus aspectos psicossociais.

A escola, por intermédio da cooperação e do fortalecimento da construção de uma participação autônoma, crítica e reflexiva, poderá constituir um sujeito capaz de exercer sua cidadania, que é um pressuposto básico da Educação Ambiental.

Nesse processo, os educadores devem estar cada vez mais preparados para reelaborar as informações que recebem principalmente, as ambientais, para poder transmitir e decodificar para aos alunos a expressão dos significados em torno do meio ambiente e da ecologia nas suas múltiplas determinações e intersecções, uma vez que se o discurso ambiental for dissociado das condições sócio-históricas, ele pode ser alienante e levar ao desenvolvimento de posturas conservadoras. Dessa forma, o papel dos professores é essencial para impulsionar as transformações de uma educação que assuma um compromisso com o desenvolvimento sustentável e com as futuras gerações ou ainda, de impulsionar as transformações de uma educação que assume um compromisso com a formação de uma visão crítica, de valores éticos para a transformação de uma sociedade ambiental.

Acreditamos que a inserção de uma Educação Ambiental numa perspectiva crítica, reflexiva e emancipatória ${ }^{21}$, capaz de desenvolver práticas que articulem a educação e o meio ambiente, só ocorrerão na medida em que o professor também assumir uma postura crítica, reflexiva e emancipatória.

Para Tristão (2002) existem quatro desafios da Educação Ambiental que, entrelaçados, estão associados ao papel do educador na contemporaneidade. O primeiro, refere-se ao "enfrentamento da multiplicidade de visões", o que implica na preparação do educador para fazer conexões. O segundo, refere-se à "superação da visão do especialista", que implica na ruptura das práticas disciplinares. O terceiro, na "superação da pedagogia das certezas", com a formação de um professor reflexivo e o quarto desafio, a superação da lógica da exclusão e das desigualdades sociais. Com isso, observamos a necessidade de se consolidar práticas pedagógicas que estimulem a interdisciplinaridade.

\footnotetext{
${ }^{21}$ Idéia utilizada por Boaventura que expressa o produto da iniciativa humana, o qual implica recuperar a capacidade de espanto e de indignação e a produção de subjetividade inconformistas e rebeldes.
} 
Nossa argumentação vai no sentido de reforçar que as práticas educativas articuladas com a problemática da Educação Ambiental devem ser vistas como parte componente de um processo educativo orientado para refletir a Educação Ambiental no contexto de crise ambiental, de crescente insegurança e incerteza face aos riscos produzidos pela sociedade.

A abordagem do meio ambiente na escola passa a ter um papel articulador dos conhecimentos nas diversas disciplinas, num contexto no qual os conteúdos são ressignificados. Assim, a Educação Ambiental assume a forma de um processo intelectual ativo, enquanto aprendizado social, baseado no diálogo e na interação com constante processo de recriação e reinterpretação de informações, conceitos e significados, que se organizam em sala de aula ou na experiência pessoal do aluno, promovendo os instrumentos para a construção de uma visão crítica, reforçando práticas que explicitam a necessidade de discutir e agir em relação aos problemas socioambientais.

Nesse processo de recriação e reinterpretação baseado no diálogo, na organização de conceitos e significados, destacamos a questão da especificidade de cada disciplina. Para Leff, a especificidade de cada disciplina:

... é importante para o diagnóstico de uma problemática concreta, mas adquire maior relevância quando sua resolução torna necessária a "tradução" num programa multidisciplinar de pesquisas, capaz de gerar os conhecimentos necessários para implementar formas alternativas de aproveitamento sustentável dos recursos naturais. Nesse momento, cada especialista remete-se a conhecimentos, métodos e instrumentos de suas disciplinas, a suas técnicas de laboratório e a seus campos de experimentação, para produzir explicações científicas e inovações tecnológicas concretas (LEFF, 2002, p. 97).

Assim, nessa perspectiva, as práticas interdisciplinares são concebidas como um processo de conhecimento que busca estabelecer cortes transversais na compreensão e explicação do contexto de ensino e pesquisa, buscando a interação entre as disciplinas e superando a compartimentalização científica pela excessiva especialização e não apenas como a justaposição das várias disciplinas.

As mudanças ambientais globais revolucionaram os métodos de pesquisa e as teorias científicas para poder apreender uma realidade em via de complexização que ultrapassa a capacidade de compreensão e explicação dos paradigmas teóricos estabelecidos. Dessa forma, a problemática ambiental propõe a necessidade de internalizar um saber ambiental emergente em todo um conjunto de disciplinas para construir um saber e uma racionalidade social 
orientados para os objetivos de um desenvolvimento sustentável, eqüitativo e duradouro (Leff, 2002).

Nas questões ambientais, a ênfase nas práticas interdisciplinares deve-se à constatação de que os problemas que afetam e mantêm a vida no nosso planeta são de natureza global e que a compreensão de suas causas não pode restringir-se apenas à dimensão e aos fatores estritamente biológicos, mas também aos políticos, econômicos, sociais e culturais, apoiandose em trocas sistemáticas e no confronto de saberes disciplinares que incluam não apenas uma problemática nas interfaces entre as ciências naturais e sociais, mas com uma ação orgânica das diversas disciplinas que supere a visão multidisciplinar (JACOBI, 2005).

Muito se tem discutido sobre a interdisciplinaridade por especialistas das mais diferentes áreas, mas não há uma conceituação única para esse termo. Para Leff:

a interdisciplinaridade é proclamada hoje em dia não só como método e prática para a produção de conhecimentos e para sua integração operativa na explicação e resolução dos cada vez mais complexos problemas do desenvolvimento, mas surge como a pretensão de promover intercâmbios teóricos entre as ciências e de fundar novos objetos científicos. Entretanto, a interdisciplinaridade teórica - entendida como a construção de um "novo objeto científico" a partir da colaboração de diversas disciplinas, e não apenas como tratamento comum de uma temática - é um processo que se consumou em poucos casos da história das ciências (LEFF, 2002, p. 70).

Diferentemente dos conceitos de multidisciplinaridade ${ }^{22}$ e $\operatorname{transdisciplinaridade~}^{23}$, a interdisciplinaridade não se prende a unificação dos saberes, mas deseja um espaço de troca e articulação entre os diferentes conhecimentos e saberes, onde as disciplinas possam estabelecer conexões entre si, na construção de novos referenciais conceituais e metodológicos, promovendo a troca de conhecimento e o diálogo dos saberes especializados com os saberes não científicos (CARVALHO, 2004).

No PCN Meio Ambiente e Saúde, a orientação é de se integrar os conteúdos de Meio Ambiente ao currículo através da transversalidade, uma vez que eles deverão ser tratados nas diversas áreas do conhecimento criando assim uma visão global e abrangente da questão ambiental (BRASIL, 1997).

22 Conceito que "diz respeito à situação em que diversas disciplinas, com base em seu quadro teóricometodológico, colaboram no estudo ou tratamento de dado fenômeno" (CARVALHO, 2004, p. 121).

23 "Radicaliza a idéia de reacomodação e unificação dos conhecimentos disciplinares, com relativo desaparecimento de cada disciplina" (CARVALHO, 2004, p. 121). 
Como os problemas ambientais ultrapassam a especialização do saber, para intervir nos riscos ambientais ou para gerir o ambiente, de modo que tais riscos sejam evitados, é preciso compreender os complexos processos biológicos, geográficos, históricos, econômicos e sociais gerados. Por isso, as equipes que estudam as questões ambientais e intervêm nelas são, em sua maioria, compostas de profissionais de várias áreas do conhecimento que atuam em conjunto e buscam formas interdisciplinares de cooperação entre si e de compreensão da realidade.

De acordo com a Política Nacional de Educação Ambiental (PNEA) ${ }^{24}$, a visão interdisciplinar na Educação Ambiental aparece na orientação de "estar presente de forma articulada, em todos os níveis e modalidade do processo educativo, em caráter formal e nãoformal".

Para González-Gaudiano (2005) a busca da interdisciplinaridade caracterizou alguns dos principais debates sobre a educação durante grande parte da segunda metade do século XX. Interdisciplinaridade esta, que dentre suas muitas possibilidades de compreensão, pode ser entendida segundo o autor como uma proposta epistemológica que tende a superar a excessiva especialização disciplinar surgida da racionalidade científica moderna ou ainda como a busca de novos sentidos do conhecimento que as disciplinas parcelares não estão em condições de proporcionar.

$\mathrm{Na}$ realização da Conferência Intergovernamental sobre Educação Ambiental, realizada em Tbilisi em 1977, a Educação Ambiental é citada não como uma matéria suplementar que se soma aos programas existentes, mas como o resultado de uma reorientação e articulação entre as diversas disciplinas e experiências educativas que facilita a percepção integrada do meio ambiente para que seja compreendida a complexidade dos problemas ambientais e reformuladas as suas soluções (UNESCO, 1980).

Nesse contexto das práticas interdisciplinares, a Educação Ambiental aponta para a necessidade de elaboração de propostas pedagógicas centradas na conscientização, mudança de atitude e práticas sociais, desenvolvimento de conhecimentos, capacidade de avaliação e participação dos educandos, ou seja, práticas que permitam que os educandos adquiram uma base adequada de compreensão dos problemas e dos riscos socioambientais, do seu impacto no meio ambiente global e local, da interdependência dos problemas e da necessidade de cooperação e diálogo entre disciplinas e saberes.

${ }^{24}$ Lei no ${ }^{\circ}$ 9.795, de 27 de Abril de 1999, artigo 2º IN: DIAS, Genebaldo Freire. Educação Ambiental: princípios e práticas. $7^{\mathrm{a}}$ edição. São Paulo: Gaia, 2001, p. 202. 
Segundo Leff (2002) o pensar sobre o desenvolvimento de práticas interdisciplinares desenvolveu-se a partir do momento em que a crise ambiental passou a problematizar os paradigmas estabelecidos do conhecimento, o que acabou demandando novas metodologias capazes de orientar um processo de reconstrução do saber através de uma análise integradora da realidade; de um método capaz de reintegrar esses conhecimentos dispersos num campo unificado do saber.

A troca de idéias e informações que gera um processo interdisciplinar faz com que surjam perguntas a partir de uma especialidade para outras, ou seja, inquietações sobre o potencial aplicativo dos conhecimentos das disciplinas envolvidas, o que pode levar a formular problemas teóricos e práticos que não surgem do desenvolvimento interno dos paradigmas das ciências e do saber ambiental atual, induzindo assim, um desenvolvimento do conhecimento ambiental. Aqui, a eficácia do processo interdisciplinar é produto da integração dos saberes, habilidades, métodos e técnicas particulares das diferentes especialidades, orientadas para o estudo de certos problemas teórico-práticos específicos e a partir da definição de seus campos de aplicação (LEFF, 2005).

Segundo González-Gaudiano (2005), ainda de acordo com a Conferência de Tbilisi, os currículos devem ter um caráter interdisciplinar. Para tanto, essa Conferência apresentou quatro propostas para essa adequação, dentre as quais destacamos uma que diz que:

... a forma mais recomendável para introduzir o enfoque interdisciplinar é a técnica do projeto, que consiste em buscar diferentes soluções para problemas de higiene, de alimentação, de contaminação ou de organização de uma zona verde. Cada disciplina não impõe sua linguagem própria, mas contribui para a melhor compreensão dos problemas, e os professores das diferentes disciplinas intervêm a pedido dos grupos de alunos, apoiando-se em assessores externos, voltando-se para problemas específicos de sua comunidade e criando grupos de trabalho dedicados à análise e à ação (GONZÁLEZ-GAUDIANO, 2005, p. 125).

Apesar de muito se falar em trabalhos interdisciplinares, observamos ainda uma grande resistência por parte de alguns profissionais da educação em estar desenvolvendo tais práticas. Inúmeras são as justificativas, mas a verdade, é que a interdisciplinaridade jamais será uma posição ou realização fácil, cômoda ou estável, pois exige novas maneiras de conhecer o campo da produção de conhecimento buscada no contexto de uma mentalidade disciplinar. 
Frigotto (1995) destaca que apesar de vários estudos e análises sobre a questão da interdisciplinaridade, alguns aspectos não têm sido suficientemente enfatizados. Para o autor, a questão da interdisciplinaridade deve ser apreendida como uma "necessidade" - algo que historicamente se impõe como imperativo - e como "problema" - algo que se impõe como desafio a ser decifrado.

O caráter necessário do trabalho interdisciplinar na produção e na socialização do conhecimento no campo das ciências sociais e no campo educacional decorre da própria forma como o homem produz-se enquanto ser social e enquanto sujeito e objeto do conhecimento social. Essa necessidade funda-se no caráter dialético da realidade social que é, ao mesmo tempo, uma e diversa e na natureza intersubjetiva da sua apreensão. Já como problema, a interdisciplinaridade se apresenta pelos limites do sujeito que busca construir o conhecimento de uma determinada realidade e, de outro lado, pela complexidade desta realidade e seu caráter histórico. Mesmo que um sujeito individual atinja um elevado nível de capacidade crítica, ele não dará conta de exaurir determinada problemática. Por esse ângulo, percebemos que o conhecimento humano sempre é relativo, parcial e incompleto. Daí a relevância de se buscar esclarecer, revelar, expor não toda a realidade de um fato, mas sim as suas determinações e mediações fundamentais.

Dessa forma, para Frigotto o trabalho interdisciplinar:

... se apresenta como uma necessidade imperativa pela simples razão de que a parte que isolamos ou arrancamos "do contexto originário do real" para poder ser explicada efetivamente, isto é, revelar no plano do pensamento e do conhecimento as determinações que assim a constituem, enquanto parte, tem que ser explicitada na integridade das características e qualidades da totalidade. É justamente no exercício de responder a essa necessidade que o trabalho interdisciplinar se apresenta como um problema crucial, tanto na produção do conhecimento quanto nos processos educativos e de ensino (FRIGOTTO, 1995, p.33).

Muitas vezes, os trabalhos interdisciplinares, resumem-se à junção de diversas partes isoladas que pouco contribuem para o entendimento da dinâmica socioambiental. A idéia de interdisciplinaridade ainda se confunde bastante como uma "colagem" de conteúdos, onde disciplinas próximas proporcionam a realização de atividades conjuntas no desenvolvimento de temas comuns.

Para Tristão (1992), não se pode confundir interdisciplinaridade com a simples integração entre disciplinas. Enquanto a integração se limita a aspectos superficiais de 
complementaridade, a interdisciplinaridade requer mudanças profundas em todo o processo educacional, substituindo a concepção fragmentária do conhecimento pela visão holística do ser humano no mundo, refletindo o comprometimento do indivíduo com o futuro dessa realidade. Ainda segundo a autora, a interdisciplinaridade desencadeia um processo emancipatório, pressupõe que todo o conhecimento é de igual relevância, o que implica romper com as barreiras colocadas entre as ciências naturais e humanas e implica a superação da dicotomia existente entre o ensino e pesquisa e entre teoria e prática, como instrumento para compreender a realidade social.

Segundo Frigotto (1995) o modo de pensar fragmentário, linear, produz conhecimentos que, transformados em ação, trazem inúmeros problemas concretos ao conjunto da humanidade. As relações predatórias de produção e a exclusão social crescente trazem problemas tanto no plano social com a miséria, a violência, as epidemias, como no plano da natureza, com o desmatamento, a poluição e outros.

No plano da organização do processo pedagógico, o resultado da concepção fragmentária e positivista da realidade vai se expressar de um lado na interminável lista de disciplinas e de outro na divisão arbitrária entre disciplinas de conteúdo geral, humano, e disciplinas de conteúdos específicos e técnicos. A superação desses desafios certamente implica a capacidade de atuar dentro da dialética do velho e do novo, ou seja, da crítica à forma fragmentária da produção da vida humana em todas as suas dimensões e, especificamente, na socialização do comportamento e na construção de novas relações sociais que rompam com a exclusão e a alienação (Frigotto, 1995).

Sobre essa dificuldade de articulação entre os diferentes saberes, característico de uma educação linear e de estrutura curricular rígida, a Carta de Belgrado alertou que no caso da educação escolar, a Educação Ambiental não deve se constituir como uma sobreposição de matérias, mas refletir uma abordagem interdisciplinar baseada em projetos de ação conjunta (SÃO PAULO, 1994).

Apesar de todas as discussões e proposições que já ocorreram e que ocorrem sobre práticas interdisciplinares desde a Conferência de Estocolmo em 1972, segundo GonzálesGaudiano, a interdisciplinaridade:

... continua sendo um horizonte de possibilidades dentro da educação, que não conseguiu uma adequada definição no currículo escolar de todos os níveis, além disso a pesquisa sobre o tema foi descontínua. A educação escolar, em seus variados níveis e modalidades, permanece submetida aos ditados e às severas limitações das disciplinas convencionais”(GONZÁLEZ-GAUDIANO, 2005, p. 120). 
Não foi a questão ambiental que inventou a interdisciplinaridade, mas provavelmente foi a principal responsável pela sua revalorização na matriz epistemológica (Segura, 2001). Nesse sentido, a Educação Ambiental vem resgatar a importância de se trabalhar com as diversas áreas do conhecimento numa sociedade que radicalizou a divisão dos saberes em especialidades. Agregar as diferentes visões de mundo responde à necessidade de entender a complexidade das relações que compõem a experiência humana e não-humana.

Para González-Gaudiano (2005), o momento em que surge a Educação Ambiental está marcado por diversas disputas nos campos político, econômico, social e cultural e por isso, há necessidade de definir sua identidade frente a outros campos da educação, sendo a interdisciplinaridade um recurso adequado, mas não aberto a um debate apropriado que se reconheça como uma área de convergência disciplinar entre as ciências naturais e sociais porque tais áreas estão em conflito epistemológico e socioprofissional.

Queira-se ou não, o tema da interdisciplinaridade ainda permanecerá articulado por um longo tempo aos temas de meio ambiente e sustentabilidade, uma vez que este continua sendo a melhor proposta de trabalho integrado para esses campos que não se identificam com nenhuma disciplina em particular, mas com suas múltiplas interações. Contudo, GonzálezGaudiano (2005) salienta que apenas o ensino superior, com a organização em sistemas modulares aproxima-se de expressões que buscam romper com a organização curricular centrada nas disciplinas convencionais. Ainda de acordo com o autor, embora a proposta dos eixos transversais na educação fundamental tenham encontrado uma boa realização, mudanças significativas ainda são muito pontuais. Para Tristão (1992, p.57) "a interdisciplinaridade só se concretizará pela modificação radical dos hábitos pedagógicos”. Nesse sentido, partiremos agora para uma reflexão e análise dos projetos e das propostas de trabalho com os temas transversais, buscando identificar os motivos desse descompasso entre a teoria e a prática.

\section{ENSINAR E APRENDER NOS PCNs}

Por muito tempo a Pedagogia focou o processo de ensino no professor, supondo assim que estaria valorizando o conhecimento. Com isso, o ensino ganhou autonomia em relação à aprendizagem criando seus próprios métodos enquanto o processo de aprendizagem ficou relegado a um segundo plano. Hoje, sabe-se que é necessário fazer uma ressignificação entre a unidade de ensino e aprendizagem, uma vez que, sem aprendizagem, o ensino não se realiza (BRASIL, 1997a). 
Um dos marcos explicativos que permite essa ressignificação pode ser encontrado na perspectiva construtivista ${ }^{25}$ que é configurada por uma série de princípios explicativos de desenvolvimento e da aprendizagem humana que se complementam. Através desta perspectiva, o conhecimento não é visto como algo situado fora do indivíduo, a ser adquirido por meio de cópia do real ou construído independentemente da realidade exterior; é antes de mais nada, uma construção histórica e social, na qual interferem fatores de ordem cultural e psicológica e onde a atividade construtiva, física ou mental, permite interpretar a realidade e construir significados, ao mesmo tempo que permite construir novas possibilidades de ação e de conhecimento (BRASIL, 1997a).

Hoje, a pedagogia valoriza o pensamento construído pelo aluno em vários espaços que o auxiliam no desenvolvimento de novas aprendizagens. Segundo os PCNs:

O que o aluno pode aprender em determinado momento da escolaridade depende das possibilidades delineadas pelas formas de pensamento de que dispõe naquela fase de desenvolvimento, dos conhecimentos que já construiu anteriormente e do ensino que recebe. Isto é, a intervenção pedagógica deve-se ajustar ao que os alunos conseguem realizar em cada momento de sua aprendizagem, para se constituir verdadeira ajuda educativa. O conhecimento é resultado de um complexo e intrincado processo de modificação, reorganização e construção, utilizado pelos alunos para assimilar e interpretar os conteúdos escolares (BRASIL, 1997a, p.51).

Com isso, podemos observar que nada pode substituir a atuação do próprio aluno na tarefa de construir significados sobre os conteúdos da aprendizagem, por mais que o professor, os companheiros de classe e os materiais didáticos possam e devam, contribuir para que essa aprendizagem se realize. As aprendizagens serão significativas, à medida que os alunos estabelecerem relações substantivas e não-arbitrárias entre os conteúdos escolares e os conhecimentos previamente construídos por eles, num processo de articulação de novos significados. Assim, aprendizagens significativas implicam sempre em alguma forma de ousadia, onde o aluno diante de um problema posto, precisa elaborar hipóteses e experimentálas.

Com base no que já expusemos até o presente momento e na nossa concepção sobre a importância da qualidade das práticas desenvolvidas na Educação Ambiental, principalmente

\footnotetext{
${ }^{25}$ Derivado principalmente das teorias da epistemologia genética de Jean Piaget e da pesquisa sócio-histórica de Vigotski, o construtivismo é uma das correntes teóricas empenhadas em explicar como a inteligência humana se desenvolve, partindo do princípio de que o desenvolvimento da inteligência é determinado pelas ações mútuas entre o indivíduo e o meio.
} 
com relação às atividades de aprendizagem, iniciaremos uma reflexão no Materialismo Histórico-Dialético, que nos dará um aporte para percorrermos os caminhos da abordagem Histórico-Cultural, passando pela Teoria da Atividade e chegando finalmente nas Atividades Orientadoras de Ensino para estabelecermos as relações e discussões com as práticas e atividades desenvolvidas pelas professoras de $3^{a}$ e $4^{a}$ séries do Ensino Fundamental da Diretoria de Ensino Centro Sul.

\section{TEMAS TRANSVERSAIS: UMA PROPOSTA PARA A EDUCAÇÃO AMBIENTAL}

Uma avaliação realizada por especialistas em educação sobre as disciplinas básicas do currículo, indicou que elas apesar de serem necessárias para acessar o conhecimento acumulado, não estão dando conta de alguns temas presentes no cotidiano como: violência, saúde, ambiente, preconceito e outros. A partir disso, o Ministério da Educação e Cultura (MEC), propôs uma reorientação curricular e uma discussão sobre qual é a escola que se deseja nos dias de hoje e quais os conteúdos que ela deve trabalhar através dos Parâmetros Curriculares Nacionais (PCNs) com cinco temas transversais: ética, saúde, meio ambiente, orientação sexual e pluralidade cultural (BRASIL, 1997a).

Os PCNs incorporam os temas transversais nas disciplinas convencionais, relacionado-os à realidade e dessa forma, tornando os conteúdos instrumentos de reflexão para uma ação na realidade, na qual o educador é visto como um facilitador na introdução de práticas comprometidas com os interesses da comunidade onde se está inserido (BRASIL, 1997a).

Para Segura (2001) a possibilidade de se trabalhar os conteúdos, através de uma abordagem transversal, pode significar um salto de qualidade no processo de formação dos alunos, que passariam a entender o que estudam e dos professores, uma vez que seriam estimulados a enfrentar o conhecimento de forma mais criativa e dinâmica. Apesar disso, percebe-se ainda a necessidade de se discutir com todos os agentes envolvidos no processo educativo, o sentido e formas de traduzir essa proposta em ações educativas, principalmente quanto à cultura arraigada dos professores de trabalharem com o conhecimento de forma fragmentada, disciplinada, como a própria organização do tempo de trabalho das escolas, sob o risco de se ver mais um projeto como tantos outros serem jogadas numa vala comum pela falta de discussão e decodificação por todos aqueles que atuam nas escolas (SEGURA, 2001).

Com relação à proposta de meio ambiente nos PCNs, a principal função do trabalho com o tema é: 
contribuir para a formação de cidadãos conscientes, aptos para decidirem em sociedade e atuarem na realidade socioambiental de modo comprometido com a vida, com o bem estar de cada um e da sociedade, local e global. Para isso é necessário que, mais do que informações e conceitos, a escola se proponha a trabalhar com atitudes, com formação de valores, com o ensino e a aprendizagem de habilidades e procedimentos (BRASIL, 1997).

A opção pelo trabalho com o tema meio ambiente traz para a escola e principalmente para os professores, a necessidade de adquirirem informações e conhecimentos para que se possa desenvolver um trabalho adequado junto dos alunos, o que não significa dizer que os professores deverão saber tudo, mas sim serem capazes de mostrar que a produção do conhecimento é constante e que ela se dá por um processo de interação e reflexão. Com isso, espera-se que os alunos sejam capazes de construir uma consciência global das questões relativas ao meio e possam atribuir significado àquilo que aprendem em Educação Ambiental, podendo assim, compreender e atuar sobre sua própria realidade. (BRASIL, 1997).

Apesar das várias orientações e sugestões encontradas nos documentos referentes à implantação dos PCNs (Brasil 1997, 1997a), observamos ainda uma série de problemas e dificuldades na viabilização desta proposta de trabalho. Uma das críticas iniciais, refere-se ao seu processo de elaboração que, baseado numa metodologia de centralização, não teve a participação de órgãos e entidades representativas da área educacional, sem discussões amplas com a sociedade. Além disso, de acordo com Castro, Spazziani e Santos (2002), nesses anos iniciais de sua utilização, tem-se observado, principalmente nas séries iniciais do primeiro ciclo do Ensino Fundamental, apenas uma adequação dos planos e programas curriculares dos professores aos conteúdos propostos pelos documentos oficiais, sem que isso reflita mudanças na prática da sala de aula. Assim, observam-se intenções explícitas nos programas, mas as práticas pedagógicas não sofreram mudanças significativas.

Além desse descompasso entre o que os PCNs propõem e como eles realmente são traduzidos na prática, eles pouco ajudaram na diferenciação e compreensão entre trabalho com projetos, interdisciplinaridade e temas transversais. Por isso, torna-se importante abrir uma discussão ampla e profunda com todos os educadores, a fim de se definir posições mais claras e objetivas sobre os modos de inclusão dessas questões no currículo escolar bem como um maior investimento na capacitação e formação continuada dos professores no sentido de superação da falta de clareza quanto à relação entre os conteúdos e transversalidade. 


\section{PRÁTICAS EDUCATIVAS DE EDUCAÇÃO AMBIENTAL COMO ATIVIDADE HUMANA.}

Para refletirmos sobre práticas educativas, tomaremos por base os trabalhos elaborados e desenvolvidos principalmente por Oliveira, Almeida e Arnoni (2007), uma vez que eles muito se aproximam das nossas idéias sobre práticas escolares de Educação Ambiental. Para os autores, prática educativa é o trabalho pedagógico desenvolvido pelo professor, que envolve o processo de ensino, cuja intencionalidade é influenciar o processo de aprendizagem desenvolvido pelo aluno: a relação entre o processo de ensino e o de aprendizagem. Assim nessa concepção, a prática educativa constitui um processo consciente, deliberado e sistemático, pelo qual se trabalha o saber cultural produzido historicamente por intermédio da relação pedagógica. Ainda segundo os autores, a intencionalidade da prática educativa consiste em ensinar os bens culturais produzidos pelo gênero humano, para que o aluno, sujeito da aprendizagem, tenha uma concepção de ambiente menos imediata, e portanto mais articulada, podendo assim, agir criticamente, e não de forma alienada.

Aqui a palavra prática preserva o significado de práxis enquanto um conceito filosófico da atividade teórico-prática do ser humano em sociedade. A práxis é uma categoria filosófica que permite a compreensão da dinâmica do ambiente e possibilita a ação crítica do ser social, no sentido da transformação. Também é utilizada para explicitar a dimensão filosófica do trabalho teórico-prático que o professor desenvolve em uma aula.

Pensar na prática educativa, ou seja, pensar na práxis implica segundo os autores em abandonar a improvisação - uma ação que corrói a autonomia de qualquer profissional e, em especial, a do professor - colaborando para a alienação. A improvisação, na docência, torna o professor um mero executor de atividades pensadas e programadas por outros.

Outra questão importante que se relaciona com a práxis, refere-se à intencionalidade do ato educativo que exige do professor a compreensão teórica de suas práticas em relação ao processo de ensino que potencializa no aluno a aprendizagem do conteúdo. A respeito disso, Oliveira, Almeida e Arnoni (2007) ressaltam que mesmo o professor não tendo essa concepção teórica sobre a intencionalidade da aula, sua ação não é sem teoria, pois ela está relacionada, de forma inconsciente, às concepções de educação que ele elaborou em sua caminhada. Porém essa teoria não lhe permite desenvolver uma atitude propriamente teórica diante da aula (prática educativa), ou seja, não lhe permite dialetizar teoria e prática. Com isso, há uma redução do conceito de prática educativa em prática utilitária, ou melhor, da 
prática pragmática que fala por si mesma, sem o caráter problemático da contradição que se estabelece entre as dimensões teórica e prática da práxis.

Diante desse afastamento da atividade teórica, das necessidades imediatas das práticas educativas, esta acaba se apresentando ao professor como uma atividade dispensável. A respeito disso, os autores comentam que o professor estuda teorias, sabe verbalizá-las e, muitas vezes, a partir delas, interpreta a realidade da sala de aula, porém não consegue transformar seu cotidiano escolar, permanecendo o hiato entre teoria e prática e, até mesmo, reforçando o caráter pragmático da aula. Essa concepção de prática sem teoria gera a alienação do professor. Para eles:

\begin{abstract}
A alienação é um processo ligado essencialmente à ação e à consciência dessa ação, em relação à situação dos homens organizados em sociedade. Pela alienação, se oculta ou se falsifica essa ligação (ação e consciência dessa ação), de modo que apareça o processo da ação e seus produtos como independentes. Assim, para o observador ingênuo, o mundo parece constituído de coisas independentes umas das outras e indiferentes à consciência (OLIVEIRA, ALMEIDA e ARNONI, 2007, p.
\end{abstract} 129).

Discutido um pouco sobre as questões das práticas educativas, partiremos agora para uma reflexão sobre o conceito de atividade. Para Sanches Vazquez (1977, p 186) atividade é "o ato ou o conjunto de atos em virtude do qual um sujeito ativo modifica determinada matéria prima" ou uma matéria exterior, inerente ao sujeito.

Para se conceber uma "atividade" como propriamente humana, faz-se necessário recorrer ao que lhe é específico, ou seja, a sua intencionalidade. Dessa forma só é possível identificar uma "atividade humana" quando os atos dirigidos para a transformação de um objeto se iniciam com uma finalidade ou resultado ideal e terminam com um produto efetivo ou resultado real.

A "atividade humana" ocorre pelas necessidades desencadeadas pela insatisfação do homem com seu presente, pois se ele vivesse em plena harmonia com a sua realidade, ou vivesse conciliado com seu presente, não sentiria a necessidade de negá-los idealmente nem de configurar em sua consciência uma realidade ainda para ele inexistente. Caracterizada desse modo, a "atividade humana" se realiza predominantemente e de forma geral pelo processo de trabalho. Para Marx, o processo do trabalho é a: 
atividade orientada a um fim para produzir valores de uso, apropriação do natural para satisfazer as necessidades humanas, condição universal do metabolismo do homem e a natureza, condição natural eterna da vida humana e, portanto, independente de qualquer forma dessa vida, sendo antes igualmente comum a todas as suas formas sociais (MARX, 1985, p. 153).

Assim, ao mesmo tempo em que o homem realiza ações transformando os elementos e objetos da natureza física em produtos do seu trabalho, ele transforma sua própria natureza inicial, cria inúmeras capacidades em si próprio, alterando substancialmente sua condição de ser vivo.

Para Marx (1985), com o advento da propriedade privada e, particularmente, da formação social capitalista, o "trabalho em geral", elemento constituído e constitutivo do ser humano, transforma-se em elemento destruidor desse mesmo sujeito que o produziu. Assim, diante dessas terríveis conseqüências do capitalismo, Marx (1983) ressalta a necessidade de uma ação transformadora revolucionária do próprio homem, considerando que o mesmo elemento que impede seu desenvolvimento pode gerar também a sua superação. Superação que pode ser conseguida não através de uma ação revolucionária, mas através da apropriação da experiência social elaborada.

\section{ABORDAGENS PSICOLÓGICAS DA ATIVIDADE HUMANA}

Os primeiros anos após a revolução socialista de 1917, ainda na extinta URSS, foram extremamente férteis para diversos segmentos da produção científica e cultural, quando alimentados por uma perspectiva de transformação social, inúmeros cientistas puseram-se a pesquisar sobre a melhor possibilidade de inclusão social das classes historicamente desfavorecidas ou excluídas. Rapidamente, as produções intelectuais espalharam-se pela Europa e transformaram-se em paradigmas para inúmeras produções científicas.

Ao buscarem referência no materialismo histórico ${ }^{26}$, autores como Vigotski (18961934), Leontiev (1903-1979) e Luria (1902-1977) influenciaram e continuam a ser referência para as pesquisas relacionadas com os processos de ensino-aprendizagem.

\footnotetext{
${ }^{26}$ Pensamento da Teoria Marxista que abriu um campo para o estudo dos processos históricos e econômicos e para a análise das estruturas e dos processos que integram o todo social, com uma visão mais abrangente de suas diferentes instâncias e processos. LEFF, Enrique. Epistemologia ambiental. Tradução de Sandra Vanezuela. $2^{a}$ edição. São Paulo: Cortez, 2002.
} 
Oliveira (1997) ao fazer uma síntese de alguns pressupostos de Vigotski, observa que ele inaugura a perspectiva histórico-cultural ao propor quatro planos genéticos que interagem na formação do psiquismo de crianças e adolescentes:

1) Filogênese: relacionada com as habilidades e formas de desenvolvimento cognitivo que estão presentes em todos os indivíduos, independente do contexto no qual estão inseridos;

2) Ontogênese: é a formação individual, tanto dos aspectos motores quanto psíquicos;

3) Sociogênese: explicita que a formação motora e psíquica do indivíduo está impregnada de significados histórico-culturais;

4) Microgênese: plano genético que interage com os outros, caracterizando o psiquismo individual no entrecruzamento do biológico, do histórico e do cultural.

Assim, a perspectiva histórico-cultural se diferencia de outras, em que o processo da ontogênese encontra-se na sociogênese, uma vez que práticas tidas como universais como andar, comer, beber, falar, (ontogênese) ganham significados e formas de aprendizado diferentes em função do contexto no qual a criança está inserida (sociogênese).

Nessa perspectiva, Soares conclui que:

...vê-se o desenvolvimento do psiquismo na criança como fruto de um intrincado processo de interações entre ele e o mundo dos adultos. Sabemos que a criança traz consigo o potencial e os princípios fundamentais para o seu desenvolvimento biológico, porém é o mundo dos adultos que transmite formas de socialização e características culturais e estas interferem no seu desenvolvimento (SOARES, 2005, p. 31-32).

Leontiev observa que o homem moderno tem no desenvolvimento do seu psiquismo estruturas cognitivas diferentes dos homens que viviam em grupos não constituídos como sociedades de classes e que a alienação implícita ao modo de produção capitalista identificada na separação entre o trabalho manual e intelectual, interfere nos processos psíquicos de formação de consciência. Assim para o autor, "a primeira transformação da consciência, engendrada pelo desenvolvimento da divisão social do trabalho constitui, portanto, no isolamento da atividade intelectual teórica” (LEONTIEV, 1978, p. 120). 
Norteando-se pelos princípios do materialismo histórico-dialético, Vigotski vai buscar na apreensão do movimento histórico da humanidade a origem do comportamento contemporâneo do ser humano.

O modo de produção capitalista retirou do homem o seu saber-fazer e isto se incorporou aos seus processos psíquicos, fazendo com que suas ações e o trabalho fiquem desprovidos de sentido ou tenham apenas um sentido imediato, de supressão de suas necessidades básicas. A partir disso, podemos compreender o conceito de atividade em Leontiev uma vez que, se a consciência do homem que vive no mundo capitalista está impregnada da divisão social e se esta submete o sujeito à separação entre o saber e o fazer, cabe aos que têm consciência desta inadequação, a tarefa de proporcionar aos homens a integração destes dois campos da consciência humana.

Com isso, podemos observar que, se a formação da consciência for entendida como processo cognitivo que se vincula ao contexto sócio-histórico, do ponto de vista pedagógico, a formação dessa consciência depende da atuação de adultos (e aqui em especial do professor) que convive com crianças e adolescentes, em que o maior objetivo de uma atividade de ensino, em linhas gerais, seria o de possibilitar o intercâmbio entre o saber e o fazer, superando assim a forma de alienação presente no modo de produção capitalista. Dessa forma, a corrente histórico-cultural valoriza a escola e os espaços de ensino aprendizagem como lócus fundamental para processos de tomada de consciência individual e coletiva.

Segundo Oboukhova (2006), na teoria de Vigotski, a consciência humana não é concebida como a soma de processos psicológicos separados, mas como um sistema, uma estrutura de processos, nas quais nenhuma função se desenvolve de forma isolada. Desse modo, em períodos iniciais do desenvolvimento, a "percepção" é o núcleo da consciência, na idade pré-escolar é a "memória" e na etapa escolar, o "pensamento". Para a autora, o desenvolvimento psíquico consiste na reestruturação da consciência que acontecerá por sua vez com o desenvolvimento da consciência.

A partir disso, podemos nos questionar: mas como produzir essas mudanças na estrutura da consciência? Para Oboukhova (2006), o único meio possível para se ter acesso à consciência é através da fala, e a transição de uma estrutura da consciência para outra é acompanhada do desenvolvimento das generalizações.

$\mathrm{Na}$ escola e nos espaços de ensino aprendizagem merecem destaque o papel da mediação, entendida como um processo pedagógico fundado no agir comunicacional docente que pode levar a mudanças qualitativas na aprendizagem. Nesse sentido, Soares afirma que: 
... o adulto-professor não pode se limitar a observar e dar suporte para as crianças ao longo das atividades, mas precisa ter uma participação ativa no processo pedagógico: interagir com o grupo e mobilizá-lo, com o intuito de promover a interação e a integração, desafiando-os para a resolução de diferentes atividades, individuais e coletivas (SOARES, 2005, p. 34).

Oliveira, Almeida e Arnoni (2007) alertam para a imprecisão dos sentidos que a palavra mediação pode assumir entre os investigadores da educação. Para os autores, ela pode se referir ao termo médio de uma relação entre elementos eqüidistantes ou à ligação entre dois termos distintos, ou ainda à passagem de um termo para outro como também pode dizer respeito à harmonização de conflitos entre interesses opostos (antagônicos ou não). Assim pode-se falar, por exemplo, no papel do professor como mediador da relação entre o ensino e a aprendizagem, ou do caráter mediador presente na ligação que se estabelece entre o conhecimento sistematizado pelas ciências e aquele que o aluno desenvolve no seu cotidiano. Dessa forma, atribui-se à mediação o dever ou a responsabilidade de eliminar ou minimizar a diferença entre os termos ensino e aprendizagem.

Entendida dessa forma, a mediação tem o sentido de união, de unificação, de igualdade e, sobretudo, é compreendida como resultado, como produto de uma relação entre dois elementos opostos (antagônicos ou não) que, por meio dela, podem ser homogeneizados. Para os autores, tal concepção, apesar de aparentemente contribuir para o entendimento do processo educativo, está distante daquela desenvolvida na filosofia.

A mediação é uma categoria filosófica e dialética e por isso não pode ser considerada um produto - uma vez que esta noção não tem lugar na dialética. Ela aceita apenas a idéia de processo que se pauta nas noções de movimento e negação que só adquirem sentido na perspectiva da superação.

De acordo com Oliveira, Almeida e Arnoni (2007), a mediação permite que, pela negação, o imediato (o aqui e agora, o estritamente natural) seja superado no mediato (é o que passa pelo pensamento e pela elaboração humana) sem que o primeiro seja anulado ou suprimido pelo segundo, ao contrário, o imediato está presente no mediato e este está presente naquele, então ela é a responsável pela reflexão recíproca de um termo no outro.

\section{A TEORIA DA ATIVIDADE}

Logo no início da década de 30, Alexei Nicolaievich Leontiev e Alexandr R. Luria, ambos discípulos e seguidores de Vigotski, constituem as bases da "Teoria da Atividade" 
juntamente com outros colaboradores, dando prosseguimento aos estudos da "atividade humana", sobre sua estrutura psicológica e a utilização de instrumentos pelo homem (GOLDER, 2002).

A organização conceitual das análises realizadas pelos autores soviéticos está alicerçada numa concepção do desenvolvimento da criança, na qual o "social" e a "atividade" são os conceitos centrais. O social, por um lado, pode se constituir como a fonte do desenvolvimento conceitual da criança e por outro, como a organização da atividade comum e do aprendizado do aluno (GARNIER; BEDNARZ; ULANOVSKAYA, 2003).

Nas suas pesquisas iniciais, Leontiev investigou a formação dos processos psicológicos superiores ${ }^{27}$, em especial a memória e a atenção, para posteriormente dedicar-se a compreender os elementos constitutivos da configuração da "atividade". Como em seus estudos psicológicos a ênfase estava na "atividade humana", a "atividade" era a unidade de análise de sua formulação teórica, ou seja, era a categoria central.

Ao analisar a estrutura da atividade, Leontiev (1983) demonstrou que essa surge após a manifestação de uma necessidade. Assim podemos concluir que isso confere à necessidade o caráter de ser a condição primeira de uma atividade, mas Leontiev (1978, p. 108) adverte: "todavia, em si, a necessidade não pode determinar a orientação concreta de uma actividade, pois é apenas no objeto da atividade que ela encontra a sua determinação: deve, por assim dizer, encontrar-se nele".

Com relação à necessidade, esta só se realiza através de um objeto que lhe é adequado. Assim, por exemplo: "a sede é uma necessidade que somente se encerra na medida em que o objeto adequado à sua satisfação, a água, esteja disponível para que a atividade de beber possa-se dar" (GARNIER; BEDNARZ; ULANOVSKAYA, 2003, p. 13).

Para Leontiev (1969), as necessidades possuem várias características diferentes, tais como:

- toda necessidade tem um objetivo, um fim;

- a necessidade adquire um conteúdo concreto segundo as condições e a maneira como se a satisfaz;

- a capacidade de se repetir em situações diversas e em diferentes momentos da vida dos indivíduos;

\footnotetext{
${ }^{27}$ Para Vigotski (1987) as funções psicológicas superiores são a linguagem, o pensamento, a memória, a atenção voluntária, a afetividade. Caracterizam-se por serem operações psicológicas indiretas, que necessitam de um signo mediador, a linguagem por excelência. São funções que necessitam de uma natureza histórica e são de origem sociocultural, são mediadas.
} 
- toda a necessidade se desenvolve na medida em que se amplia o círculo de objetos e de meios para satisfazê-la.

O surgimento de necessidades gera motivos que mobilizam os seres humanos a agir orientados por determinados objetivos, no qual o motivo está relacionado ao objetivo da atividade; àquilo que se intenciona alcançar. $\mathrm{O}$ motivo não é algo que se refere a sentimentos em geral, ele parte das necessidades do sujeito, impulsionando-o a agir, pois sem ele não ocorre o movimento da "atividade" (LEONTIEV, 1978).

Ainda de acordo com Leontiev (1983) as funções que os motivos podem exercer em uma atividade são relativas, uma vez podem variar de atividade para atividade: ele pode ser um motivo geral que dota uma atividade de sentido ou ainda ser um motivo complementar como um motivo-estímulo e nesse caso ser considerado como a força impulsionadora da atividade.

Para isso, Leontiev (1988) elaborou um exemplo hipotético entre duas crianças diante de seus deveres escolares em início de escolaridade. Uma delas faz seus deveres porque quer receber boas notas na escola e a outra, porque quer brincar, uma vez que só foi permitido que ela brincasse após concluir seus deveres. No primeiro caso, Leontiev denomina os motivos como "motivos compreensíveis" e no segundo como "motivos eficazes". Eficaz, porque brincar coincide com o objetivo da "atividade principal": o jogo, o brinquedo.

Uma vez instituída essa situação, o motivo pode se alterar e assim, conseqüentemente, alterar a atividade. Essa segunda criança pode passar a realizar seus deveres escolares de maneira própria não mais porque ela quer brincar, mas porque passou a receber boas notas e o reconhecimento das pessoas com as quais interage socialmente. Assim ela passa a atuar segundo "motivos compreensíveis", que mais tarde, poderão novamente tornar-se "motivos eficazes", porque mobilizarão a criança a desempenhar ações que pertençam a uma outra atividade principal: o estudo. Com isso Leontiev conclui que "só motivos compreensíveis tornam-se motivos eficazes em certas condições e é assim que novos motivos surgem e, por conseguinte, novos tipos de atividade" (LEONTIEV, 1988, p.70).

Outro elemento constituinte da estrutura da "atividade" é a ação. As ações são sempre desempenhadas pelos sujeitos, decorrem de motivos e esses podem ser externos ou internos ao sujeito da "atividade", ou ainda podem ser individuais ou coletivos. Para Leontiev (1978), a ação é um processo cujo motivo não coincide com aquilo que ele visa, ou seja, com seu objeto, pois ela pertence à atividade em que entra a ação considerada. Por exemplo, se um grupo de pessoas se coloca na captura de um animal para dele se alimentar (objeto, atividade 
principal) e em determinado momento começam a balançar os braços (ação), com o objetivo de cercar e encurralar o animal, observamos que o motivo da ação (balançar os braços) não coincide com o objeto principal que é a captura do animal para dele se alimentar, mas está relacionado com a atividade de cercar o animal.

Para Duarte (2003), quando a atividade passa a ser composta de unidades menores, as ações, isso quer dizer que cada uma das ações individuais componentes da atividade coletiva deixa de ter uma relação direta com o motivo da atividade e passa a manter uma relação indireta, mediatizada com aquele motivo. O significado de uma ação diz respeito ao conteúdo da ação e o sentido da mesma diz respeito às razões, aos motivos pelos quais o indivíduo age.

De acordo com Leontiev, na sociedade capitalista opera-se uma ruptura alienada e alienante entre o significado da ação do operário e o sentido que essa ação tem para ele, ou seja, uma ruptura entre o conteúdo da ação do operário e o motivo pelo qual o operário age. Dessa forma, segundo Duarte:

Se ele trabalha, por exemplo, na indústria de tecelagem, seu trabalho tem o significado de produzir o tecido do qual necessita a sociedade, mas, em razão da venda da força de trabalho para o capital, o sentido que tem para o trabalhador a sua própria atividade é dado pelo salário que recebe, isto é, pelo valor de troca de sua força de trabalho. Daí ser possível que esse sentido adquira total independência em relação ao conteúdo da atividade de trabalho (DUARTE, 2003, p. 8-9).

Ainda com relação às ações, segundo Leontiev, seu processo de formação ganha complexidade quando se trata da formação das ações interiores:

tal como a influência dos objetos humanos, a influência dos conceitos, dos conhecimentos em si não é susceptível de provocar na criança reacções adequadas; com efeito, a criança deve antes se apropriar deles. Para o fazer,o adulto tem de construir activamente estas acções na criança; mas contrariamente às acções exteriores, as acções interiores não podem ser criadas directamente do exterior (LEONTIEV, 1978, p. 187).

Para concluirmos a caracterização da "atividade", ainda precisamos falar de mais um elemento que faz parte da sua estrutura: a operação, ou seja, o meio ou o modo de realização de uma ação ou ações no interior de uma atividade. Assim, quando uma ação externa é internalizada e se converte em ação mental, para a realização de uma nova ação, constitui-se como uma operação (LEONTIEV, 1978). 
Caracterizada a "atividade" com todos seus elementos constituintes: necessidade, motivo, ação e operação, utilizaremos um exemplo que busca mostrar como todos os elementos de uma "atividade" se articulam e fazem intercâmbios uns com os outros:

Assim que as crianças aprendem a ler, a leitura pode ser considerada uma ATIVIDADE composta de diferentes ações; no entanto, tão logo este aprendizado chega a seu final, a leitura pode tornar-se uma AÇÃO ou mesmo uma OPERAÇÃO no interior do sistema formado por uma atividade. É o caso, por exemplo, da leitura de uma situação que propõe a resolução de problemas matemáticos. Em um caso assim, as crianças devem ler o texto, o que aparece então, como apenas uma das OPERAÇÕES a serem realizadas para poder resolver os problemas. Por outro lado e em outra situação, como por exemplo a que consiste em preparar-se para um exame, a leitura de um livro visando à sua análise constituir-se-á em uma AÇÃO, já que o verdadeiro MOTIVO vincula-se à obtenção de um bom resultado no exame e não ao conteúdo do livro propriamente dito (GARNIER; BEDNARZ; ULANOVSKAYA, 2003, p. 14, grifos do autor).

Com base no desenvolvimento do conceito central de "atividade", Leontiev (1975) ressaltou a especificidade da atividade da criança em cada idade, na qual a mudança de atividade estaria na base da periodicidade do desenvolvimento da criança, o que determinaria as suas mudanças psicológicas, assim como a sua consciência e suas relações com seu ambiente. Dessa forma, a atividade lúdica ocorreria na faixa etária de 3 a 6 anos e depois a atividade de aprendizado entre os 6 e os 11 anos.

É com base nestas idéias, como a da importância que é dada para a educação e para o desenvolvimento de ações capazes de levar os alunos a se apropriarem da experiência humana para se tornarem sujeitos capazes de realizar ações intencionais mediante o desenvolvimento dos processos psíquicos superiores, especialmente da capacidade de refletir e agir no mundo ao seu redor, que acreditamos na importância da qualidade das práticas de Educação Ambiental desenvolvidas no Ensino Fundamental.

\section{ATIVIDADE DE ESTUDO, ATIVIDADE DE APRENDIZAGEM E ATIVIDADE ORIENTADORA DE ENSINO.}

A partir do ingresso da criança na vida escolar, surgem novas exigências sociais, novas habilidades e novas atitudes passam a formar a pessoa. O âmbito e a qualidade das relações sociais são redimensionadas com alterações na qualidade do processo de 
aprendizagem. A aprendizagem ocorrida por meio de brincadeiras, do convívio com os adultos e até mesmo do trabalho precoce é distinta da que pode ocorrer na escola, uma vez que esta oferece a possibilidade sistematizada de apropriação de elementos da produção cultural de uma dada formação social em determinado período de tempo, vinculada à consciência e pensamento teóricos.

Ao investigar as neoformações psíquicas de estudantes, pesquisadores russos e alemães durante a década de 70, pautando-se nos referenciais teórico-metodológicos da Psicologia Soviética, especialmente os formulados por Vigotski, Elkonin e Leontiev, concluíram que nem todo o ensino ou educação escolar promove o desenvolvimento psicológico da criança ou tem como motivo a aprendizagem, pois para que isso ocorra, faz-se necessário organizar a "atividade" dos estudantes com o objetivo de promover situações que contribuam para a superação, pelo menos, do pensamento empírico ${ }^{28}$.

Sendo assim, é isso o que esperamos das práticas de Educação Ambiental desenvolvidas no ensino fundamental: que se constituam como atividades capazes de promover a transformação do sujeito, de formação e desenvolvimento dos processos psíquicos superiores ou ainda segundo Leontiev (1967) como um processo de apropriação de elementos culturais produzidos pela experiência humana historicamente constituída, Resumindo, que se constituam como "atividades de aprendizagem".

A Psicologia Moderna e a Didática distinguem dois tipos de conhecimento: o saber empírico e o saber teórico. Com base nas conclusões de Davidov (apud RUBTSOV, 2003, p. 129) “o conhecimento empírico é elaborado quando se compara os objetos às suas representações... Já o saber teórico repousa numa análise do papel e da função de uma certa relação entre as coisas no interior de um sistema”.

Para Davidov (1988, p. 124) o pensamento empírico "assegura às pessoas um amplo campo na discriminação e designação das propriedades dos objetos e suas relações, inclusive as que em um momento determinado não são observáveis, sem que se deduzam, indiretamente, a base de raciocínios".

Diferentemente do pensamento empírico, o pensamento teórico possibilita à pessoa formar uma unidade do discurso, compreendendo o fenômeno em movimento e estabelecendo relações entre as particularidades e assim as operações passam a ser realizadas não mais por representações imediatas do real, mas por conceitos. Para Davidov:

\footnotetext{
${ }^{28}$ Pensamento que se baseia na observação; reflete apenas as propriedades exteriores dos objetos e apóia-se inteiramente nas representações concretas (RUBTSOV, 2003).
} 
o conceito aparece aqui como a forma de atividade mental por meio da qual se reproduz o objeto idealizado e o sistema de suas relações, que em unidade refletem a universalidade ou a essência do movimento do objeto material e como meio de sua representação mental, de sua estruturação, quer dizer, como ação mental especial (DAVIDOV, 1988, p. 126).

A partir disso, entendemos que todo conceito é expressão da "atividade humana", apropriada pela pessoa na interação com outras, uma vez que é coletiva e historicamente construída.

De acordo com Serrão (2004), para que ocorra o desenvolvimento do pensamento teórico das pessoas e principalmente das crianças, é importante organizar o ensino e a educação escolar nessa direção ou ainda segundo Davidov (1988) é preciso organizar a "atividade de estudo" das crianças.

Para Davidov embora sejam muitos os tipos de "atividade" realizadas pelas crianças, a "atividade de estudo" é a principal delas porque "ela determina o surgimento das principais neoformações psicológicas de dada idade, define o desenvolvimento psíquico geral dos escolares de menor idade, a formação de sua personalidade em conjunto" (DAVIDOV, 1988, p. 159).

O estudo é considerado uma "atividade humana" porque a pessoa que o realiza se transforma ao mesmo tempo em que transforma os objetos materiais e simbólicos com os quais interage. Nesse sentido, por meio da "atividade de estudo", atitudes e habilidades de investigação são desenvolvidas nos estudantes, tornando-os capazes de se apropriarem de conhecimentos de um modo semelhante ao que historicamente ocorreu. Por isso, pressupõe a relação e a interação com o outro, não sendo algo possível de ser realizado sozinho.

Em busca de conhecermos um pouco mais sobre a "atividade humana" e agora em específico sobre as "atividades de aprendizagem", buscaremos em Rubtosv e nas suas pesquisas com base na "teoria da atividade" essas informações.

Segundo Rubtsov (2003), o objeto de aprendizagem deve ser o conteúdo dos conhecimentos teóricos, pois para ele, o motivo da aprendizagem é assumir uma atitude de busca de conhecimentos teóricos diante dos problemas a serem resolvidos. Assim ainda para o autor (2003, p. 131) "propor um problema de aprendizagem a um escolar é confrontá-lo com 
uma situação cuja solução em todas as variantes concorrentes pede uma aplicação do método teórico generalista ${ }^{29,}$.

É através de uma atividade concreta que o conteúdo dos conhecimentos é adquirido e que as regras que comandam este processo de aquisição são estabelecidas, ou seja, são estabelecidos os meios pelos quais problemas típicos de uma ou outra atividade podem ser resolvidos, diferente de uma atividade de aprendizagem, na qual os processos de aquisição tornam-se o objeto direto e o problema a ser resolvido por essa atividade (RUBTSOV, 2003).

Para Elkonin $^{30}$ (1971 apud RUBTSOV, 2003, p. 130) de acordo com a periodização tradicional, a atividade de aprendizagem para as crianças entre 6 e 10 anos de idade ${ }^{31}$ é primordial, pois é nessa idade que ela se forma, trazendo novas estruturas psicológicas que determinam particularidades de outras atividades da criança como as brincadeiras, o trabalho, o jogo, nos quais as aprendizagens têm lugar de destaque. Já para os adolescentes, a aprendizagem (os seus estudos) é comandada por um conjunto de atividades sociais como organização, estudos, esportes, lazer, criatividade e o trabalho.

Para compreendermos melhor o que é uma atividade de aprendizagem, faz-se necessário ainda analisar sua estrutura com os seus dois elementos básicos: o problema e a ação.

O processo de resolução de um problema pode ser definido como o da aquisição das "formas de ação gerais" típicas, também chamadas por Rubtsov de "forma de ação universal". Estas formas de ação, designam "aquilo que é obtido como o resultado ou modo de funcionamento essencial para trazer soluções para os problemas de aprendizagem; mais do que soluções, é este resultado particular o objeto desses problemas" (RUBTSOV, 2003, p. $131)$.

Ainda com relação à resolução de problemas de aprendizagem, Rubtsov (2003) destaca a importância de diferenciá-los da resolução de problemas concretos e práticos. Para ele, na resolução desses problemas, o modo de ação é desencadeado por si mesmo, pois se relaciona às próprias condições de realização de tarefas concretas e específicas, não transcendendo à generalização, enquanto o processo de resolução de problemas de aprendizagem apóiam-se em um modo de ação geral ("forma de ação geral” ou "forma de

\footnotetext{
${ }^{29}$ De acordo com Rubtsov (2003), a generalização teórica supõe uma análise das condições de construção iniciais de um sistema de objetos por meio da sua transformação, que permite ao indivíduo, após ter resolvido uma série de problemas concretos e práticos, apropriar-se dos conhecimentos (grifos do autor).

${ }^{30}$ ELKONIN, D. B. The psychology of preschool children. Cambridge, Mass.: MIT Press, 1971.

${ }^{31}$ Período que corresponde hoje à Educação Infantil (6 anos) e ao Ensino Fundamental I ( de 7 a 10 anos) equivalente da $1^{\mathrm{a}}$ a $4^{\mathrm{a}}$ série do ciclo I do Ensino Fundamental e compreendendo assim o período de idade que é o foco de nossa pesquisa ( 9 e 10 anos em média e $3^{\mathrm{a}}$ e $4^{\mathrm{a}}$ série).
} 
ação universal") ou em conhecimentos teóricos para a resolução do problema, que envolve necessariamente ação cognitiva.

Pensando dessa forma, para que as "atividades de aprendizagem" possam ocorrer, fazse necessária uma organização específica do ensino, no sentido de garantir que momentos coletivos possam ocorrer, proporcionando assim o surgimento da "atividade coletiva" ou da "atividade comum". Para Rubtsov:

a aptidão para a aprendizagem é, na verdade, resultado de uma determinada interiorização, de maneira que a atividade de aprendizagem se apresenta, essencialmente, sob a forma de uma atividade realizada em comum, na qual as tarefas são repartidas entre os alunos, ou entre alunos e professor (RUBTSOV, 2003, p. 134).

É necessário que as crianças tenham um adulto ${ }^{32}$ como parceiro para adquirir diversos elementos na ação sobre os quais ainda não têm domínio como a correção ou a avaliação. Para assumir o conjunto dessas funções, segundo Rubtsov (2003), a criança deve ser colocada no lugar do adulto e agir por si própria e para tanto, ela deverá entrar em colaboração com outra criança.

Segundo Garnier, Bednarz e Ulanovsaya, a atividade de aprendizagem na escola:

não está ligada ao desenvolvimento de habilidades específicas, mas, para além do aprendizado de uma habilidade qualquer, consiste em aprender a aprender. Dentro dessa perspectiva, o objetivo do professor é levar a criança a dar forma ao método teórico através do qual um problema pode ser resolvido em uma situação de aprendizagem; esta situação é chamada de problema de aprendizagem (GARNIER; BEDNARZ; ULANOVSKAYA, 2003, p. 14, grifos do autor)

Com isso percebemos a importância dada ao professor na sua tarefa de organizar, desenvolver e avaliar as atividades de aprendizagem dos alunos, de modo que ele possa introduzir as bases necessárias para o desenvolvimento psicológico das crianças, ampliando assim suas possibilidades de ações.

Rubtsov (2003) conclui que a tendência geral do desenvolvimento psíquico da criança a leva, constantemente, do social para o individual, na qual a ação "interpsíquica" transforma-

\footnotetext{
${ }^{32}$ No caso específico da Educação Escolar, o "professor”.
} 
se em ação "intrapsíquica" e a atividade coletiva torna-se uma etapa necessária e um mecanismo interior da atividade individual.

Continuando nossa trajetória, após termos analisado as "atividades de estudo" e as "atividades de aprendizagem" na busca de compreender o ensino como uma "atividade humana" de modo geral, iniciaremos uma reflexão sobre a "atividade orientadora de ensino", elaborada, principalmente, por Manoel Oriosvaldo de Moura e Anna Regina Lanner de Moura.

A “atividade orientadora de ensino", segundo Moura e Lanner de Moura, organiza-se por meio dos seguintes elementos básicos:

- intencionalidade do professor;

- explicitação de uma situação-problema;

- momentos de interação entre as crianças, o professor e as diferentes fontes em busca de possíveis formas de resolução do problema apresentado;

- momentos coletivos de síntese teórica das resoluções encontradas, sob a orientação da história do conceito e da abordagem histórico-cultural do desenvolvimento.

Segundo Moura (1992, p. 68) a "estrutura da atividade orientadora é a da própria gênese do conceito: o problema desencadeador, a busca de ferramentas intelectuais para solucioná-lo, surgimento das primeiras soluções e a busca de otimização destas soluções”.

Com base nos elementos da "atividade de ensino", Moura e Lanner de Moura defendem que na intencionalidade do professor, desencadeada pela necessidade de organizar o ensino com o objetivo principal de favorecer a apropriação de determinados conceitos pelos alunos ("atividade principal"), devem estar presentes os motivos decorrentes dessa necessidade, bem como as ações e as operações correspondentes que levarão ao objetivo proposto.

$\mathrm{Na}$ "atividade orientadora de ensino", uma série de motivos pode dirigir as diferentes ações desencadeadas por caminhos diversos, onde o professor contribui para que não haja desvio dos objetivos, assumindo o papel na disposição das condições que propiciem a aprendizagem. É por isso que a "atividade orientadora de ensino" apresenta em sua própria expressão o termo "orientadora", que é uma qualidade da "atividade de ensino". Nas palavras de Moura: 
Lidar com conhecimentos novos significa lidar com novos conteúdos escolares. A atividade de ensino visa justamente a atingir uma realidade diferente da material imediata. Ela é impactante na realidade psicológica do sujeito que aprende. Ela vai produzir uma mudança nessa realidade por meio de uma ferramenta simbólica. Isso implica a definição de objetivos, por quem ensina, como se fosse parte de uma atividade. É uma necessidade de fazer com que determinados sujeitos se apropriem de certos conhecimentos. É troca de significados. O motivo é a apreensão do novo conteúdo escolar. Esse por sua vez, é o objetivo que exige determinada ação para poder ser veiculado de modo que os sujeitos os apreendam (MOURA, 2000, p. 31).

Quanto à sua realização, a "atividade orientadora de ensino" não deixa estabelecido desde o início quais são os passos que devem ser seguidos rigidamente. O que é definido e o que deve ser seguido, rigorosamente, são os princípios que a norteiam. Quanto à sua estrutura, Moura considera que ela:

tem uma necessidade: ensinar; tem ações: define o modo ou procedimentos de como colocar os conhecimentos em jogo no espaço educativo; e elege instrumentos auxiliares de ensino: os recursos metodológicos adequados a cada objetivo e ação (livro, giz, computador, ábaco, etc.). E por fim, os processos de análise e síntese, ao longo da atividade, são os momentos de avaliação permanente para quem ensina e aprende (MOURA, 2001, p. 155).

O foco de análise da "atividade orientadora de ensino" desenvolvida por Moura (1992, 1996, 2000 e 2001) e Lanner de Moura (1995) está na educação pré-escolar e nos primeiros anos de escolaridade, com ênfase na apropriação do signo numérico e do conhecimento geométrico pelas crianças. Nossa pesquisa, a análise da "atividade orientadora de ensino" também encontra-se nos primeiros anos de escolaridade, especificamente, na $3^{\mathrm{a}}$ e $4^{\mathrm{a}}$ séries do Ensino Fundamental, com foco no desenvolvimento das práticas de Educação Ambiental. Assim, buscamos analisar e compreender os pontos de divergência e/ou convergência dessas práticas com as "atividades orientadoras de ensino".

Consideramos que todo o indivíduo é capaz de aprender e ao aprender, ele se desenvolve e se constitui como ser humano. Para nós, a aprendizagem ocorre necessariamente no campo das interações sociais, especialmente entre crianças e adultos e entre as próprias crianças pela mediação de instrumentos materiais e psicológicos que promovem a formação dos processos psicológicos superiores. Sendo assim, a aprendizagem é concebida como um 
processo complexo, multifacetado e eminentemente histórico-cultural, além de estar dirigido para a apropriação da experiência humana sistematizada.

Acreditamos que o sujeito que aprende sempre está em movimento, está ativo e, portanto, aprende em todo o lugar, porém, a aprendizagem ocorrida na escola é a que propicia mais o desenvolvimento do pensamento teórico, uma vez que a cultura dessa instituição é diferente da realizada no cotidiano, o que faz toda a diferença. Com isso podemos compreender melhor a importância dada ao ensino para o desenvolvimento humano, no qual o papel do outro (que pode ser o próprio professor ou os colegas) é fundamental na aprendizagem.

Para Vigotski, nas atividades realizadas em comum com adultos ou crianças mais velhas, através de um processo de interiorização, as crianças alcançarão o domínio individual de seu próprio pensamento.

O papel do professor no processo de ensino é insubstituível, pois é ele o responsável por criar as situações (os motivos) em que os problemas de aprendizagem se apresentam, instigando e promovendo a atuação dos estudantes em sua zona de desenvolvimento proximal ou potencial ${ }^{33}$, onde os problemas de aprendizagem podem desencadear uma atitude mental ativa dos estudantes, pelo estabelecimento do diálogo interno e de ações compartilhadas com colegas e com o professor.

O destaque dado ao processo de desenvolvimento de práticas de Educação Ambiental desenvolvidas no Ensino Fundamental I e sua aproximação com as "atividades de aprendizagem" e mais especificamente, com as "atividades orientadoras de ensino" encontrase no fato de que este processo deve ter o compromisso com a formação do ser humano como um todo e não apenas do sujeito cognoscente.

\section{EDUCAÇÃO E MEDIAÇÃO}

Segundo Oliveira, Almeida e Arnoni, o processo educativo é constituído de mediações, ou seja, sem mediação não pode haver educação. Então, se há mediação, há

\footnotetext{
33 O conceito de Zona de Desenvolvimento Proximal ou Potencial (ZDP), do original "Zone of Proximal Development", foi criado por Vygotsky e refere-se à distância entre o nível de desenvolvimento real, determinado pela resolução independente de problemas e o nível superior de desenvolvimento potencial, determinado pela resolução de problemas sob a orientação de um adulto ou em colaboração com pares mais capazes. DANIELS, Harry. Vygotsky e a Pedagogia. Tradução Milton Camargo Mota. São Paulo: Loyola, 2003. Poderíamos assim resumir a zona de desenvolvimento proximal como a diferença entre o que o aluno consegue fazer independentemente em seu atual nível de desenvolvimento e o que ele pode fazer com a ajuda de um adulto.
} 
necessariamente, dois termos opostos e não-antagônicos, um no plano do imediato e outro no mediato. Assim:

\footnotetext{
quem está no plano do imediato é o aluno e quem está ou deveria estar no plano do mediato é o professor. Cabe-nos esclarecer que o imediato não é mais pobre nem inferior ao mediato, portanto o mediato não é mais rico, melhor ou superior ao imediato; eles são estados distintos e opostos (não-antagônicos) entre si. Dessa forma, as relações entre o professor e os alunos não podem ser hierárquicas, nem de dominação, por um lado, nem de subordinação, por outro. Eles devem ter por base o esforço de mediação, que não é nem automática nem espontânea (OLIVEIRA, ALMEIDA e ARNONI, 2007, p.108-109).
}

Os alunos vivem o plano do imediato e na maior parte dos casos permaneceriam nele não fosse a relação educativa. Dessa forma, cabe ao professor fazer com que eles superem o plano imediato no mediato, ou seja, tenham acesso ao conhecimento produzido historicamente pela humanidade. $\mathrm{Na}$ aula, os alunos também se encontram no imediato, uma vez que eles geralmente sabem como a aula ocorrerá. Por outro lado, o professor deve ter clareza do que vai ensinar naquela aula, pois se ele não sabe o que vai desenvolver, ambos (professor e alunos) permanecerão no plano do imediato e a aula ficará restrita à solução de problemas comportamentais e disciplinares.

Para Oliveira, Almeida e Arnoni (2007), o cotidiano que é imediato, é também concreto, ou seja, é uma totalidade indivisível. Segundo eles, para que a mediação propicie a superação do imediato no mediato é necessário que ocorram dois processos onde imediato e mediato se relacionam dialeticamente:

1) a negação do concreto (cotidiano) pelo abstrato, que implica separar o todo em partes para compreendê-lo por meio delas e;

2) a negação do abstrato pelo concreto, agora concreto pensado, ou seja, para chegar à compreensão do todo é preciso negar o entendimento das partes.

Sem a interferência deliberada dos professores, no caso da educação escolar, ou de orientadores, na educação não-escolar, tal abstração não se realiza, pois o aluno ou o aprendiz não supera essas dificuldades sozinho. Eles podem até receber a ajuda de colegas, porém a tarefa de organizar esse processo é uma tarefa dos professores, cuja responsabilidade não 
termina aí, pois ainda é preciso fazer com que eles (os alunos) superem o abstrato no concreto pensado.

De acordo com Oliveira, Almeida e Arnoni (2007) o esforço do professor, que está no plano do mediato, é o trazer o estudante para este plano. Ele pode e deve mediar com seus alunos e garantir as condições para que o estudante medeie com ele $\mathrm{O}$ aluno que quase sempre está confortável no imediato, tenta trazer o professor para esse campo. Assim é esse jogo de forças, regido pelo momento predominante ${ }^{34}$, no qual ora os conflitos são velados ora são explícitos, que possibilita a mediação.

No capítulo a seguir, apresentaremos uma caracterização do nosso universo de pesquisa e uma reflexão metodológica, destacando e justificando nossos procedimentos e instrumentos de pesquisa.

\footnotetext{
${ }^{34}$ momento que ocorre nas relações de mediação, em que um pólo se sobressai em relação ao outro
} 


\title{
CAPÍtULLO II
}

\section{PRÁtiCAS DE EDUCAÇÃO AMBIENTAL NAS ESCOLAS DE ENSINO FUNDAMENTAL I DA DIRETORIA DE ENSINO CENTRO SUL}

\begin{abstract}
“... se dois homens vêm andando por uma estrada, cada um carregando um pão, $e$, ao se encontrarem, eles trocam os pães, cada homem vai embora com um; porém se os dois homens vêm andando pela estrada, cada um carregando uma idéia, e, ao se encontrarem, eles trocam as idéias, cada homem vai embora com duas".
\end{abstract}

Mario Sérgio Cortella

\section{CARACTERIZAÇÃO DA ÁREA E DAS ESCOLAS ENVOLVIDAS NA PESQUISA}

Como já destacamos anteriormente, esta pesquisa abrange algumas escolas de Ensino Fundamental I da Secretaria da Educação do Estado de São Paulo, pertencente à Coordenadoria de Ensino da Região Metropolitana da Grande São Paulo (COGSP), na Diretoria de Ensino Centro Sul.

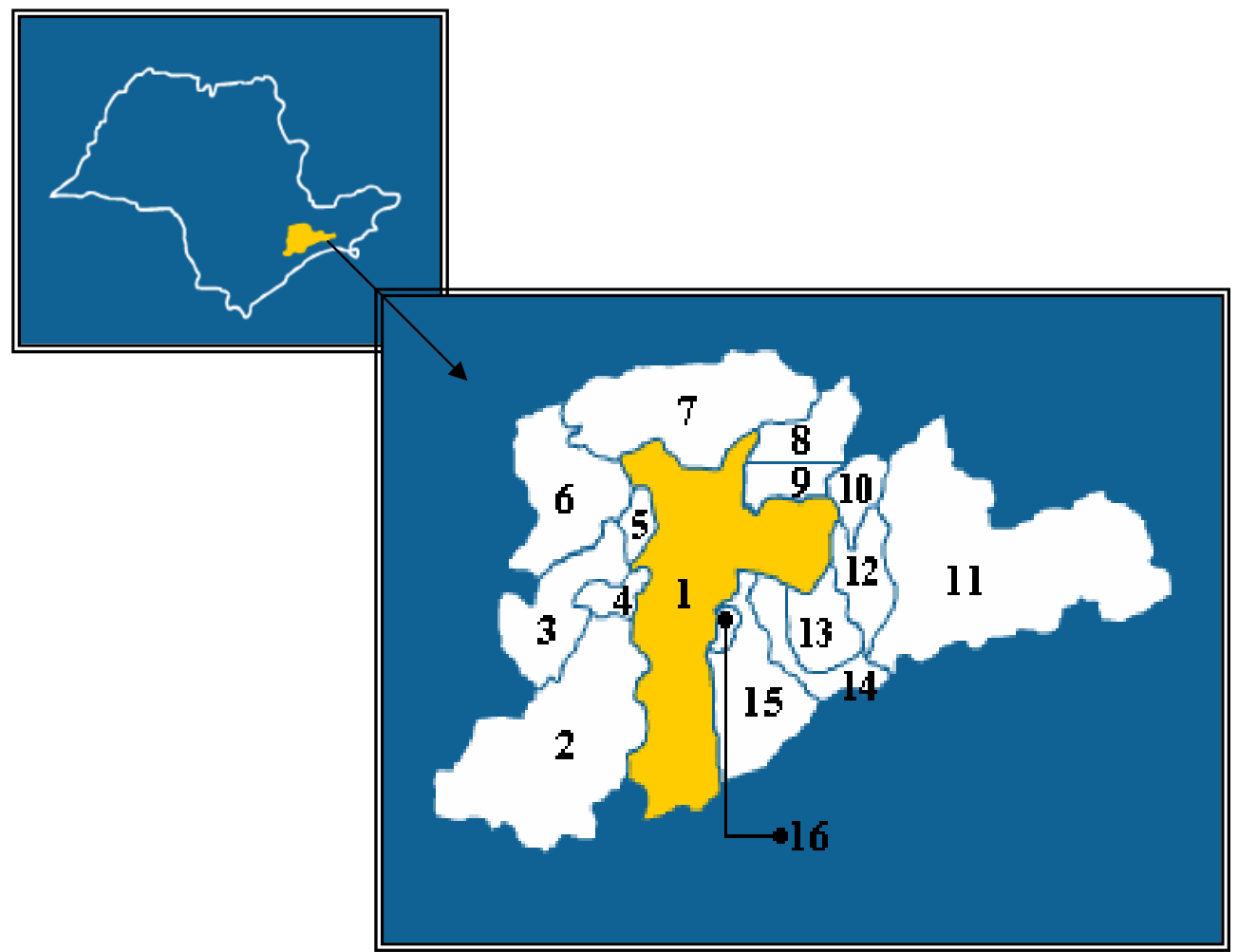

Mapa 01 - COGSP com suas Diretorias: 1- Diretorias da Capital, 2- Itapecerica da Serra, 3- Carapicuíba, 4- Taboão da Serra, 5- Osasco, 6- Itapevi, 7- Caieiras, 8- Guarulhos Norte, 9- Guarulhos Sul, 
10- Itaquaquecetuba, 11- Mogi das Cruzes, 12- Suzano, 13- Mauá, 14- Santo André, 15- São Bernardo do Campo, 16- Diadema.

Dentre as Diretorias de Ensino da Capital, destacamos a Diretoria Centro Sul, que coordena as escolas nas quais desenvolvemos a pesquisa.

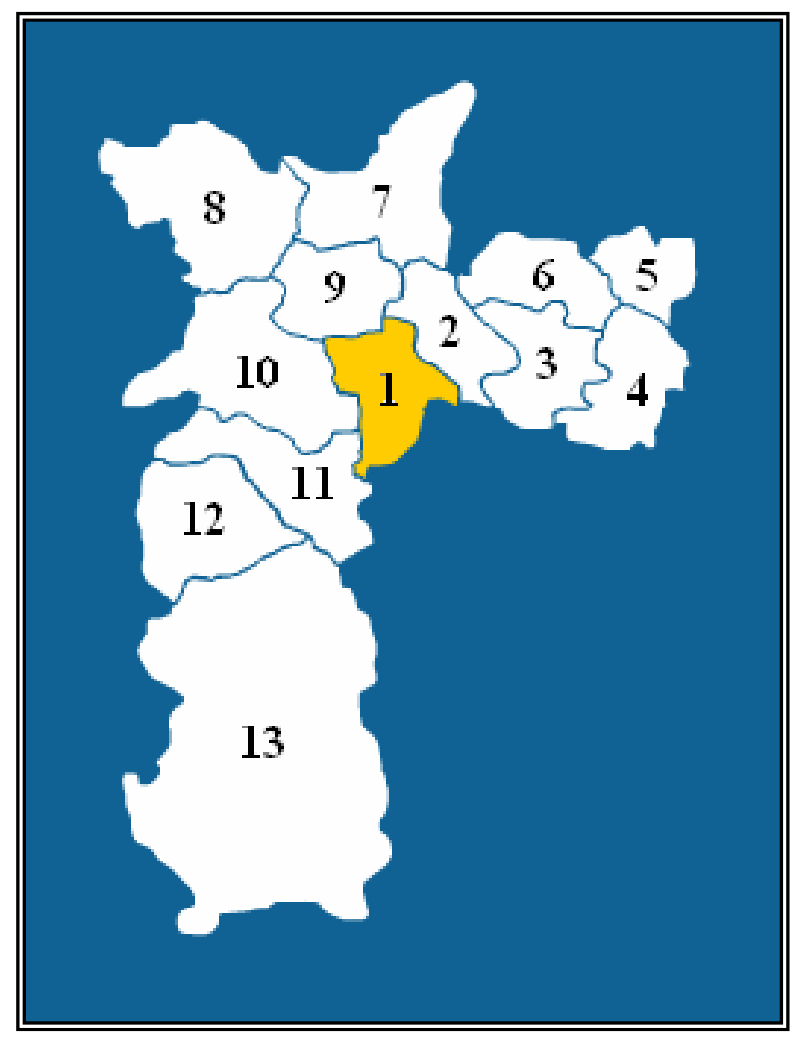

Mapa 02 - Diretorias da Capital: 1- Centro Sul, 2- Leste 5, 3- Leste 4, 4- Leste 3, 5- Leste 2, 6- Leste 1, 7- Norte 2, 8- Norte 1, 9-Centro, 10-Centro Oeste, 11- Sul 1, 12- Sul 2, 13- Sul 3.

As razões de nossa escolha por trabalhar com tais escolas, justificam-se principalmente pelo fato de o pesquisador pertencer a esta Diretoria de Ensino (o seu lugar sócio-histórico), enquanto professor na disciplina de Biologia, além da facilidade em se relacionar com os Assistentes de Trabalho Pedagógico (ATPs) das áreas de Ciências e Biologia e de Ensino Fundamental. Relacionamento este, que tem sido bastante importante para o desenvolvimento da nossa pesquisa, principalmente com o ATP responsável pelas disciplinas de Ciências e Biologia.

Atualmente, a Diretoria de Ensino Centro Sul é responsável por 72 escolas públicas, tanto de Ensino Fundamental I e II como de Ensino Médio. Deste universo, 68 oferecem Ensino Fundamental, sendo que 27 delas oferecem apenas o Ensino Fundamental II ( $5^{\mathrm{a}}$ a $8^{\mathrm{a}}$ séries), 14 o Ensino Fundamental I e II ( ${ }^{\mathrm{a}}$ a $8^{\mathrm{a}}$ séries) e 27 exclusivamente o Ensino 
Fundamental I ( $1^{\mathrm{a}}$ a $4^{\mathrm{a}}$ série). Sendo assim, nosso universo de pesquisa compreende 41 escolas.

Como pesquisamos as práticas de Educação Ambiental desenvolvidas por essas escolas, acreditamos ser importante apresentar uma caracterização econômica, social e cultural tanto dessas unidades escolares (UEs) como dos discentes. Para isso, fizemos uma análise nos Planos de Gestão ${ }^{35}$ que contemplam tais informações. Algumas escolas não disponibilizaram o referido documento para análise. Assim os dados aqui apresentados resultam de uma pesquisa realizada pela própria escola, ou das informações passadas pelos próprios professores, não havendo nenhuma interferência ou alteração do pesquisador.

Com o objetivo de facilitar essa análise agrupamos estas UEs em quatro grupos de acordo com sua localização geográfica. Assim, temos o grupo 01 que abrange as UEs 01, 04, 09 e 13, todas pertencentes aos bairros Paraíso, Liberdade e Cambuci. O grupo 02, formado pelas UEs 08, 10 e 17, pertencentes aos bairros Vila Mariana e Saúde. O grupo 03, formado pelas UEs 05, 06, 11, 15 e 16, pertencentes aos bairros Ipiranga e Vila Prudente e o grupo 04, formado pelas UEs 02, 03, 07, 12, 14 e 18, pertencentes aos bairros Cursino e Sacomã.

\section{GRUPO 01}

UE 01 - A grande maioria dos alunos desta UE pertence a uma classe econômica entre média e baixa, tendo vários alunos oriundos de escolas particulares da região.

Com relação à escolaridade dos pais, a maioria tem o ensino médio completo e vários o ensino superior.

Segundo a escola, muitas mães apresentam uma dupla jornada de trabalho o que dificulta o acompanhamento da vida escolar dos filhos.

O bairro apresenta uma boa infra-estrutura e os alunos têm como opções de lazer Shopping Center, igrejas e algumas praças, além de se localizar nas proximidades da avenida Paulista, com várias outras opções de passeio e cultura.

UE 04 - A maioria dos alunos desta UE pertence a uma classe econômica baixa, com raras exceções, tendo um grande número de alunos que residem em "pensões", caracterizadas como cortiços.

\footnotetext{
${ }^{35}$ Plano elaborado pela unidade escolar com duração média de 2 a 5 anos, que contém todos os dados referentes à escola, desde a descrição do espaço físico, mobília, quadro de funcionários, horários de funcionamento, regimento escolar, caracterização dos docentes e discentes, planejamentos por disciplina, planos de avaliação e recuperação, projetos a serem desenvolvidos, ações que aproximem a comunidade da escola e outros.
} 
Quanto à escolaridade dos pais, a maioria apresenta apenas o Ensino Fundamental incompleto até a $4^{\mathrm{a}}$ série, poucos o Ensino Médio e uma porcentagem ainda menor o ensino superior completo.

Segundo a escola, o número de pais que ajudam seus filhos nas lições de casa vem diminuindo a cada ano, o que pode ser justificado pela exaustiva jornada de trabalho, a desestruturação familiar e até mesmo pelo desemprego.

UE 09 - Grande parte dos alunos desta UE possui um nível sócio econômico entre médiobaixo e baixo. Vários alunos são oriundos de escolas particulares da comunidade, devido à dificuldade dos pais em continuarem pagando as mensalidades.

Segundo a escola, a maioria reside em casas alugadas, o que faz com que a rotatividade dos alunos seja muito alta, pois eles se mudam com freqüência.

Quanto às atividades profissionais exercidas pelos pais, observa-se uma variedade muito grande, mas mesmo assim ainda há um número bastante expressivo de desempregados. Cerca de $20 \%$ das mães apresentam dupla jornada de trabalho, o que dificulta o acompanhamento da vida escolar dos filhos.

Há um predomínio de famílias do Norte e Nordeste do país em relação às famílias paulistas. O bairro possui uma boa infra-estrutura e quanto ao lazer, os alunos têm como alternativas: Shopping Center, Igrejas e o Parque da Aclimação, bastante conhecido na região.

UE 13 - A maioria dos alunos desta escola pertence a uma classe econômica baixa e residem em casas de aluguel, o que segundo a escola pode justificar a alta rotatividade dos alunos.

A maioria dos pais tem apenas o ensino fundamental, outros também o ensino médio. A escola enfrenta sérios problemas de comportamento dos alunos e dificilmente recebe apoio e ajuda dos pais, tanto para essas questões, como nas atividades escolares para serem realizadas em casa.

Quanto ao lazer, devido aos baixos recursos financeiros, este resume-se nas atividades proporcionadas pelas igrejas do bairro.

\section{GRUPO 02}

UE 08 - A comunidade onde fica a escola é formada basicamente por uma classe média, cuja atividade econômica predominante é a prestação de serviços, com destaque na atividade hospitalar, visto que a escola está localizada próxima de vários hospitais, mas a maioria dos 
alunos desta UE são filhos de diaristas, zeladores, faxineiras, funcionários de hospitais e, portanto, sem grandes recursos financeiros e acesso a atividades culturais e de leitura.

UE 10 - A clientela desta UE tem origem bastante diversificada, pois muitos residem longe da escola e por isso utilizam o transporte escolar e coletivo. Outra parcela significativa de alunos é proveniente de uma comunidade bastante carente constituída por um Conjunto Habitacional (Cingapura) e por uma favela.

Segundo a escola, a maioria tem casa própria e verifica-se uma grande participação das mulheres no orçamento familiar, o que segundo a escola tem interferido no aproveitamento escolar de muitos alunos devido à falta de assistência em casa. Outro dado importante refere-se ao número insuficiente de creches existentes na região para atender as necessidades da comunidade.

Quanto ao nível cultural, este é satisfatório, mas poderá ser melhorado principalmente com incentivo à leitura. Em relação ao lazer, a escola fica próxima do SESC Ipiranga, ao SESI, Museus de Zoologia e Paulista da USP e de um Shopping Center.

UE 17 - Esta escola atende alunos que pertencem a uma classe econômica média e recebe com frequiência alunos vindos de escolas particulares.

Os pais na sua maioria têm o ensino médio e vários com o ensino superior. $\mathrm{O}$ acompanhamento escolar dos filhos pelos pais é bom, mas segundo a escola pode melhorar com mais incentivo à leitura.

Quanto ao lazer, a escola destaca o Shopping Center, praças e o SESC Vila Mariana.

\section{GRUPO 03}

UE 05 - Esta escola atende alunos de classe econômica baixa, sendo muitos moradores de uma favela localizada nas proximidades.

Os pais na sua maioria têm apenas o ensino fundamental incompleto, o que segundo a escola dificulta bastante o acompanhamento dos pais nas atividades escolares dos filhos, principalmente com relação ao incentivo à atividades extras, como leituras.

Nas proximidades da escola encontra-se o SESC Ipiranga, o SESI, e os Museus de Zoologia e do Ipiranga, que são locais onde os alunos podem realizar atividades aos finais de semana e até mesmo com a escola em atividades programadas. 
UE 06 - Os alunos desta UE são provenientes principalmente dos bairros da Vila Alpina, Vila Bela e Vila Califórnia. A maioria dos alunos é natural da própria cidade de São Paulo, embora muitos sejam filhos de imigrantes nordestinos. Uma parcela significativa vive em cortiços com pouco espaço de circulação e outros são provenientes de um dos abrigos do bairro, vivendo em regime de internato.

Segundo a UE, os alunos de maneira geral apresentam alguns problemas de conduta social como falta de respeito ao espaço do outro, não cumprimento das regras de participação e colaboração, a não aceitação dos direitos e deveres. Enfim, problemas relacionados com a convivência coletiva, o que tem gerado uma indisciplina de forma geral. Os pais na sua maioria são assalariados, com escolaridade mínima e não acompanham as tarefas de seus filhos por falta de tempo ou de estudo, o que tem levado uma parcela significativa dos alunos a apresentarem dificuldades no processo de ensino aprendizagem. Segundo a escola, o lazer dos alunos se constitui basicamente em assistir televisão, brincar na rua e ir ao Carrefour Supermercados.

A comunidade local praticamente não contribui em nada para a melhoria da qualidade da escola, principalmente no seu estado físico, pichando os muros e jogando lixo ao seu redor.

UE 11 - Os alunos desta escola pertencem a uma classe econômica média e a maioria tem casa própria.

Os pais apresentam uma boa formação e contribuem bastante com as atividades escolares, principalmente estimulando a leitura, o que para a escola é muito importante.

Quanto ao lazer, a escola destaca o Museu do Ipiranga, o SESC e algumas praças do bairro.

UE 15 - Esta escola atende alunos na sua maioria de classe média-baixa. Muitos não têm casa própria, o que segundo a escola pode justificar a alta rotatividade dos alunos, dificultando muito a aprendizagem dos mesmos.

Segundo a escola, as mães na sua maioria trabalham fora para ajudar na renda familiar, não tendo assim muito tempo para acompanhar a vida escolar dos filhos. Em alguns casos, há a necessidade de várias convocações para algum responsável comparecer na escola.

Quanto ao lazer, este se resume principalmente em atividades oferecidas pelas igrejas e pela associação de bairro. 
UE 16 - Esta UE fica em um bairro periférico da cidade, fazendo divisa com o município de São Caetano e pertencendo a zona leste de São Paulo. A clientela na sua maioria, pertence à classe média-baixa, sendo que muitos residem em cortiços.

Uma grande parte das famílias não possui casa própria e vive de aluguel, o que segundo a escola faz com que a rotatividade de alunos seja muito alta, pois as famílias se mudam constantemente, o que dificulta a aprendizagem dos alunos e a interação das famílias com a escola.

A participação da comunidade e, principalmente, dos pais na escola é bastante pequena, havendo em alguns casos a necessidade de convocá-los para aparecerem na escola.

Existe apenas uma creche no bairro que não dispõe de vagas suficientes, o que dificulta muito a vida de algumas famílias, principalmente daquelas em que as mães precisam ajudar no orçamento familiar.

Quanto ao lazer, a comunidade dispõe de algumas praças, clube recreativo com quadras poliesportivas, salas de jogos e academia de capoeira. A paróquia da comunidade e outras igrejas também costumam proporcionar atividades e oferecer cursos.

\section{GRUPO 04}

UE 02 - Os alunos desta escola são provenientes de classe média-baixa e de uma comunidade com um alto índice de criminalidade.

Os pais na sua grande maioria apresentam apenas o ensino fundamental e em muitos casos ainda incompleto.

A participação dos pais na vida escolar dos filhos é pequena e essa é uma preocupação da escola; tentar trazer a comunidade para participar das atividades escolares.

Quanto ao lazer, a escola destaca o Zoológico e o Jardim Botânico pela sua proximidade.

UE 03 - Os alunos desta escola pertencem a uma classe econômica média-baixa. Os pais na grande maioria têm apenas o ensino fundamental e médio.

Para a escola, a participação dos pais nas atividades escolares é muito baixa, o que segundo ela, justifica a dificuldade de aprendizagem de alguns alunos.

O bairro não apresenta opções de lazer e por isso é muito comum os alunos procurarem a escola no período em que não estão em aula para utilizarem a quadra poliesportiva. 
UE 07 - Esta escola fica muito próxima da UE 03 e por isso, além de apresenta as mesmas características, ressalta os sérios problemas relacionados com a indisciplina dos alunos. Para a escola, esses problemas de indisciplina relacionam-se com falta de participação dos pais na vida escolar dos alunos.

UE 12 - Esta escola atende alunos de classe média. Os pais apresentam uma boa escolaridade, sendo que muitos deles têm curso superior.

A participação dos pais na vida escolar dos alunos é boa, mas a escola destaca que ainda precisa melhorar e por isso procura realizar atividades que atraiam os pais.

O bairro não apresenta opções de lazer e para isso as famílias acabam se deslocando para outros locais como no bairro do Ipiranga e da Aclimação.

UE 14 - Os alunos que freqüentam esta escola pertencem a uma classe econômica baixa. Os pais apresentam um baixo índice de escolaridade e de participação nas atividades escolares.

Dentre as principais dificuldades apontadas pela escola, encontram-se as relacionadas com a indisciplina dos alunos, o que segunda ela dificulta muito o desenvolvimento do currículo escolar e a aprendizagem dos alunos.

O bairro não apresenta opções de lazer e por isso quando os alunos não estão na escola, acabam ficando na rua ou em casa vendo tv.

UE 18 - Os alunos atendidos por essa escola residem no próprio bairro e nas suas imediações. Mudam-se com grande freqüência, o que gera um número bastante alto de transferências durante o ano letivo, além de problemas de comunicação. A clientela na sua maioria pertence à classe média-baixa, exercendo atividades profissionais variadas como pedreiros, marceneiros, ambulantes, cobradores e motoristas de ônibus.

A maioria dos pais são separados, o que para a escola gera sérios problemas de aprendizagem e emocionais.

Quanto às atividades culturais, estas se resumem à escola e às igrejas. Os pais não costumam acompanhar a vida escolar de seus filhos e dificilmente comparecem na escola.

UE 19 - Esta escola fica muito próxima a UE 14 e por isso apresenta as mesmas características, além de destacar o problema relacionado com a falta de participação dos pais nas atividades escolares dos filhos, o que segundo ela compromete seriamente na aprendizagem dos alunos. 
A partir dessa pequena caracterização, podemos observar que as escolas na sua maioria, apresentam as mesmas dificuldades, principalmente com as relacionadas à falta de participação dos pais nas atividades escolares e com a indisciplina dos alunos.

Apesar de o Plano de Gestão escolar ser um documento de domínio público devendo estar disponível a todos da comunidade, observamos principalmente por parte de alguns Diretores, uma certa resistência na apresentação deste documento para análise, até mesmo para os professores da própria escola. Em alguns casos, as professoras desconheciam a existência de tal documento.

Acreditamos que a participação de todos - diretores, coordenadores, professores, funcionários, pais e alunos - na elaboração deste documento é de fundamental importância, uma vez que ele trata da vida da escola, dos seus planejamentos, dos planos de avaliação, recuperação e dos projetos a serem desenvolvidos num determinado período, garantido assim a continuidade nos trabalhos escolares. Acreditamos que a construção deste documento tiver a participação de todos na sua elaboração, desenvolvimento e avaliação, muitos dos problemas relatados serão solucionados ou minimizados.

\section{A PESQUISA QUALITATIVA NA PERSPECTIVA SÓCIO-HISTÓRICA.}

As investigações de natureza qualitativa no âmbito das ciências humanas sob a orientação da abordagem sócio-histórica apóiam-se principalmente nas idéias de Vigotski, Luria e Baktin. Nessa perspectiva, a compreensão dos fenômenos ocorre a partir de seu acontecer histórico, no qual o particular é considerado uma instância da totalidade social. Assim, a pesquisa é vista como uma relação entre sujeitos e, portanto, dialógica onde o pesquisador é parte integrante do processo investigativo.

Para Kosík:

A compreensão das coisas e do seu ser, do mundo nos fenômenos particulares e na totalidade, é possível para o homem na base da abertura que eclode na práxis. $\mathrm{Na}$ práxis e baseado na práxis, o homem ultrapassa a clausura da animalidade e da natureza inorgânica e estabelece a sua relação com o mundo como totalidade (KOSÍK, 1995, p.227). 
Como a perspectiva sócio-histórica tem o materialismo dialético ${ }^{36}$ como seu pano de fundo, esta expressa em seus métodos as marcas de sua filiação dialética, uma vez que a dialética insiste na relação dinâmica entre o sujeito e o objeto no processo de conhecimento. Ela valoriza a contradição dinâmica do fato observado, a atividade criadora do sujeito que observa as oposições contraditórias entre o todo e a parte, e os vínculos do saber e do agir com a vida social dos homens.

Para Oliveira, Almeida e Arnoni (2007) a mediação dialética constitui o pressuposto teórico-filosófico que possibilita compreender as relações de tensão que se estabelecem no processo de ensino e no de aprendizagem. É entendida como uma relação dialética (força de tensão) que tem por referência a diferença, a heterogeneidade, a repulsão e o desequilíbrio entre seus termos, ou seja, o saber imediato (conhecimento comum) e o saber mediato (conhecimento crítico e dialético).

A investigação dialética da realidade social tem como pressuposto que cada fenômeno pode ser compreendido como momento do todo. Um fenômeno social para o autor, é um fato histórico na medida em que é examinado como momento de um determinado todo e desempenha, portanto, uma função dupla: de um lado, definir a si mesmo, e de outro, definir o todo.

O objeto das Ciências Sociais é histórico. Significa que as sociedades humanas existem num determinado espaço, num determinado tempo, que os grupos sociais que a constituem são mutáveis e que tudo, instituições, leis, visões de mundo são provisórios, passageiros, estão em constante dinamismo e potencialmente tudo está para ser transformado.

Para Frigotto (1995), delimitar um objeto para a investigação não é fragmentá-lo, ou limitá-lo arbitrariamente. Ou seja, se o processo de conhecimento nos impõe a delimitação de um determinado problema, isto não significa que tenhamos que abandonar as múltiplas determinações que o constituem. Assim, mesmo delimitado, um fato teima em não perder o tecido da totalidade de que faz parte indissociável. Ainda de acordo com o autor, para tornarse dominante uma concepção de totalidade concreta de conhecimento é preciso que essa totalidade vá se concretizando no plano da produção da vida social, o que quer dizer que ela é ao mesmo tempo, um problema ético-político, econômico, cultural e epistemológico. Assim iremos perceber a complexidade do desafio a enfrentar quando temos a convicção ético-

\footnotetext{
${ }^{36}$ Dentro da perspectiva marxista como sociologia do conhecimento, os princípios fundamentais que explicam o processo de desenvolvimento social podem ser resumidos nos termos: materialismo histórico e materialismo dialético, onde o histórico representa o caminho teórico que aponta a dinâmica do real na sociedade e a dialética refere-se ao método de abordagem deste real.
} 
política da necessidade de lutarmos em todos os planos para suplantar as relações sociais de alienação e exclusão.

Segundo Molon (2005) a perspectiva sócio-histórica constitui-se como um enfoque teórico-metodológico profícuo para a área da Educação e promissor para a Educação Ambiental, pois possibilita a discussão e a análise das dimensões epistemológicas, ontológicas, metodológicas e das expectativas e perspectivas educacionais.

O debate epistemológico faz-se necessário, pois precisamos perguntar sobre o tipo de conhecimento que produzimos, se é adaptativo e exclusivo ou conflitivo e complexo (adquire significado na totalidade), qual a sua natureza, se é emancipadora ou alienadora, se reproduzimos a repetição e a mesmice ou mudamos e transformamos a realidade social, se nos comprometemos ou não em promover uma vida mais digna e justa. Fazemos algumas perguntas, mas muitas outras ainda são necessárias.

Quanto à natureza alienadora do tipo de conhecimento que produzimos, dentre as inúmeras análises e implicações da Teoria da Atividade feitas por Leontiev, destaca-se o enriquecimento dos instrumentos metodológicos de análise dos processos de alienação produzidos pelas atividades de que dão o sentido (ou o sem-sentido) da vida dos seres humanos na sociedade capitalista, pois essa não consideração poderia operar segundo o autor uma assepsia ideológica, descaracterizando-a de sua explicita e consistente filiação filosófica ao marxismo.

Duarte considera impossível trabalhar com a teoria da atividade de maneira coerente com seus pressupostos básicos se essa questão da alienação produzida pela sociedade de classes não tiver no centro das análises teóricas e práticas que venham a ser desenvolvidas. Quando "ignora-se a questão da alienação da atividade de trabalho na sociedade capitalista, a teoria da atividade perde todo o seu potencial crítico e se reduz a uma variante da assim chamada pesquisa etnográfica" (DUARTE, 2003, p. 6).

A pesquisa qualitativa nas Ciências Sociais se preocupa com um nível de realidade que não pode ser quantificado, ou seja, ela trabalha com um universo de significados, motivos, aspirações, crenças, valores e atitudes, o que corresponde a um espaço mais profundo das relações, dos processos e dos fenômenos que não podem ser reduzidos à operacionalização de variáveis.

Quando orientada pela perspectiva sócio-histórica, a pesquisa qualitativa baseia-se na tentativa de superar os reducionismos das concepções empíricas e idealistas, na qual sua preocupação está em encontrar métodos de estudar os homens como unidade de corpo e mente, ser biológico e ser social, membro da espécie humana e participante do processo 
histórico (datados, concretos, marcados por uma cultura e que ao produzirem e reproduzirem a realidade social, são ao mesmo tempo, produzidos e reproduzidos por ela).

Segundo Vygotsky (1991), um método reflete sempre um olhar, uma perspectiva que se tem das questões a serem estudadas, na qual a preocupação do pesquisador deve ser maior com o processo em observação do que com o seu produto, uma vez que os fenômenos humanos devem ser estudados em seu processo de formação e mudança, ou seja, em seu aspecto histórico.

Nessa perspectiva, destaca-se a preocupação de se compreender os eventos investigados, descrevendo-os e procurando suas possíveis relações, integrando o individual com o social. Assim, a observação não deve se limitar à pura descrição de fatos singulares, uma vez que seu verdadeiro objetivo é compreender como uma coisa ou acontecimento se relaciona com as outras coisas e acontecimentos. Ela é um encontro de muitas vozes, pois ao se observar um evento, depara-se com diferentes discursos verbais, gestuais e expressivos.

Para o enfoque sócio-histórico, o método é uma questão central e essencial, isto é, não é visto como algo a priori nem a posteriori ao processo de investigação, mas algo que é simultaneamente pré-requisito e produto, instrumento e resultado do estudo. Para Vigotski, o método é indispensável e constitutivo de todo o processo de conhecer.

Nesse sentido, o método não é a causa do conhecimento. A metodologia ${ }^{37}$ proposta é conhecer pelas causas, sendo que o mais importante é buscar a gênese, a origem. Desse modo, podemos dizer que Marx, além de outros autores, iluminam essa perspectiva, pois eles estavam interessados nos seus trabalhos nos processos e na gênese dos fenômenos.

De acordo com Luria ${ }^{38}$ (1983 apud FREITAS, 2002) a abordagem científica tradicional quantitativa é fundamentalmente limitada com respeito à vida. Para ele, a ciência tem que ter algo mais, um complemento indispensável: a arte tem de entrar na ciência, na qualidade de arte da descrição.

O pesquisador é parte fundamental na pesquisa qualitativa na qual ele deve preliminarmente, se despojar de todos os preconceitos, predisposições para assumir uma atitude aberta a todas as manifestações que observa, sem adiantar explicações nem se conduzir pelas aparências imediatas, a fim de alcançar uma compreensão global dos fenômenos. Ele não é um ser humano genérico, mas um ser humano social que faz parte da

37 Compartilhando das idéias de Minayo (1996), entendemos por metodologia o caminho e o instrumental próprios de abordagem da realidade. Assim, ela ocupa lugar central no interior das teorias sociais, pois faz parte intrínseca da visão social de mundo veiculada na teoria. Inclui as concepções teóricas de abordagem, o conjunto de técnicas que possibilitam a apreensão da realidade e também o potencial criativo do pesquisador.

${ }^{38}$ LURIA, A. R. Uno Sguardo sul passato: considerazione retrospettive sulla vita di uno psicólogo soviético. Firenze: Giunti Barbèra, 1983. 
investigação e leva para ela tudo aquilo que o constitui como um ser concreto em diálogo com o mundo em que vive. Por isso, pode-se dizer que o pesquisador é um dos principais instrumentos da pesquisa, porque se insere nela e a análise que faz depende da sua situação pessoal-social.

Quando nos esforçamos para conhecer determinado aspecto ou fato das múltiplas práticas e relações sociais que os homens estabelecem num determinado tempo, numa determinada cultura, percebemos que mediata ou imediatamente o sujeito que busca conhecer este aspecto da realidade está nela implicado.

A respeito da relação do pesquisador com seu objeto de estudo, Freitas diz que nas ciências naturais:

\footnotetext{
seu objeto de estudo é o homem, "ser expressivo e falante". Diante dele, o pesquisador não pode se limitar ao ato contemplativo, pois encontra-se perante um sujeito que tem voz, e não pode apenas contemplá-lo, mas tem de falar com ele, estabelecer um diálogo com ele (FREITAS, 2002, p. 24).
}

Nesse sentido, a relação entre o pesquisador e seu objeto de estudo, pode ser considerada como uma relação entre sujeitos numa perspectiva dialógica.

Ao apontar para uma relação entre sujeitos, a abordagem sócio-histórica, sugere que os professores precisam ser considerados como parceiros do pesquisador. O pesquisador, além de sujeito na pesquisa qualitativa, também é um sujeito intelectual ativo no curso da investigação.

Nessa perspectiva, tudo muda em relação à pesquisa, uma vez que o investigador e o investigado são dois sujeitos em interação, onde o homem não é apenas um objeto de explicação, mas deve ser compreendido num processo que supõe duas consciências, dois sujeitos e, portanto, “dialógico”. Para Chizzotti (2003), cria-se uma relação dinâmica entre o pesquisador e o pesquisado que não será desfeita em nenhuma etapa da pesquisa até seus resultados finais, pois esta relação viva é indispensável para se apreender os vínculos entre as pessoas e os objetos, e os significados que são construídos pelos sujeitos.

Uma das grandes contribuições da perspectiva sócio-histórica é potencializar o diálogo com as diversas áreas do conhecimento em abordagens interdisciplinares e transdisciplinares, promovendo novos modos de produção e apropriação do saber, do sentir e do fazer, modos esses já destacados por nós em momento anterior. 
Em uma pesquisa qualitativa orientada pela perspectiva sócio-histórica, o pesquisador faz parte da própria pesquisa, onde suas ações e seus efeitos também constituem elementos de análise, pois não existe neutralidade. Segundo Freitas (2002, p. 25-26) de acordo com Baktin, “o critério que se busca em uma pesquisa não é a precisão do conhecimento, mas a profundidade da penetração e a participação ativa tanto do investigador quanto do investigado". Com base nessas idéias, podemos concluir que o investigador durante o seu processo de pesquisa também está em processo de aprendizagem e transformação, assim como o pesquisado ${ }^{39}$ que pode refletir, aprender e ressignificar-se no processo de pesquisa, uma vez que ele não é tido como um objeto.

Dentro dessa proposta que estamos desenvolvendo, a metodologia adota a perspectiva da totalidade, na qual ao valorizar os aspectos descritivos e as percepções pessoais, devemos focalizar o particular como instância da totalidade social, procurando compreender também o contexto. Desse modo, não se investiga em razão de resultados, mas o que se quer obter é uma compreensão dos comportamentos a partir da perspectiva dos sujeitos da investigação.

Quanto às questões formuladas para a pesquisa, estas não são estabelecidas a partir da operacionalização de variáveis, mas se orientam para a compreensão dos fenômenos em toda a sua complexidade e em seu acontecer histórico, uma vez que segundo Vigotski, a conduta humana não é apenas o produto da evolução biológica, mas também o produto do desenvolvimento histórico e cultural. Assim, ao estudar o homem é necessário compreendê-lo a partir da interação dialética dessas duas linhas de desenvolvimento, ou seja, a natural e a biológica.

Com relação à entrevista, esta também é marcada por uma dimensão social, pois não se reduz a uma troca de perguntas previamente preparadas, mas é concebida como uma produção de linguagem e, portanto, dialógica. É o sujeito que se expressa, mas sua voz carrega o tom de outras vozes, refletindo a realidade de seu grupo, gênero, etnia, classe, momento histórico e social. Aquilo que compartilham entre si revelar-se-á mais claramente quando cada um puder falar de suas expectativas, mais do que quando observado em suas atividades.

Para a ciência contemporânea e em especial para a Educação Ambiental, a contribuição da perspectiva sócio-histórica reside na compreensão dos fenômenos

\footnotetext{
${ }^{39}$ Para Chizzotti (2003) na pesquisa qualitativa, os pesquisados são todas as pessoas que participam da pesquisa, são reconhecidos como sujeitos que elaboram conhecimentos e produzem práticas para intervir nos problemas que identificam.
} 
psicológicos como processos mediados, na formação do sujeito enquanto um "quase-social"40 e da subjetividade enquanto fronteira do psicológico e do cultural (MOLON, 2005).

Concluindo, a pesquisa qualitativa orientada pela abordagem sócio-histórica se constitui em uma instância de aprendizagem e de produção de conhecimento na qual o processo é mais importante do que o produto, em que tanto o pesquisador como os pesquisados se ressignificam e aprendem com o desenrolar do próprio trabalho.

\section{INSTRUMENTOS DE PESQUISA}

$\mathrm{Na}$ pesquisa qualitativa, entendemos o trabalho de campo como um recorte espacial que corresponde à abrangência, em termos empíricos, do recorte teórico correspondente ao objeto da investigação. Nesse sentido, o trabalho de campo se constitui numa etapa essencial da pesquisa, que a rigor não poderia ser pensada sem ele (MINAYO, 1996).

A pesquisa qualitativa privilegia algumas técnicas, mas pressupõe que a utilização dessas não deve constituir em um modelo único, exclusivo e estandartizado, uma vez que a pesquisa é uma criação que mobiliza a acuidade inventiva do pesquisador, sua habilidade artesanal e sua perspicácia para elaborar a metodologia adequada. Com base nisso, selecionamos questionários, entrevistas, observação participante e intervenção (oficina) para nos auxiliar nesse processo.

1- Questionários: A utilização desta técnica não é a mais indicada para uma pesquisa de caráter qualitativo como a que estamos desenvolvendo, mas esta não descarta a coleta de dados quantitativos, principalmente na etapa exploratória ou nas etapas em que estes dados podem mostrar uma relação mais extensa entre os fenômenos particulares. Assim, ela tem um caráter complementar ou de um diagnóstico para a seleção dos fatos segundo alguns critérios.

Com base nessas idéias, utilizamos um questionário com perguntas fechadas e abertas (ANEXO A) na primeira Oficina ${ }^{41}$ que desenvolvemos no dia 06/11/2006, com o objetivo principal de buscarmos algumas respostas para os questionamentos levantados na introdução com relação ao nosso problema de pesquisa. Tais informações serviram de base para uma reestruturação das Oficinas.

\footnotetext{
${ }^{40}$ Vigotski defende a idéia de um sujeito “quase-social”, pois é na relação com os outros e por ela, é na linguagem e por ela que se constitui sujeito e é constituinte de outros sujeitos.

${ }^{41}$ Oficina desenvolvida com as professoras de Ensino Fundamental I da Diretoria de Ensino Centro Sul como parte empírica da pesquisa e que será apresentada posteriormente na técnica da intervenção.
} 
2- Entrevistas: Ao lado da observação participante, a entrevista no sentido amplo é a tomada de comunicação verbal e no sentido restrito é a coleta de informações sobre determinado tema científico, ou seja, é a técnica mais utilizada no processo de trabalho de campo.

Como nosso processo de pesquisa é iluminado pela perspectiva sócio-histórica, a entrevista é aqui para nós, marcada por uma dimensão social, uma vez que não se reduz a uma troca de perguntas previamente preparadas, mas é concebida como uma produção de linguagem e, portanto, dialógica em direção ao objetivo estabelecido, que pode vir a ser modificado se as entrevistas demonstrarem outros direcionamentos.

Fizemos a opção pelas entrevistas semi-estruturadas com perguntas abertas e fechadas, onde durante o processo de pesquisa tivemos a possibilidade de discorrermos sobre o tema proposto, sem condições prefixadas. O diálogo aconteceu de forma bastante tranqüila, o que acabou deixando o entrevistado bastante livre para se expressar e expor suas idéias.

A primeira entrevista realizada foi com o Assistente de Trabalho Pedagógico (ATP) de Ciências e Biologia (ANEXO B) uma vez que a ATP do Ensino Fundamental I não demonstrou muito interesse, estando mais preocupada apenas com os trabalhos relacionados com a alfabetização. O objetivo principal desta entrevista foi o de compreender como a Oficina Pedagógica trabalha com a Educação Ambiental em suas escolas e como ela é orientada, em especial no Ensino Fundamental I. O resultado desta entrevista nos possibilitou a escrita de um histórico da Educação Ambiental que é desenvolvida na Diretoria de Ensino Centro Sul e que fará parte deste capítulo.

As demais entrevistas foram realizadas com as professoras. Durante as oficinas, tivemos a oportunidade de entrevistar quatro professoras, sendo cada uma pertencente a um grupo, e com o objetivo principal de compreender melhor o processo de elaboração, desenvolvimento e avaliação das práticas de Educação Ambiental. Após o término das oficinas, e agora com o objetivo de verificar suas contribuições e os avanços do grupo, realizamos novamente mais uma entrevista com as mesmas quatro professoras, totalizando assim oito entrevistas durante esse processo.

3- Observação participante: Esta técnica também é considerada como parte essencial do trabalho de campo em uma pesquisa qualitativa. A observação participante se realiza através do contato direto do pesquisador com o fenômeno observado para obter informações sobre a realidade dos sujeitos sociais em seus próprios contextos. Segundo Minayo (1996a) essa técnica permite captar uma variedade de situações ou fenômenos que não são obtidos por 
meio de perguntas, uma vez que, observados diretamente, transmitem o que há de mais imponderável e evasivo na vida real.

Em um trabalho qualitativo, a observação participante permite que o investigador combine o afazer de confirmar ou infirmar hipóteses com as vantagens de uma abordagem não-estruturada, colocando interrogações que vão sendo discutidas durante o processo de trabalho de campo, eliminando questões irrelevantes e dando ênfase a determinados aspectos que surgem empiricamente.

Nessa pesquisa, os dados sistematizados da observação participante foram extraídos durante o contato com o ATP de Ciências e Biologia, na preparação das Oficinas e durante o desenvolvimento das Oficinas com as professoras. Essas informações foram registradas em um diário de campo no qual além dessas, registramos as nossas percepções, questionamentos, angústias e alegrias.

4- Intervenção: A intervenção nesta pesquisa ocorreu durante a realização das Oficinas de Educação Ambiental elaboradas pelo pesquisador (ANEXO C) e aprovada pela Oficina Pedagógica da Diretoria de Ensino Centro Sul. A Oficina foi a maneira encontrada pelo pesquisador de se aproximar do maior número de escolas de Ensino Fundamental I e, consequentemente, do maior número de professores.

Todas as 41 escolas de Ensino Fundamental I da Diretoria de Ensino Centro Sul foram convidadas para essas Oficinas. Destas, compareceram para a realização do primeiro encontro ainda no segundo semestre de 2006, 30 professoras, provenientes de escolas distintas. Para a realização do segundo encontro, com o objetivo de mantermos o mesmo grupo de trabalho, foram convocadas apenas as professoras que haviam participado do primeiro. Do grupo inicial de 30 professoras, compareceram no segundo encontro 21 professoras de 19 escolas distintas, pois 3 professoras que fazem parte do grupo, se encontram hoje numa mesma escola. $\mathrm{O}$ motivo da redução do número de participantes deu-se basicamente pelo fato de muitas terem perdido suas aulas na última chamada do concurso para Professor de Educação Básica I, ocorrido no final de 2006. Sem vínculo com alguma escola, estas professoras não foram encontradas para participar das Oficinas.

Dos quatro instrumentos de pesquisa selecionados, este foi sem dúvida o mais significativo à medida que estreitou nosso vínculo com as professoras do universo pesquisado. A proposta de trabalho foi muito bem aceita pelo grupo que demonstrou grande interesse e participação. 
Inicialmente, nosso objetivo principal com o desenvolvimento desta Oficina era o de verificar quais as bases teóricas e as concepções que sustentam as práticas de Educação Ambiental assim como analisar a elaboração, o desenvolvimento e a avaliação dessas práticas, mas percebemos logo de início, que também estávamos trabalhando com a formação de professores, uma vez que pelo processo dialético contribuímos conceitual e metodologicamente com o trabalho pedagógico dessas professoras.

Durante a realização da primeira Oficina, além de trabalharmos com o questionário já descrito, trabalhamos com fragmentos de vários textos na tentativa de despertar no grupo uma discussão sobre temas como o processo de ensino e de aprendizagem, conceitos variados de Educação Ambiental, o papel do professor perante essas práticas, a fragmentação do conhecimento, o currículo escolar como um projeto político pedagógico e questões relacionadas com o diálogo e a reflexão.

Na segunda Oficina, realizamos um trabalho de análise sobre os objetivos propostos para o trabalho com o tema Meio Ambiente desenvolvido no PCN Meio Ambiente e Saúde, uma atividade (ANEXO D) sobre as concepções de Educação Ambiental que orientam as práticas desenvolvidas hoje pelas professoras e iniciamos também a discussão do texto "O Cinismo da Reciclagem: o significado ideológico da reciclagem da lata de alumínio e suas implicações para a Educação Ambiental ${ }^{42 \%}$, pois apesar da boa vontade de todas as professoras, ainda percebemos no grupo uma certa ingenuidade sobre algumas questões relacionadas com a Educação Ambiental, fortemente apoiadas por um discurso dominante consumista. Para o estudo deste texto, o mesmo foi dividido em quatro partes, ficando uma parte para cada oficina.

Para a terceira Oficina, além da continuidade da leitura e discussão sobre o texto do "cinismo da reciclarem", concluímos a atividade sobre as concepções de Educação Ambiental, apresentando apenas as correntes mais votadas na oficina anterior e orientando para que as professoras agora apontassem apenas uma, com o objetivo de identificar a corrente que representava aquele grupo. Em seguida, dividimos as professoras em grupo e propusemos que elas elaborassem atividades ou projetos de Educação Ambiental que pudessem ser colocados em prática em suas aulas no período máximo de um mês. Cada grupo teve a liberdade de definir seus temas, objetivos, estratégias e forma de avaliação.

\footnotetext{
${ }^{42}$ LAYRARGUES, Philippe Pomier. O cinismo da reciclagem: o significado ideológico da reciclagem da lata de alumínio e suas implicações para a educação ambiental. In: LOUREIRO, C. F. B., LAYRARGUES, P.P., CASTRO, R.S. (orgs.). Sociedade e meio ambiente: a educação ambiental em debate. $2^{a}$ ed. São Paulo: Cortez, 2002.
} 
Na quarta Oficina, fizemos uma reflexão sobre os conteúdos propostos pelo PCN para o trabalho com o tema Meio Ambiente. Para tanto realizamos uma atividade (ANEXO E), com o objetivo de verificar a compreensão que as professoras tinham sobre cada conteúdo indicado, bem como condições de viabilizar seu desenvolvimento em atividades práticas. Em seguida continuamos com o estudo do texto sobre reciclagem.

Neste dia, não conseguimos realizar a discussão sobre o desenvolvimento dos projetos elaborados e por isso, conseguimos mais uma Oficina complementar para trabalharmos o que ainda faltava, sem ter que correr ou deixar algo que já havíamos proposto realizar.

A quinta Oficina foi marcada pelas discussões dos projetos elaborados na terceira Oficina. Cada grupo teve um tempo inicial para falar sobre o desenvolvimento das atividades, como elas aconteceram, a participação dos alunos, o registro das atividades, as eventuais dificuldades e a avaliação. Após a apresentação de cada grupo, foi feita uma análise do trabalho desenvolvido com o projeto que elas haviam redigido e me entregue no dia da elaboração. Em seguida, abríamos um espaço para todo o grupo falar, podendo dar sugestões de novas atividades ou indicando possíveis alterações. De todos os importantes momentos de nossas oficinas, esse foi sem dúvida alguma um momento bastante rico, pois nos proporcionou uma grande aproximação das concepções das professoras ao elaborarem suas práticas, das principais estratégias que elas utilizam, das relações desses projetos com o currículo oficial, a percepção da escola, às vezes ajudando e outras dificultando a realização dessas práticas, e das maneiras de avaliar esses projetos. Ainda neste dia, terminamos a leitura do texto sobre o "cinismo da reciclagem" e avaliamos suas principais contribuições.

$\mathrm{Na}$ sexta oficina, discutimos um texto que fala sobre projetos ${ }^{43}$, com o objetivo de mostrar para as professoras a abrangência e a complexidade deste tema. Também fizemos uma leitura sobre a Avaliação no tema Meio Ambiente, proposta pelo PCN Meio Ambiente e Saúde e concluímos com uma avaliação geral destes seis encontros e das contribuições para o grupo desta oficina. Por fim, realizamos uma festa de confraternização.

Todos os registros, observações, relatos e depoimentos coletados durante esses seis encontros, nos possibilitaram a construção do capítulo III desta dissertação, com uma análise mais segura e consciente sobre as práticas de Educação Ambiental desenvolvidas pelas professoras do Ensino Fundamental I da Diretoria de Ensino Centro Sul.

\footnotetext{
${ }^{43}$ MACHADO, Nilson José. Sobre a idéia de projeto. Ensaios transversais: cidadania e educação. São Paulo: Escrituras Editora, 1997.
} 


\section{A EDUCAÇÃO AMBIENTAL NA DIRETORIA DE ENSINO CENTRO SUL}

As transformações diárias pelas quais não só o Brasil, mas o planeta vem passando, questionando os hábitos de consumo, poluição e degradação, fazem com que surjam novos elementos e novas maneiras de se conceber o trabalho com a Educação Ambiental. Dessa forma, a Diretoria de Ensino Centro Sul, especificamente, através da Oficina Pedagógica, vem mudando sua concepção e forma de desenvolver o trabalho com a Educação Ambiental, propondo uma nova percepção para esse conceito.

De acordo com o ATP de Ciências e Biologia, "cabe à Oficina Pedagógica e às escolas estarem atentas a essas mudanças, a fim de que se possa gerar um novo e atualizado conceito referente à Educação Ambiental". As escolas na sua quase totalidade desenvolvem trabalhos de Educação Ambiental, nas mais variadas formas e dentro de todos os níveis de ensino. Contudo, percebe-se que mudanças mais significativas ainda são bastante pontuais, o que gera a necessidade de se aprofundar as reflexões, de modo que o trabalho se torne mais consciente.

Atualmente, os projetos de Educação Ambiental ficam a cargo do ATP de Ciências e Biologia, tendo este a colaboração da ATP de Geografia, quando eles conseguem um espaço para o diálogo. Contudo, segundo o ATP de Ciências e Biologia, percebe-se uma mudança significativa na percepção dos demais ATPs, pois há alguns anos atrás, a Educação Ambiental era tida como uma atribuição única e exclusiva da área de Ciências e Biologia e hoje as demais áreas já começam e conseguem perceber a Educação Ambiental como uma área de conhecimento interdisciplinar. Para ele, isso representa um grande avanço da Oficina Pedagógica, momentos em que as diferentes áreas mostram-se dispostas a contribuir e somar esforços.

Quanto à concepção das atividades e projetos de Educação Ambiental na Diretoria de Ensino Centro Sul, alguns são elaborados pela própria Oficina Pedagógica, mas ainda na sua maioria, eles são recebidos da Secretaria Estadual de Educação (SEE). Dessa forma, cabe à Oficina Pedagógica a responsabilidade de repassar e orientar as escolas e os professores para o desenvolvimento destes projetos.

A partir da constatação de que a Educação Ambiental é necessária e obrigatória em todos os níveis de ensino ${ }^{44}$ e que ela pode e deve ser desenvolvida com a colaboração de todas as áreas do conhecimento, segundo o ATP de Ciências e Biologia, as atividades e os projetos de Educação Ambiental são cuidadosamente analisados pela Oficina Pedagógica, para que

\footnotetext{
${ }^{44}$ Artigo 225 do capítulo VI da Constituição Federal de 1988.
} 
eles possam ter um caráter regional na abrangência da Diretoria, onde as adaptações são necessárias para que, tanto os professores como os alunos percebam e compreendam a sua realidade local em consonância com a global.

Devido ao excesso de atribuições da Oficina Pedagógica, percebemos que os ATPs, não têm tempo suficiente para discutir e propor coletivamente projetos de educação ambiental. Sendo assim, essa análise e adaptação dos projetos encaminhados pela SEE, acaba sendo bastante importante e significativa. Quando os projetos são apresentados aos professores, destacam-se os conceitos fundamentais que devem ser abordados e desenvolvidos, deixando livre para que mais adaptações sejam feitas sempre que necessárias à realidade discente local.

Quanto ao envolvimento das escolas nos projetos, todas apresentam algum tipo de trabalho, mesmo que ainda não seja o ideal, segundo o ATP. Com relação às capacitações oferecidas, a participação é boa, mas, ainda pode melhorar, pois dificilmente se consegue trabalhar com todas as escolas em um mesmo encontro. Isso acontece por uma série de fatores: um deles é por problemas de comunicação - as escolas são comunicadas por e-mails, mas estas nem sempre repassam as informações aos professores. Outro, principalmente relacionado com os professores de Ensino fundamental I, pelo fato de a escola nem sempre ter professor substituto para ficar com a classe no dia da capacitação. Isso é motivo de discussão e preocupação da Oficina e em especial da Dirigente de Ensino em propor novas estratégias que garantam momentos coletivos com os envolvidos no processo.

Com relação à avaliação dos trabalhos e projetos, esta ainda precisa ser mais discutida e refletida. As avaliações vêm ocorrendo, mas para o ATP, não como deveriam. Para ele, "nem sempre se consegue captar tudo o que é produzido nas escolas com maior precisão. Tem-se uma visão do todo, sabe-se do desenvolvimento e resultado dos trabalhos, mas às vezes, o processo fica prejudicado". A sobrecarga de atividades tem prejudicado bastante esse processo de avaliação. Segundo o ATP, “avaliar acaba por mostrar novos caminhos, possibilita rever posições e propor novas tomadas de decisões, o que em Educação Ambiental é fundamental em razão do seu caráter dinâmico e transversal".

No Ensino Fundamental, tanto no ciclo I como no ciclo II, as práticas de Educação Ambiental já fazem parte de todos os currículos. Todas as séries têm contemplado no seu planejamento um trabalho voltado para a Educação Ambiental. Percebe-se uma preocupação bastante grande dos professores em participar de capacitações e cursos oferecidos pela Diretoria e pela própria SEE. Para o ATP, talvez o Ensino Fundamental I seja um dos níveis no qual mais incisivamente se trabalhe com a Educação Ambiental, o que deve ser natural em 
razão do potencial de clientela que se atende nesse nível, além da excepcional fase de vida que esses alunos se encontram diante do processo de formação humana. Apesar de se ter na Diretoria de Ensino uma ATP de Ensino Fundamental I, as atividades de Educação Ambiental neste nível de ensino são desenvolvidas como já falamos anteriormente pelo ATP de Ciências e Biologia, com o auxílio das demais áreas.

Para o ATP de Ciências e Biologia, há uma urgência na qualificação dos trabalhos em Educação Ambiental. Para isso, segundo ele, o caminho é trazer para o foco das discussões os assuntos relacionados com a Educação Ambiental para que se possa subsidiar o trabalho dos professores em sala de aula e criar uma rede mais integrada, onde as boas idéias possam ser divulgadas e socializadas, ou seja, deve-se criar uma identidade dos trabalhos desenvolvidos na Diretoria, como uma prática diária, crítica e consciente por parte de todos os envolvidos. 


\section{CAPÍTULO III}

\section{ATIVIDADES DE EDUCAÇÃO AMBIENTAL NO ENSINO FUNDAMENTAL I: UMA EXPERIÊNCIA.}

"A alegria é o que sentimos quando percebemos o aumento da nossa
realidade, isto é, de nossa força interna e capacidade para agir.
Aumento de pensamento e de ação, a alegria é o caminho da
autonomia individual e política...".
Marilena Chaú.

O SURGIMENTO DAS ATIVIDADES DE EDUCAÇÃO AMBIENTAL

Para falarmos do surgimento das Atividades de Educação Ambiental no Ensino Fundamental I, e aqui em específico na Diretoria de Ensino Centro Sul, começaremos apontando suas possíveis origens: 1) do interesse ou da necessidade do próprio professor; 2) do interesse ou da necessidade da escola; 3) da elaboração e encaminhamento pela Oficina Pedagógica; 4) da elaboração e encaminhamento pela Secretaria da Educação do Estado de São Paulo.

Quanto à abrangência destas atividades, elas podem se resumir a uma sala de aula e a um grupo de alunos, no caso específico do interesse ou da necessidade de um professor ou abranger o Estado todo, quando se tratar de uma atividade ou projeto da Secretaria de Educação. Nesse caso, cada Diretoria de Ensino que compõe o Estado de São Paulo por meio da sua Oficina Pedagógica assume a coordenação do projeto.

Neste estudo, daremos destaque às atividades e aos projetos de Educação Ambiental propostas pelos próprios professores individualmente e os propostos pela escola, nesse caso, sempre na forma de um projeto, abrangendo alunos e professores.

No início do ano letivo já são previstos no planejamento, da grande maioria das professoras, as atividades e os projetos de Educação Ambiental que deverão ser trabalhados e desenvolvidos durante $o$ ano. Outras disseram que as atividades vão surgindo espontaneamente durante o desenvolvimento dos conteúdos, principalmente os relacionados com as disciplinas de Ciências e Geografia. 
Como estamos discutindo o surgimento das atividades de Educação Ambiental, acreditamos ser importante refletir um pouco sobre as principais correntes ${ }^{45}$ de Educação Ambiental. Quais são e como podem influenciar nas atividades e nos projetos.

Segundo Sauvé (2005) apesar da preocupação comum do campo da Educação Ambiental com o meio ambiente e do reconhecimento do papel central da educação para a melhoria deste, adotam-se diferentes discursos sobre Educação Ambiental e propõem-se diversas maneiras de conceber e praticar a ação educativa neste campo, fazendo assim com que surjam as diferentes correntes. Analisaremos as principais correntes em dois grupos: um que tem longa tradição, dominantes entre as décadas de 70 e 80 e outro mais recente, que abrange preocupações mais atuais. Nosso objetivo aqui não é o de nos aprofundarmos em cada uma das correntes, mas apenas darmos uma visão geral de qual é a concepção dominante de meio ambiente e qual sua intenção central com a Educação Ambiental. Assim, segundo Sauvé (2005):

\section{Correntes de longa tradição}

\begin{tabular}{|l|l|l|}
\hline \multicolumn{1}{|c|}{ Correntes } & \multicolumn{1}{|c|}{$\begin{array}{c}\text { Concepção do meio } \\
\text { ambiente }\end{array}$} & \multicolumn{1}{|c|}{ Enfoque dominante } \\
\hline Corrente Naturalista & Natureza & $\begin{array}{l}\text { Sensorial, Afetivo, } \\
\text { Experiencial, Cognitivo, } \\
\text { Criativo/Estético }\end{array}$ \\
\hline $\begin{array}{l}\text { Corrente } \\
\text { Conservacionista/Recursista }\end{array}$ & Recurso & Cognitivo, Pragmático \\
\hline Corrente Resolutiva & Problema & Cognitivo, Pragmático \\
\hline Corrente Sistêmica & Sistema & Cognitivo \\
\hline Corrente Científica & Objeto de estudos & Cognitivo, Experimental \\
\hline Corrente Humanista & Meio de Vida & $\begin{array}{l}\text { Sensorial, Afetivo, } \\
\text { Experimental, Cognitivo, } \\
\text { Criativo/Estético }\end{array}$ \\
\hline Corrente Moral/Ética & Objeto de valores & Cognitivo, Afetivo, Moral \\
\hline
\end{tabular}

\footnotetext{
${ }^{45}$ A noção de "corrente" refere-se aqui a maneira geral de conceber e de praticar a Educação Ambiental.
} 


\section{Correntes recentes}

\begin{tabular}{|c|c|c|}
\hline Correntes & $\begin{array}{c}\text { Concepção do meio } \\
\text { ambiente }\end{array}$ & Enfoque dominante \\
\hline Corrente Holística & Total, Todo, O Ser & $\begin{array}{l}\text { Holístico, Orgânico, Intuitivo, } \\
\text { Criativo }\end{array}$ \\
\hline Corrente Biorregionalista & $\begin{array}{l}\text { Lugar de pertença } \\
\text { Projeto Comunitário }\end{array}$ & $\begin{array}{l}\text { Cognitivo, Afetivo, } \\
\text { Experiencial, Pragmático, } \\
\text { Criativo }\end{array}$ \\
\hline Corrente Práxica & Cadinho de ação/reflexão & Práxico \\
\hline Corrente Crítica & $\begin{array}{l}\text { Objeto de transformação } \\
\text { Lugar de emancipação }\end{array}$ & $\begin{array}{l}\text { Práxico, Reflexivo, } \\
\text { Dialogístico }\end{array}$ \\
\hline Corrente Feminista & Objeto de Solicitude & $\begin{array}{l}\text { Intuitivo, Afetivo, Simbólico, } \\
\text { Espiritual, Criativo/Estético }\end{array}$ \\
\hline Corrente Etnográfica & $\begin{array}{l}\text { Território, Lugar de } \\
\text { identidade, Natureza/cultura }\end{array}$ & $\begin{array}{l}\text { Experiencial, Intuitivo, } \\
\text { Afetivo, Simbólico, Espiritual, } \\
\text { Criativo/Estético }\end{array}$ \\
\hline Corrente da Ecoeducação & $\begin{array}{l}\text { Pólo de interação para a } \\
\text { formação pessoal } \\
\text { Cadinho de identidade }\end{array}$ & $\begin{array}{l}\text { Experiencial, Sensorial, } \\
\text { Intuitivo, Afetivo, Simbólico } \\
\text { Criativo }\end{array}$ \\
\hline $\begin{array}{l}\text { Corrente de } \\
\text { Desenvolvimento } \\
\text { Sustentável }\end{array}$ & $\begin{array}{l}\text { Recursos para o } \\
\text { desenvolvimento econômico } \\
\text { Recursos compartilhados }\end{array}$ & Pragmático, Cognitivo \\
\hline
\end{tabular}

Embora cada uma das correntes apresentadas tenha um conjunto de características específicas, o que faz com que elas se diferenciem umas das outras, elas não são totalmente excludentes em todos os aspectos, uma vez que compartilham características comuns.

Como já mencionamos anteriormente, nossa maneira de conceber e de praticar Educação Ambiental coincide com as correntes práxica e crítica, onde a Educação de maneira geral se desenvolve em uma perspectiva participativa e emancipatória, que privilegia a crítica, a reflexão, a solidariedade e a transformação das realidades.

De acordo com Sauvé (2005,p.29, grifos do autor), a ênfase da corrente práxica "está na aprendizagem na ação, pela ação e para a melhoria desta”, onde a práxis consiste 
essencialmente em integrar a reflexão e a ação que se alimentam mutuamente. Seu processo é por excelência o da pesquisa-ação cujo objetivo essencial é o de operar uma mudança no meio ambiente e nas pessoas, envolvendo os diferentes sujeitos de uma situação por transformar numa dinâmica participativa.

Um modelo pedagógico que muito bem ilustra a corrente práxica é o da pesquisa-ação para a resolução de problemas comunitários proposto por Stapp (1988, apud Sauvé, 2005$, p.30 $)^{46}$, ou seja, resolver um problema socioambiental percebido no meio imediato da vida, integrando uma reflexão constante sobre o projeto de ação empreendido: "por que empreendemos esse projeto? Nossa finalidade e nossos objetivos mudam no caminho? Nossas estratégias são apropriadas? O que aprendemos durante a realização do projeto? $O$ que ainda devemos aprender? Nossa dinâmica de trabalho é saudável?” Projeto este que se constitui como um cadinho de aprendizagem, uma vez que não se trata de saber tudo antes de passar para a ação, mas de aceitar aprender na ação e ir reajustando e transformando, sobretudo nossas maneiras tradicionais de ensinar e aprender.

Muitas vezes associada à corrente práxica, a corrente crítica insiste na análise das dinâmicas sociais que se encontram na base das realidades e problemáticas ambientais com uma postura crítica - numa perspectiva de emancipação, de libertação das alienações - e com um componente necessariamente político que aponta para a transformação das realidades. Nessa perspectiva, cada aluno é convidado a refletir sobre o projeto, sua essência, para assim aclarar sua razão de ser, seu significado e para descobrir o que aprende ao realizar tal ação.

Ao demonstrar o cenário das principais correntes e aprofundada nossa justificativa pelo engajamento nas correntes práxica e crítica, partiremos para a análise de uma atividade (anexo D) realizada com as professoras durante uma das oficinas.

O objetivo desta atividade era o de compreender como as professoras concebem e praticam a Educação Ambiental nas suas práticas diárias. Sem dividir as correntes entre as de mais longa tradição e as mais recentes e sem nomeá-las, o que poderia influenciar a escolha, fizemos uma leitura e discussão dos principais pontos de cada uma. Em seguida, cada professora teve que indicar duas correntes que mais se aproximavam da sua concepção e daquilo que elas buscavam com suas atividades de Educação Ambiental.

Na primeira fase da atividade, das 15 correntes apresentadas, as mais votadas foram a Conservacionista/Recursista, a Resolutiva, a Científica e a Moral/Ética das de longa tradição e a Práxica, Etnográfica e da Ecoeducação pertencendo às correntes mais recentes. Em um

\footnotetext{
${ }^{46}$ STAPP, W.;BULL, J.;COLL. Education in action - A Community Problem Solving Programs for schools. Dexter ( Michigan): Thompson Shore, Inc.,1988.
} 
próximo encontro, com a mesma finalidade inicial e ainda sem os nomes específicos de cada corrente, as professoras tiveram que apontar uma dentre as sete correntes mais votadas na primeira atividade. Nesta etapa, as duas mais votadas foram a Conservacionista/Recursista e a Científica. A corrente práxica foi apontada por apenas uma professora.

A corrente Conservacionista/Recursista agrupa proposições centradas na conservação dos recursos, tanto no que concerne à qualidade quanto à disponibilidade. Nesta corrente, quando se fala em "conservação da natureza", como da biodiversidade, trata-se sobretudo de uma natureza-recurso. Os programas de Educação Ambiental centrados nos três "R" e aqueles com preocupações de gestão ambiental se associam a esta corrente. Assim, os objetivos da Educação Ambiental são os de adotar comportamentos de conservação e desenvolver habilidades relativas à gestão ambiental. Já na corrente Científica, as proposições de Educação Ambiental dão ênfase ao processo científico, com o objetivo de abordar com rigor as realidades e problemáticas ambientais, e de compreendê-las melhor. O enfoque nesta corrente é sobretudo cognitivo, onde o meio ambiente é objeto de conhecimento para escolher uma solução ou ação apropriada. Dessa forma, a concepção de meio ambiente é tida como objeto de estudo.

Compreendido um pouco sobre o modo de conceber e praticar a Educação Ambiental pelo grupo, partimos para outro momento bastante rico das oficinas com a elaboração de atividades e projetos de Educação Ambiental. Novamente divididas em grupos, foi pedido para que as professoras elaborassem atividades ou pequenos projetos que pudessem ser colocados em prática para que os resultados pudessem ser discutidos em um próximo encontro. O tema era livre pois poderia coincidir com o conteúdo que estivesse sendo desenvolvido nas aulas. Nosso objetivo foi o de observar como as professoras organizavam suas atividades e quais as práticas mais utilizadas por elas, uma vez que já tínhamos uma visão geral de como o grupo concebia a Educação Ambiental. No total, tivemos a elaboração de seis projetos que foram colocados em prática. Não iremos aqui especificar nenhum deles, mas sim tentar analisá-los como um todo, buscando definir características comuns no grupo.

Inicialmente percebemos uma dificuldade geral nas professoras em sistematizar as idéias do projeto a ser desenvolvido e em passá-las para o papel. A professora da UE 05 disse:

"é muito difícil escrever tudo como estamos pensando, a gente não pode só explicar o que quer fazer? Na escola como a gente já sabe de cabeça como fazer as atividades, já estamos acostumadas, as atividades são surgindo naturalmente e a gente vai fazendo". 
Os projetos na sua grande totalidade apresentavam um título que, na maioria das vezes, se referia ao tema a ser trabalhado, e já traziam os objetivos, quase sempre misturados e confundidos com as estratégias. Quanto aos temas abordados, eles se resumiram à questão do lixo, poluição, economia de água, luz e reutilização de materiais através da reciclagem.

De forma geral, as estratégias comuns para iniciar os projetos foram uma conversa informal, chamada pelas professoras de a "hora do bate papo", ou textos informativos ou ainda através de pesquisa. Após esses momentos de "discussão", geralmente era proposto um registro e as atividades mais utilizadas para isso foram a reescrita de texto ou a elaboração de um texto coletivo, a confecção de cartazes e propagandas, o trabalho com recorte e colagem. Também propuseram uma atividade de reciclagem - uma "estrela" nos projetos de Educação Ambiental. Quanto a avaliação, dois projetos não a registraram a não comentaram nada sobre como ela seria e os outros quatro avaliavam todo o processo com a simples análise do material produzido e confeccionado pelos alunos ou com uma exposição deste material.

Através desta breve análise, conseguimos observar que o grupo apresenta uma grande dificuldade em definir e elaborar seus projetos. Inicialmente, não demonstraram nenhuma preocupação com uma justificativa, ou seja, "o porquê" desenvolver um projeto. Em seguida, com relação aos objetivos, o seja, "o quê" elas queriam com o projeto, muitas vezes estes se confundiam com as estratégias, não deixando claro o que realmente queriam. Na descrição das estratégias ou do "como" fazer, estas na sua maioria, não se relacionavam com os objetivos estabelecidos. Parecia mais uma relação de atividades a compor um projeto maior, ou ainda várias atividades para se aplicar. Por fim, quando descrita e realizada, as avaliações se resumiam em verificar o cumprimento das atividades propostas e a exposição dos materiais confeccionados pelos alunos durante a realização dos projetos. A avaliação não era tida como um processo de reflexão sobre todo o caminho percorrido. Reflexão esta, importante tanto para professores quantos para os alunos, verificando se os objetivos foram atingidos, se houve dificuldades no desenvolvimento, se existe a necessidade de alguma reformulação ou atividade complementar. Não estamos aqui querendo definir uma padrão para se registrar um projeto, mas acreditamos que se algumas perguntas não forem respondidas inicialmente, se não deixarmos claro o "porquê", "o quê" e o "como" trabalhar e avaliar, as idéias vão se perdendo ou sendo esquecidas durante o processo, o que certamente comprometerá qualquer projeto por mais bem intencionado que ele possa ser.

Também conseguimos identificar como a concepção de Educação Ambiental que as professoras têm se refletem em suas práticas. As preocupações com o desperdício, com a preservação e a conservação dos recursos naturais, com a questão do lixo, da poluição, e da 
reciclagem, da forma como foram abordadas e trabalhadas destinam-se apenas a levar os alunos a uma mudança de comportamento, o que muito se aproxima da corrente conservacionista/recursista. O trabalho com textos informativos, com pesquisas que não levam a grandes discussões e reflexões, demonstram uma forte relação com a corrente Científica cujo enfoque é sobretudo cognitivo. Não estamos aqui negando a importância do trabalho com os textos informativos, muito menos com o enfoque cognitivo. Nossa crítica se deve ao fato de as atividades terem se resumido a isso, não demonstrando posteriormente nenhuma preocupação com a reflexão, a crítica e a mudança de valores.

Acreditamos que faltam informações e argumentos para esses professores discutirem realmente projetos e atividades de Educação Ambiental que levem a uma mudança de valores, principalmente nos padrões de consumo capitalista. Infelizmente essa falta de informações e argumentos acaba fazendo com que os professores sejam apenas reprodutores de um discurso ecológico oficial ${ }^{47}$, o que pode ser claramente observado com a distorção da Pedagogia dos 3Rs para a "Pedagogia da Reciclagem". Inverte-se o primeiro R de "reduzir", pelo R de "reciclar" camuflando assim a crítica ao capitalismo e ao consumismo. Privilegia-se a reciclagem uma vez que esta não questiona o consumismo e mantém os altos padrões de consumo.

Muitas vezes, a falta de domínio em alguns conteúdos e até mesmo de argumentos pode acabar gerando uma insegurança nos professores que pode se refletir numa falta de interesse em participar de projetos que envolvam pessoas de diferentes áreas do conhecimento.

Com isso pudemos observar que apesar de uma vontade genuína por parte das professoras em desenvolver uma Educação Ambiental crítica e reflexiva, não só o grupo pesquisado, mas os professores de modo geral acabam sendo vítimas de um discurso dominante e de uma visão reducionista de Educação Ambiental preocupada apenas com a mudança de comportamentos e não com a mudança de valores. Salvo algumas atividades e alguns projetos pontuais preocupados com as questões econômicas, políticas, sociais e culturais, ainda predomina uma visão muitas vezes conservacionista organizada em torno da preocupação de simplesmente preservar os recursos naturais, protegendo fauna e flora, com uma concepção de ambiente que muitas vezes para a maioria das pessoas está restrita aos bichos, às plantas e ao lixo; visão esta ainda muitas vezes reforçada pelos livros didáticos.

\footnotetext{
${ }^{47}$ Segundo Carvalho (1991) é o discurso enunciado pelo ambientalismo governamental, representante da ideologia hegemônica e encarregado de manter os valores culturais instituídos na sociedade.
} 
Não queremos entrar no terreno da crítica negativa, afinal os professores enfrentam uma série de dificuldades de todas as ordens para desenvolver suas atividades, mas não podemos negar o envolvimento "ingênuo" destes com a temática ambiental. Não conseguem discutir as razões explicativas do quadro de degradação ambiental, não percebendo a relação entre os problemas ambientais e o contexto político, social, econômico e cultural existentes.

Das várias dificuldades para a inserção da Educação Ambiental no ensino formal, podemos aqui destacar duas delas: as formas tradicionais de ensino, que dão prioridade a conhecimentos teóricos, abstratos e informativos em detrimento dos problemas concretos e regionais; e a defasagem de atualização dos docentes em relação aos avanços do conhecimento científico.

Prosseguindo nossa caminhada no intuito de compreender as práticas de Educação Ambiental ainda na sua gênese, faremos agora uma análise dos conteúdos propostos pelo PCN.

\section{CONTEÚDOS DE MEIO AMBIENTE PROPOSTOS PELO PCN}

Sabemos hoje, que os PCNs são uma referência curricular nacional a ser discutida e traduzida em propostas regionais e municipais, cujo principal objetivo é provocar uma reflexão acerca da função da escola, sobre o que, quando, como e para quem ensinar, com destaque aos temas sociais urgentes que aparecem organizados nos temas transversais.

Nessa pesquisa, cujo tema central está nas práticas de Educação Ambiental, daremos especial atenção ao tema transversal Meio Ambiente que é sem dúvida alguma, uma importante contribuição para a inserção da Educação Ambiental nas escolas e por ser um dos únicos documentos oficiais de que dispõem os professores para se orientarem quanto às atividades de Educação Ambiental.

Além de alguns problemas e dificuldades já citadas por nós nesta pesquisa sobre a viabilização do trabalho com os temas transversais de modo geral, resta ainda muita dúvida sobre os limites da capacidade das escolas e dos professores compreenderem as propostas contidas nesse documento, bem como motivação suficiente ou metodologia para executá-las. Assim, com o objetivo de compreender melhor a relação deste documento com os currículos escolares, com os próprios professores, sua compreensão e sua tradução nas práticas diárias, 
desenvolvemos uma atividade (ANEXO E) com os conteúdos de Meio Ambiente propostos pelo PCN Meio Ambiente e Saúde.

No dia em que desenvolvemos esta atividade, contávamos com 17 professoras todas pedagogas sem nenhuma outra formação superior. Deste grupo, apenas uma professora já tinha realizado um estudo individual mais aprofundado do PCN Meio Ambiente e Saúde. As demais sabiam da existência do material, mas sem maiores conhecimentos. Algumas só o tinham utilizado para a elaboração do Planejamento Escolar Anual, citando os conteúdos que deveriam ser trabalhados durante o ano letivo.

Quando questionadas sobre suas participações em algum grupo de discussão e reflexão sobre esse material, antes deste momento que estávamos vivenciando, novamente apenas uma professora disse ter participado de um momento coletivo de estudo em sua Graduação, no curso de Pedagogia.

Em seguida, partimos para uma leitura cuidadosa dos conteúdos propostos pelo PCN que se organizam em três blocos: 1) Os ciclos da natureza, 2) Sociedade e Meio Ambiente e 3) Manejo e Conservação Ambiental, a fim de analisarmos a compreensão de cada conteúdo proposto e de como este poderia ser traduzido em atividades práticas. Para tanto, foram estabelecidos três critérios de análise já propostos anteriormente pelo grupo: claro compreende perfeitamente e sabe como desenvolver, pouco claro - conhece, mas não tem muita clareza, e tem dificuldades em desenvolver e, muito confuso - não sabe o que tem de ser trabalhado e desenvolvido.

$\mathrm{Na}$ análise do bloco 01 - Os ciclos da natureza, apenas o item 1, relacionado com água foi tido como claro, ou seja, todas as professoras que participaram da atividade compreendem perfeitamente e sabem como desenvolver o conteúdo. O item 3 foi tido como pouco claro, assim, elas conhecem o assunto mas não têm muita clareza, tendo algumas dificuldades para desenvolvê-lo. Os itens 2, 4 e 5 foram tidos como muito confusos. Na análise geral do grupo para este bloco, os conteúdos precisam ter mais clareza, pois apresentam uma linguagem bastante específica, o que requer um estudo aprofundado.

No bloco 02 - Sociedade e Meio Ambiente, nenhum item foi tido como claro pelo grupo. Os itens 1, 3, 4 e 7 foram apontados como pouco claros, apresentando algumas dúvidas na compreensão e na viabilização das atividades. Apenas o item 2 foi tido como muito confuso, por ser muito abrangente. Ninguém do grupo tinha idéia do que trabalhar neste conteúdo. Também na análise geral deste bloco, o grupo indicou a necessidade de maior clareza e linguagem mais simples e acessível. 
Por fim, na análise do bloco 3 - Manejo e conservação ambiental apenas os itens 8 e 11 foram tidos como claros. Os itens 1, 6 e 9 ficaram entre claros e pouco claros, pois a maioria sabe o quê deve ser trabalhado, mas encontram dificuldades ou têm dúvidas em como trabalhar. Agora os itens 2, 4, 5, 7, 10 e 12 ficaram entre pouco confusos e muito confusos. Para o grupo, os itens do bloco 03 são bastante abrangentes com alguns itens muito específicos, o que dificultou a sua compreensão.

$\mathrm{Na}$ análise geral do grupo, os conteúdos de Meio Ambiente propostos pelo PCN não estão claros da forma como estão apresentados, pois em alguns casos são muito confusos, sendo uns muito específicos e outros muito abrangentes.

Desta análise dos conteúdos, um fato que nos chamou a atenção e que vem confirmar as concepções de Educação Ambiental das professoras pesquisadas, é que os três únicos conteúdos que foram apontados como claros (item 1 do bloco 01 e os itens 8 e 11 do bloco 03) são os relacionados com o uso racional dos recursos naturais e com a reciclagem. Confirmam uma visão reducionista de Educação Ambiental que não estabelece relação entre a problemática ambiental com os fatores políticos, sociais, culturais e econômicos, que muito se aproximam da corrente conservacionista/recursista.

Ainda segundo o grupo, esses conteúdos poderiam estar divididos entre os dois ciclos do ensino fundamental, pois ficaria mais fácil saber o que realmente deveria ser trabalhado e enfatizado no ensino fundamental I ( $1^{\mathrm{a}}$ a $4^{\mathrm{a}}$ séries $)$ e o que ficaria para ser trabalhado e aprofundado no ensino fundamental II ( $5^{\mathrm{a}}$ a $8^{\mathrm{a}}$ séries $)$ :

Prof. (UE07): "Da maneira como os conteúdos estão expostos para serem passados de $1^{\mathrm{a}}$ a $8^{\mathrm{a}}$ séries; (principalmente de $1^{\mathrm{a}}$ a $4^{\mathrm{a}}$ séries), não estão claros ao meu ver e eu teria que pesquisar muito antes de dar os temas, me aprofundar bem".

Prof. (UE14): "Faltou detalhamento nos itens e faltou um direcionamento; apontar a seqüência dos trabalhos (conteúdos) de acordo com as séries pois isso ia facilitar para o professor saber o que o seu aluno já tinha estudado, o que você deveria ensinar naquele ano e o outro professor do ano seguinte também saberia o que ele deveria ensinar e assim na $8^{\text {a }}$ série o aluno teria visto todo o conteúdo de meio ambiente". 
Em vários momentos também podemos observar a questão da falta de clareza dos conteúdos justificada como sendo estes conteúdos muito específicos e assim mais fáceis de serem compreendidos e trabalhados por especialistas como professores de Ciências, Biologia e Geografia, segundo uma professora:

Prof. (UE03): "É difícil você trabalhar com um conteúdo específico de Ciências e Biologia que você não domina. Eu sei um pouco que aprendi na escola quando estudava mas na Pedagogia não estudei essas matérias específicas assim para ensinar. Alguma coisa a gente aprende nos livros, mas não sabe aprofundar e discutir com muita segurança. Acaba ficando superficial”.

concordando, a Professora da UE 07 completa:

... "e os professores de Geografia também têm mais facilidade para trabalhar com esses conteúdos do meio ambiente, entendem melhor e conseguem aprofundar mais. Como a nossa formação é de Pedagogia, precisamos de uma orientação desses especialistas para esses conteúdos mais específicos”.

Segundo Sato (1997) temas ligados à Educação Ambiental parecem intimamente ligados às disciplinas de Ciências e Geografia. A partir disso, podemos observar que os planos e os currículos escolares passaram por uma adequação, principalmente com os objetivos e conteúdos propostos pelos PCNs, mas como verificamos nessa atividade, este documento ainda é uma incógnita nas escolas, pois os professores têm muitas dificuldades em compreendê-lo, traduzi-lo e colocá-lo em prática, reforçando o descompasso entre as intenções explícitas e sua tradução nas práticas da sala de aula e mais ainda, a distância entre a produção dos programas oficiais e a sua influência na escola. O fosso entre o conhecimento e a realidade se evidencia na análise do conteúdo curricular da grade oficial que privilegia conhecimentos genéricos, não relacionados com a realidade na qual estão inseridos professores e alunos. Assim, a possibilidade de a Educação Ambiental alimentar o espírito crítico que é o ponto central de uma educação transformadora fica cada vez mais distante. Nesse sentido, Macedo (1999) observa que os PCNs pouco ajudaram na diferenciação e compreensão entre trabalho com projetos, interdisciplinaridade e temas transversais. 


\section{EDUCAÇÃO AMBIENTAL E OS PROJETOS INTERDISCIPLINARES.}

Como já dissemos anteriormente, a ênfase nas práticas interdisciplinares nas questões ambientais deve-se à constatação de que os problemas que afetam e mantêm a vida no nosso planeta são de natureza global e que a compreensão de suas causas não pode se restringir apenas à dimensão e aos fatores estritamente biológicos, mas também aos políticos, econômicos, sociais e culturais.

Interdisciplinaridade que não se prende à unificação de saberes, mas a um espaço de troca e articulação entre os diferentes conhecimentos e saberes, promovendo a troca de conhecimento e o diálogo dos saberes especializados com os saberes não científicos.

Dessa forma, a Educação Ambiental no contexto das práticas interdisciplinares aponta para a necessidade de elaboração de propostas pedagógicas centradas na conscientização, mudança de atitudes e práticas sociais, desenvolvimento de conhecimento e capacidade de avaliação e participação dos educandos.

Uma vez que a Educação Ambiental é na sua essência interdisciplinar é impossível imaginar sua prática sem associá-la à idéia de interdisciplinaridade. Assim desenvolveremos algumas observações com relação às dificuldades no trabalho com projetos e com a questão da interdisciplinaridade nas atividades de Educação Ambiental. Para tanto, retomaremos os projetos elaborados e desenvolvidos pelas professoras durante as oficinas.

Da análise destes projetos, destacaremos os seguintes pontos: inadequação com o Projeto Político Pedagógico da escola, barreiras institucionais que dificultam a viabilização do trabalho com projetos, falta de espaço e tempo para a discussão, proposição e elaboração de trabalhos coletivos, falta de recursos materiais e financeiros, problemas com a avaliação, falta de continuidade dos projetos e principalmente com a questão da interdisciplinaridade.

Inicialmente, pudemos observar que tanto as atividades como os projetos de Educação Ambiental são considerados como atividades "extras", ou seja, de importância menor dentro de uma grade curricular ampla e obrigatória. Deram-nos a idéia de algo complementar a um conteúdo ou a um objetivo maior a ser alcançado. Nesse sentido, sobre a inadequação dos projetos com o Projeto Político Pedagógico, pesquisas recentes destacam a necessidade da sua reformulação com a execução de um planejamento onde temas como a intedisciplinaridade e o enfoque ambiental não deveriam ser apenas tópicos no meio de tantos outros objetivos, mas se constituíssem como objetivos desse projeto maior. A respeito disso, Reigota (1999) afirma que é muito difícil introduzir a Educação Ambiental nesses parâmetros atuais, uma vez que ela traz muitos desafios à escola e às representações que temos dela. 
Outro ponto refere-se às barreiras institucionais, onde podemos destacar a alta rotatividade de alguns professores e a falta de apoio de alguns coordenadores e diretores. Os professores que não têm o cargo efetivo na unidade escolar têm que escolher suas aulas no início do ano letivo na Diretoria de Ensino e acabam indo para as escolas onde têm aula, ou seja, não necessariamente onde trabalhou no ano letivo anterior. Pior que esse fato, só a mudança de escola ou a perda total das aulas durante o ano letivo, como presenciamos no início das nossas oficinas. No segundo semestre de 2006 houve ingresso de professores de Ensino Fundamental I na Rede Estadual de Educação no Estado de São Paulo e muitas professoras que faziam parte do nosso grupo acabaram perdendo suas aulas. Algumas conseguiram aula em outra escola, mas algumas infelizmente terminaram o ano desempregadas.

As flutuações às quais estão expostos os professores, devido às recentes mudanças na política educacional, comprometem significativamente a implantação de projetos que durem mais de um ano, já que os professores não sabem se permanecerão na mesma escola e com a mesma clientela cada vez que o ano se encerra.

Além dessas mudanças a que estão sujeitos os professores, outro fator que pode dificultar o trabalho com projetos e que pudemos observar na fala de algumas professoras, refere-se à postura da coordenação e da direção da escola. Às vezes, mesmo os professores estando motivados, a direção pode criar barreiras que efetivamente desestimulam todo o trabalho. Tudo o que foge do "padrão sala de aula" não é bem visto em alguns casos pela coordenação e pela direção escolar.

Prof. (UE10): “Já fui chamada a atenção várias vezes por estar fazendo atividades com meus alunos no pátio. Criança sabe como é, tem muita energia, eles se empolgam com algumas atividades, principalmente quando fizemos a separação de material para a reciclagem, parecia uma grande bagunça, mas fazia parte do meu projeto essa separação de materiais”.

Outra professora, pelo contrário, diz que recebe todo o apoio da coordenação e direção.

Prof. (UE09): "Tanto nossa coordenadora como a diretora valorizam muito essas atividades com nossos alunos. Elas nos dão o maior apoio 
quando queremos desenvolver alguma atividade extra, principalmente com passeios".

Dessa forma, podemos observar o quanto a percepção da comunidade escolar direção, coordenação, professores, funcionários em geral, pais e alunos - sobre a importância do trabalho com o meio ambiente pode interferir na realização das atividades de Educação Ambiental. Quanto à percepção dos pais, uma professora relata:

Prof. (UE05): "Um pai foi até a escola querer saber o que tanto nós fazíamos com lixo, pois disse que quase todo o lixo da casa dele agora vinha para a escola e perguntou se esse trabalho com o lixo realmente era importante para o seu filho; se fazer reciclagem agora era coisa de escola também".

Para Bizerril e Faria (2001) o tipo mais curioso de resistência às mudanças no ensino é sem dúvida o advindo da parte dos próprios alunos e seus pais, pois para muitos deles, a escola é vista apenas como transmissora de conteúdos e informações que irão preparar os alunos para etapas subseqüentes da vida, como o vestibular, por exemplo.

Outro ponto que pode interferir no desenvolvimento de projetos, refere-se à falta de tempo e espaço, uma vez que nem todos os professores de uma escola conseguem se reunir para discutir, propor e elaborar projetos coletivos. No Ensino Fundamental I pode-se reunir todos os professores de um período durante o horário de trabalho pedagógico coletivo (HTPC), mas não os da escola toda. No Ensino Fundamental II com a divisão dos professores por disciplinas e com a sobrecarga de atividades e escolas de cada professor, estes horários coletivos se tornam ainda mais complicados. Além dessa dificuldade, observamos que nem sempre esse horário é bem utilizado. Ao invés de se tratarem de assuntos pedagógicos de interesse de todos, com o estudo de orientações, propostas de trabalho, elaboração de projetos coletivos, avaliação de atividades conjuntas, esses horários acabam sendo reduzidos na maioria das escolas para a discussão de problemas geralmente relacionados com a indisciplina dos alunos e o cumprimento de atividades como preenchimento de diário, correção das atividades escolares ou outras discussões que efetivamente não trazem contribuições para o planejamento pedagógico. Sobre o HTPC na escola, algumas professoras comentam: 
Prof. (UE13): "Na maioria das vezes ele é dominado pela coordenadora com muitas informações e papeladas da Diretoria. Não conseguimos conversar e trocar idéias. Acho que a Diretoria devia deixar de tanta burocracia e deixar as escolas um pouco mais livres".

Prof. (UE15): "Estamos sempre "apagando incêndios", discutindo relatórios a serem entregues, avisos importantes e informações oriundas da Diretoria, da Secretaria da Educação e da própria direção da escola, impossibilitando assim a troca de experiências".

Prof. (UE19): "Na minha escola ele serve para passar recados. Ás vezes, discutimos sobre o comportamento de alguns alunos, mas na maioria das vezes ele serve para fazer cobranças e passar burocracias encaminhadas pela D.E. Logo é muito pouco utilizado para a reflexão de reais necessidades do corpo docente e discente da U.E."

Em algumas escolas, os professores disseram que utilizam parte desse horário para estudo de alguns documentos, mas que geralmente acabam ficando apenas na leitura, sem grandes discussões. Segundo Follari (1999) o trabalho com projetos em Educação Ambiental é fruto de árduo trabalho de comunicação mútua entre aqueles que provêm de disciplinas diferenciadas ou daqueles com interesses comuns e que requer portanto, muito trabalho de preparação fora da aula, tanto para assegurar a confluência dos conteúdos, como para preparar de modo concreto as atividades docentes rotineiras. Nesse sentido, acreditamos que os HTPCs poderiam contribuir para trabalhos desse tipo. Talvez falte uma reflexão mais aprofundada sobre qual a verdadeira função deste HTPC na escola e qual o verdadeiro papel do Coordenador Pedagógico, uma vez que ele é o responsável por esse horário de trabalho coletivo.

Para algumas professoras, a questão financeira é outro ponto bastante importante para a determinação do sucesso com os projetos de Educação Ambiental. Justificam que a escola quase nunca tem recurso para fornecer materiais, montar uma exposição, principalmente para realização de atividades extra-classe, referindo-se aqui a saídas da escola para outro local.

Prof. (UE11): "Fica difícil trabalhar assim, nunca tem dinheiro para nada, fiz uma atividade com meus alunos sobre a importância de se 
preservar a fauna, principalmente de alguns animais que estão em extinção e queria levá-los ao Zoológico para verem alguns desses animais de que falamos. A entrada para os alunos do Ensino Fundamental no Zoológico é gratuita, mas não tinha dinheiro para o aluguel do ônibus e também não tive a autorização da escola para pedir o dinheiro para os alunos. A gente continua fazendo esses trabalhos porque gosta muito e acredita que isso é importante para os alunos mas, às vezes, a gente desanima".

A deficiência de infra-estrutura, a falta de recursos, de pessoal, a dificuldade da escola estabelecer parcerias, são fatores que podem condicionar o fim prematuro de muitos projetos. Infelizmente, o desânimo citado pela professora, raras exceções, pode acabar gerando uma falta de inspiração que as dificultam de perceber que são muitas as possibilidades de trabalho na escola.

Comentei que também como professor da rede pública estadual, sabia dessas dificuldades, inclusive das financeiras, mas que isso não podia ser desculpa para a não participação ou realização de atividades ou projetos de Educação Ambiental. Citamos algumas experiências do próprio grupo que mostrou a possibilidade de realizar atividades muito significativas por meio do exercício da observação e apreensão de significados do próprio espaço em que vivemos. A comunidade a que pertencemos, o entorno da escola e a própria escola pode se constituir em excelente recurso para o desenvolvimento dessas atividades, concluindo que não é necessário ter muitos recursos nem mesmo ir para outros locais longe da escola para desenvolvermos as atividades e projetos de Educação Ambiental. Não é desprezível o argumento quanto às condições materiais uma vez que é inegável que sua falta atrapalha a exploração de algumas metodologias, mas as trocas de experiências, de saberes e aprendizados independem dessa condição.

Para Segura (2001), o estudo da realidade próxima coloca-se como uma possibilidade real de leitura integrada do ambiente que conduz à reflexão a respeito das soluções para problemas concretos. Não se restringe ao estudo da natureza in loco; trata-se do levantamento dos principais problemas/potencialidades de uma dada realidade, a partir de uma leitura que leva em conta a contribuição das ciências, como do conhecimento popular e local, a fim de se propor estratégias para equacionar esses problemas e conseguir melhorias.

Outro ponto que merece ser retomado nesta análise, refere-se à falta de avaliação nos projetos. Sem uma avaliação contínua, eles acabam ficando às vezes sem sentido, tanto para 
professores como para alunos, que não sabem ou não entendem o porquê de algumas atividades. Até mesmo projetos bem sucedidos acabam não se repetindo nos anos subseqüentes por falta de uma avaliação mais sistemática. A avaliação nesses casos tem como funções principais verificar se os objetivos foram atingidos, se a metodologia de trabalho foi adequada para que o mesmo possa sofrer reformulações necessárias para o seu aprimoramento. Essa falta de avaliação também pode fazer com que alguns projetos acabem prematuramente. Por fim, refletiremos um pouco sobre a questão da interdisciplinaridade nos projetos de Educação Ambiental.

Quando questionadas sobre como preferem trabalhar com as atividades de Educação Ambiental, se de maneira interdisciplinar ou apenas na disciplina de Ciências, todas as professoras disseram que trabalham de maneira interdisciplinar.

$\mathrm{Na}$ análise dos projetos elaborados pelas professoras, não identificamos o nome de nenhuma disciplina específica para o desenvolvimento das atividades, mas pudemos observar uma forte relação com as disciplinas de Ciências, Geografia, Língua Portuguesa e Educação Artística. Enquanto os textos informativos relacionavam-se com o conteúdo de Ciências e Geografia, em todos os casos, a elaboração e a reescrita coletiva de texto ficava a cargo da disciplina de Língua Portuguesa e o registro por sua vez, a cargo da disciplina de Educação Artística. Uma professora chegou a comentar a necessidade de ter que registrar tudo separado, ou seja, cada atividade em uma disciplina.

Prof. (UE05): “O trabalho foi feito no todo, mas na hora do registro tem que ser separado porque temos que registrar o que foi trabalhado em cada disciplina. É uma norma fazer esse registro assim, pois somos cobradas pelo que trabalhamos em cada disciplina".

O relato dessa professora deixa claro que apesar das informações e orientações, na prática pouca coisa mudou, principalmente quanto ao trabalho interdisciplinar. Os currículos escolares continuam sobrecarregados de conteúdos hierarquizados, desarticulados da realidade ou com uma leitura simplista da mesma, com acúmulo de informações, avaliações quantitativas e superficiais que não estimulam os alunos a conhecer, investigar e descobrir sua realidade.

Quando questionadas sobre o que elas entendem por trabalho interdisciplinar, uma professora respondeu: 
Prof. (UE17): "Por trabalho interdisciplinar eu entendo que tendo um tema principal eu consiga integrá-lo com todas as matérias do currículo base pois cada matéria tem a sua especificidade e pode contribuir com algum conhecimento".

Nesta mesma linha de pensamento, outra professora comenta:

Prof. (UE11): “Trabalho interdisciplinar é fazer uma integração envolvendo todas as disciplinas como Português, Matemática, Ciências, Geografia, História, Artes e Educação Física. Tem que envolver todas as disciplinas".

Através dessas falas, podemos concluir que o que é feito e desenvolvido como trabalho interdisciplinar, infelizmente não passa de uma integração de disciplinas, confusão esta já alertada por Tristão (1992) ou uma justaposição arbitrária de disciplinas e conteúdos segundo Frigotto (1995). Nesse sentido, os projetos apresentados pouco contribuirão para a formação de um cidadão crítico e consciente uma vez que se resumem à união de várias atividades interligadas com caráter informativo que podem levar apenas a uma mudança de comportamento. Os projetos como foram apresentados e desenvolvidos não privilegiam a reflexão, a crítica e as mudanças de atitudes. Essas conclusões referem-se à análise dos seis projetos elaborados e desenvolvidos durante as oficinas e por isso não podemos generalizar que todas as atividades ou os projetos de Educação Ambiental realizados pela professoras do Ensino Fundamental I da Diretoria Centro Sul, tenham esse caráter. Tivemos o relato de atividades e projetos muito bem elaborados e sucedidos, preocupados em levar os alunos a refletirem e proporem possíveis soluções para problemas do dia-a-dia. Mas isso ainda nesse grupo se configura como atividades esporádicas e pontuais.

O trabalho escolar voltado para a implementação de propostas metodológicas interdisciplinares exige a conjunção de uma série de fatores a começar pelo reconhecimento de que a questão ambiental perpassa por várias áreas do conhecimento. Para Assis (1991) a dificuldade dos professores em trabalharem com projetos interdisciplinares é reforçada pelo fato de que a própria formação desses professores também não foi interdisciplinar.

Para Frigotto (1995), o limite mais sério, para a prática do trabalho pedagógico interdisciplinar, situa-se na dominância de uma formação fragmentária, positivista e metafísica do educador e nas condições de trabalho - divisão e organização - a que está 
submetido. Ainda para o autor, o especialismo na formação e o pragmatismo e ativismo que impera no trabalho pedagógico constituem-se em resultado e reforço da formação fragmentária e forças que obstaculizam o trabalho interdisciplinar.

Para Machado (1997), valores, utopias e projetos constituem ingredientes da idéia de educação que por sua vez, tem seu significado associado à ação de conduzir a finalidades socialmente prefiguradas, o que pressupõe a existência e a partilha de projetos coletivos. Para ele, sem o enraizamento em valores maiores que orientem os projetos e as ações educacionais, ao invés de planejamentos excessivamente minuciosos ou de alterações radicais na legislação em vigor, os projetos mais bem intencionados terminam por perder toda a potencialidade transformadora, tendendo a confundir-se com planos de ação de cunho meramente burocrático e correndo o risco de tornar-se demasiadamente rígidos, o que deve ser por sua natureza, flexível, adaptável e variável.

Não é obrigação da escola resolver problemas ambientais como a questão do lixo, da poluição do ar, da água, do tratamento de esgoto etc., mas é obrigação da escola desenvolver

o interesse pelo conhecimento e a capacidade de julgamento nas pessoas que compartilham a mesma realidade, para que elas possam contribuir na construção coletiva de um ambiente melhor, ou seja, é obrigação da escola desenvolver nos cidadãos a consciencia de seus direitos e deveres; sendo assim, o trabalho com projetos interdisciplinares de Educação Ambiental pode muito contribuir para essa função.

\section{PRÁTICAS DE EDUCAÇÃO AMBIENTAL E AS ATIVIDADES DE ENSINO E APRENDIZAGEM}

Comentadas algumas das principais questões relacionadas à viabilização do trabalho com projetos e o desenvolvimento de práticas interdisciplinares, iniciaremos uma análise e reflexão sobre as práticas elaboradas e desenvolvidas pelas professoras, relacionando-as com as atividades de ensino e aprendizagem na perspectiva da Psicologia Histórico-Cultural. Para tanto, retomaremos algumas das observações feitas quanto às dificuldades do grupo em trabalhar com projetos, uma vez que estas, a nosso ver, podem interferir na caracterização e realização de atividades de ensino e aprendizagem.

Uma dessas dificuldades refere-se à questão da intencionalidade dos professores na realização das atividades ou projetos de Educação Ambiental, que como já falamos pode existir, estar presente em seu planejamento mas não se realizar, e a outra dificuldade relaciona-se ao papel da mediação do professor, quase sempre limitada, nos projetos 
analisados, a uma conversa inicial e depois à coordenação de uma seqüência de atividades e tarefas a realizar que pouco se aproximavam de práticas interdisciplinares ou de um intercâmbio entre um saber e um fazer como já discutimos.

A partir dessa análise inicial e recordando o objetivo maior de uma atividade de ensino, que em linhas gerais seria o de possibilitar o intercâmbio entre o saber e o fazer, contribuindo para a superação da alienação presente no modo de produção capitalista, podemos concluir que os projetos elaborados não se constituíam como atividades de ensino, ou seja, do ponto de vista pedagógico, pouco contribuíam como processo cognitivo para a formação da consciência.

Quanto ao papel da mediação, recordando Soares (2005) e Oliveira, Almeida e Arnoni (2007), o professor não pode se limitar a observar e dar suporte para as crianças ao longo das atividades, mas precisa estar presente interagindo, estimulando, mobilizando e desafiando o grupo para a resolução de diferentes atividades fazendo com que eles superem o plano imediato no mediato, ou seja, tenham acesso ao conhecimento produzido historicamente pela humanidade. O papel da mediação entendida como um processo pedagógico fundado no agir comunicacional docente que pode levar a mudanças qualitativas na aprendizagem.

Com relação às atividades de aprendizagem, recordando Davidov (1986) elas não estão ligadas simplesmente ao desenvolvimento de uma habilidade específica, mas como propõe o autor, para além do aprendizado específico de uma habilidade qualquer, elas devem levar os alunos a "aprender a aprender", onde o professor pode levar o aluno a dar forma ao método teórico através do qual um problema pode ser resolvido numa situação de aprendizagem, chamada por ele de problema de aprendizagem. Sendo essas as características de uma atividade de aprendizagem segundo Davidov (1986), podemos concluir que os projetos apresentados precisam de algumas reestruturações para se enquadrarem como tal, principalmente quanto à intencionalidade das professoras e a forma como elas desenvolvem seus projetos. Para que as atividades de aprendizagem possam ocorrer, faz-se necessário, como já dissemos anteriormente, uma organização específica do ensino, no sentido de garantir que momentos coletivos possam ocorrer. Daí a importância do trabalho com projetos.

Da mesma forma que os projetos analisados não se caracterizam como atividades de ensino e de aprendizagem, na perspectiva histórico-cultural, eles também não se caracterizam como atividades orientadoras de ensino proposta por Moura e Lanner de Moura. No caso específico das atividades orientadoras de ensino, além da falta da uma intencionalidade do professor, não observamos a explicitação de uma situação problema, momentos de interação entre as crianças, o professor e as diferentes fontes para possíveis formas de resolução do 
problema apresentado e momentos coletivos de síntese teórica das resoluções encontradas. Acreditamos que a ausência desses fatores pode-se justificar pelas dificuldades do grupo em elaborar e desenvolver o trabalho com projetos.

Mais uma vez, queremos ressaltar que essas observações referem-se à análise dos seis projetos elaborados pelas professoras durante a realização das oficinas e suas falas sobre a aplicação e desenvolvimento dos mesmos, o que não significa dizer que todo o trabalho realizado pelas professoras, voltado para a questão ambiental apresente os mesmos problemas, ou seja, de que nada possa ser caracterizado como uma atividade de ensino, atividade de aprendizagem ou atividade orientadora de ensino. Tivemos o relato durante as oficinas de importantes atividades e projetos de Educação Ambiental, que se caracterizavam perfeitamente como as atividades analisadas acima, o que reforça mais uma vez a idéia da existência de muitos trabalhos pontuais, de projetos que não se articulam ao projeto políticopedagógico da escola, sem continuidade, constituindo-se como experiências isoladas e tentativas pontuais.

\section{EDUCAÇÃO AMBIENTAL E A FORMAÇÃO DOCENTE}

Como já citamos, nosso objetivo principal com o desenvolvimento das oficinas era inicialmente o de verificar quais as bases teóricas e as concepções que sustentavam as práticas de Educação Ambiental, bem como analisar o desenvolvimento e a avaliação dessas práticas, mas logo de início percebemos o quanto tais encontros estavam sendo importantes na formação de cada professora. Elas começaram a perceber que compartilhavam as mesmas dúvidas e dificuldades e que aqueles momentos coletivos de estudo e reflexão podiam possibilitar o surgimento não só de novas idéias e novas práticas, mas podiam contribuir principalmente com uma visão mais crítica com relação a alguns temas relacionados ao meio ambiente.

Inicialmente, podíamos observar com certa freqüência na fala das professoras, a reprodução de um discurso dominante, principalmente com as questões relacionadas ao lixo e à reciclagem. Defendiam e estimulavam práticas de reciclagem como uma mudança de comportamento, mas em nenhum momento discutiam a questão do consumismo desenfreado dos modos de produção capitalista para uma mudança de atitude.

De acordo com Oliveira, Almeida e Arnoni (2007) é possível supor que no trabalho pedagógico a alienação se processa no modo de o professor produzir e conduzir o plano da escola (de curso, de disciplina e de aula), por exemplo. O plano escolar é o registro de um 
planejamento, de um projeto que o professor elabora a partir do estudo da realidade da escola, de idéias, de ações, de ações para frente (projetos), ações pretendidas para transformar a realidade atual da referida escola. Assim, para transformar aspectos indesejáveis da realidade escolar é a intencionalidade das ações educativas pensadas pelo professor e transcritas em metas e objetivos do plano escolar, que articulam, de forma consciente, a ação pretendida e a consciência dessa ação, no entanto, essa intencionalidade pode diluir-se quando o plano escolar se torna um documento meramente burocrático que se presta exclusivamente ao atendimento dos prazos e aos interesses dos gestores (os que pensam), separando-se dos interesses dos docentes (os que executam). O desafio que se coloca para a comunidade escolar é a possibilidade de se manter presente a intencionalidade registrada no plano escolar, de operacionalizá-lo diariamente, entendendo a tensão dialética que se estabelece entre a intencionalidade presente nas metas e nos objetivos e a realidade escolar (teórica e prática) (OLIVEIRA, ALMEIDA e ARNONI, 2007).

A partir desta constatação, propusemos a leitura e a reflexão de um texto ${ }^{48}$ que fala sobre o significado ideológico da reciclagem da latinha de alumínio, uma vez que esta ainda é uma prática ainda bastante comum nas escolas. Com o passar dos encontros e das discussões, começamos a observar uma visão mais crítica e consciente principalmente no que se refere à ligação dos problemas ambientais com os elementos sociais, culturais e, sobretudo econômicos. Aos poucos, as professoras passaram a perceber que apesar de uma grande boa vontade em contribuir para a formação de um aluno crítico e consciente de seus direitos e deveres em sociedade, sobretudo de reconhecerem os problemas ambientais e de poderem propor soluções para tais problemas, na maioria das atividades elas apenas reproduziam uma ideologia dominante.

Com relação a contribuição da leitura e reflexão sobre o texto, uma professora disse:

Prof. (UE13): "Meu Deus, como a gente é manipulada sem perceber. Acreditamos que sabemos das coisas, que estamos fazendo tudo da melhor forma e olha o que descobrimos. Sempre defendi a reciclagem, falei da sua importância, mas nunca me toquei para a questão do consumismo, do interesse econômico por trás disso, do capitalismo e principalmente para a necessidade de reduzir nosso consumo. A partir

\footnotetext{
${ }^{48}$ Referência já indicada no conteúdo da segunda oficina na página----do capítulo II.
} 
de agora irei tratar da reciclagem de forma diferente, pois o meu foco será o consumo, ou seja, a sua diminuição”.

Durante as oficinas, algumas professoras demonstraram o desejo da intermediação de um coordenador ou de um especialista para orientar os trabalhos e os projetos de Educação Ambiental. A respeito disso, Fazenda (1994) sugere que a intermediação de um coordenador competente visando à integração do grupo é uma alternativa válida. Outra possibilidade de colaboração seria o estabelecimento de parcerias com as Universidades, onde os pesquisadores pudessem estabelecer um diálogo permanente com os professores. Nesse sentido Krasilchik (1987) diz que os pesquisadores devem ir à escola, conviver com estudantes, professores e administradores em seu habitat, para poderem mais efetivamente colocar suas déias em prática e também para analisarem a propriedade e a conveniência de tais idéias.

De acordo com as avaliações, as oficinas contribuíram para a construção de um novo olhar mais crítico e reflexivo com relação às questões ambientais

Prof. (UE10): “ Sempre que muda nossa essência, muda também nosso entorno, pois nossas aulas são o reflexo do que pensamos, aprendemos e somos enquanto pessoas e profissionais. Agora consigo refletir mais sobre algumas questões e isso faz com que eu seja mais crítica. Cresci e meu trabalho pedagógico por conseguinte. São novas atitudes, novos olhares, novas mensagens passadas."

Prof. (UE15): “Esta oficina contribuiu para uma visão mais crítica sobre a Educação Ambiental, percebo que é preciso ter um cuidado especial quando se fala sobre esse assunto com as crianças para não passarmos uma visão do discurso dominante que leva apenas a uma mudança de comportamento. Percebi que é preciso mais leitura e pesquisa por parte dos professores, mais estudo."

Prof. (UE17): “ A oficina de Educação Ambiental me ajudou a enxergar a importância que eu tenho como educadora, para desenvolver atividades que ajudem os meus alunos a compreender algumas questões ambientais e que possam numa ação coletiva 
transformar o ambiente em que vivemos. Me sinto mais crítica e preparada para conseguir atingir esses objetivos que hoje depois de várias reflexões estão mais claro para mim."

As professoras passaram a se sentir mais seguras para discutir assuntos relacionados com o meio ambiente, o que sem dúvida, se refletirá em práticas mais objetivas e produtivas.

Prof. (UE03): "Estou mais feliz. Mudei minha fala perante meus alunos e também para com os colegas de trabalho. Transmito uma visão mais crítica e construtiva".

Passaram a perceber a importância de uma formação continuada, principalmente em relação às questões ambientais, sugerindo a formação de um grupo de estudo que pudesse tratar de questões importantes do trabalho pedagógico como o trabalho com projetos e a questão da interdisciplinaridade.

Segundo a Professora da UE 09:

"precisamos agora formar um grupo de estudo que possa dar continuidade a esse nosso trabalho inicial. Conseguimos perceber hoje muitas coisas diferentes relacionadas com a questão ambiental, mas ainda precisamos estudar e refletir muito mais sobre tudo isso, principalmente sobre o trabalho com projetos e sobre as práticas interdisciplinares. Estamos mais seguras, mais conscientes, mas ainda precisamos trabalhar em grupo para compartilharmos além das dúvidas, das incertezas e das tristezas, as nossas alegrias”.

Relembrando Chauí (1982) "alegria é o que sentimos quando percebemos o aumento da compreensão de nossa realidade, isto é, de nossa força interna e capacidade para agir".

Diante dessas falas e observações, podemos concluir que existe a necessidade de se investir nos cursos de formação e aumentar a oferta de cursos de aprimoramento e capacitação, aqui em específico para se discutir questões relacionadas ao meio ambiente. 


\section{CONSIDERAÇÕES FINAIS}

"Nossa vida é a soma dos resultados das escolhas que fazemos, consciente ou inconscientemente. Se somos capazes de controlar nosso processo de escolher, podemos controlar todos os aspectos de nossas vidas. Desfrutamos, então, da liberdade que vem do fato de estarmos em controle de nós mesmos”.

Robert F. Bennet.

As discussões sobre as questões ambientais permeiam hoje toda a sociedade adquirindo uma dimensão mundial com um consenso de que é necessário e urgente medidas efetivas no sentido de reverter o quadro de degradação ambiental em que se encontra o nosso planeta. Também há um consenso em relação aos posicionamentos expressos em textos técnicos e legais de que a Educação Ambiental tem papel fundamental nesse processo de mudança. Assim, podemos considerá-la como uma práxis em formação, que relaciona várias concepções de mundo submetida à diversas orientações metodológicas.

Apesar de uma aparente introdução de mudanças, percebemos que a escola ainda continua com uma prática pedagógica tradicional em vários aspectos, o que pode se justificar observando-se o modo como as mudanças foram introduzidas, desconhecendo a realidade do sistema e ignorando os verdadeiros sujeitos do processo de ensino e de aprendizagem: educadores e educandos.

O processo de complexidade dos temas ambientais na sociedade obriga a reorientação dos temas escolares, pois necessitam de uma dinâmica pedagógica interdisciplinar de abordagem crítico-social e histórica. Essa postura metodológica e pedagógica estabelece uma nova ética entre o sujeito e o seu meio, porque a ele também é imputada a responsabilidade da ação, da prevenção e da solução de problemas ambientais, já que é visto como parte integrante do meio ambiente e não mais como seu dominador. Dessa forma, a dimensão ambiental na prática educativa não pode ser encarada como mais uma disciplina do currículo ou um tipo especial de educação, mas uma das dimensões norteadoras da educação geral, compreendendo os processos através dos quais o indivíduo e a coletividade constroem valores sociais, conhecimentos, atitudes e habilidades.

Não devemos criar a ilusão de que a Educação Ambiental, enquanto prática educativa e social seja capaz de resolver todos os problemas ambientais, uma vez que essa não é sua função nem seu objetivo maior. A Educação Ambiental tem como função a transformação. Para além das mudanças de hábitos e comportamentos, ela deve favorecer a formação de uma 
nova mentalidade para a construção de uma sociedade sustentável que fomente novas utopias e mostre que é possível realizar mudanças para melhor, seja na relação com o conhecimento, nas relações interpessoais, na relação escola-sociedade, seja na relação sociedade-ambiente.

Embora se reconheça a escola como um lugar privilegiado para o desenvolvimento da Educação Ambiental, cada indivíduo, independentemente de seu grau de escolaridade, idade, profissão, formação e local de trabalho, pode constituir-se como um agente de mudança.

Se a Educação Ambiental trata da questão holística ligada diretamente a aspectos históricos, sociais, políticos e econômicos da humanidade, ela sintetiza o que se procura alcançar em nível educacional geral na sociedade, assim ela deve ser vista em um contexto mais amplo de educação geral, não fragmentada.

Nesse sentido, o salto qualitativo que se espera é que o trabalho pedagógico, e em específico com as práticas de Educação Ambiental, não seja só o de ensinar conteúdos, mas também o de ensinar a pensar. Concordando com Freire (1996) significa estar consciente das incertezas e buscar respostas na vida. Essa é a essência da atuação do professor-pesquisador.

Nessa pesquisa, podemos identificar vários fatores que dificultam a realização de atividades e projetos de Educação Ambiental na escola de Ensino Fundamental I. Dentre as principais podemos citar: uma educação escolar ainda tradicional, o desconhecimento sobre Educação Ambiental, a formação deficiente do docente, baseada sobretudo na ação individual e na falta de diálogo entre as áreas de conhecimento e entre os professores e a dificuldade de se trabalhar com projetos interdisciplinares, dentre outras.

Confirmamos que realmente há um grande descompasso e distanciamento entre o que é discutido e proposto pela escola e para a escola com aquilo que realmente vem sendo feito. É preciso que o debate seja aberto para a toda a sociedade e em específico com todos os professores envolvidos para que as propostas de mudança realmente possam ser traduzidas em ações e não só ficarem no discurso superficial continuando com um processo educativo que pouco estimula a participação e a solidariedade.

Concluímos que no plano metodológico, a perspectiva definidora da Educação Ambiental é a interdisciplinaridade, assim, pensar em Educação Ambiental escolar é antes de tudo, pensar em um projeto pedagógico interdisciplinar cujas práticas convirjam para uma perspectiva coletiva de cunho político e totalizador. É educação comprometida com a prática social e o desenvolvimento contínuo da cidadania, numa interação dialógica com a comunidade. É a busca de caminhos pessoais e coletivos que levem ao estabelecimento de relações econômicas, sociais e culturais cada vez mais adequadas à vida no planeta. 
Precisamos repensar as formas tradicionais de ensinar e de aprender, fortalecendo a relação entre o aluno e a escola, o que perpassa pela noção de pertencimento, que procura enraizar a identificação do indivíduo com um lugar ou uma idéia, sustentando a vontade de tomar iniciativa em prol de uma causa comum.

Com relação ao desconhecimento sobre a Educação Ambiental, acreditamos que devese estimular a participação constante dos professores nas atividades de orientação pedagógica, uma vez que isso alimentaria a troca de saberes e experiências transformando a escola em espaço de formação. Ainda nesse sentido, outro caminho seria o de se repensar a função e os objetivos das HTPCs na escola, que poderiam contribuir substancialmente para a formação continuada dos professores em serviço.

Quando falamos da formação deficiente do professor, não queremos destacar uma deficiência específica de trabalhar com um conteúdo ou outro, em aplicar uma metodologia ou outra, estamos aqui nos referindo a uma deficiência maior em compreender a prática educativa na sua complexidade, nas redes de relações que se estabelecem entre educadores e educandos, ou seja, na sua práxis, que transcenda o horizonte das ações individuais e busque envolvimento com as ações coletivas, que desencadeie uma ação transformadora, compartilhando as responsabilidades pelo bem comum e que considere os alunos como pessoas e a realidade como um espaço de reflexão-ação-transformação.

Verificamos que a falta de diálogo na escola, compromete sem dúvida alguma uma educação para a cidadania, autonomia, pertencimento e fundamentalmente para a formulação de projetos de Educação Ambiental. Falta de diálogo que muitas vezes pode ser justificada pela estrutura educacional que organiza a rotina da escola e pela visão reduzida de educação por parte de alguns professores. Na medida em que não há diálogo, os objetivos das atividades e dos trabalhos coletivos não são partilhados, os alunos não se sentem estimulados a conhecer, investigar e descobrir novas realidades, o que compromete seriamente o trabalho com projetos que mesmo sendo realizados, pouco contribuem para a formação de cidadãos críticos e conscientes.

A falta de comunicação inibe a criatividade, porque não estimula a troca e as possibilidades de participação. O seu exercício, ao contrário, pode resultar em novas possibilidades, novos conhecimentos, desejo de trabalhar em grupos, de partilhar que, a nosso ver, são ingredientes essenciais para os projetos de Educação Ambiental.

Diante disso, o que devemos esperar da escola? O que ela poderá fazer para cumprir seu papel na formação de uma consciência ambiental? Acreditamos que se ela conseguir proporcionar uma leitura crítica da realidade, estimular a participação efetiva dos alunos na 
aprendizagem e chamar a responsabilidade de cada um para o objetivo de ampliar e melhorar a qualidade de vida, ela estará cumprindo esse papel. Para tanto, o ideal seria os professores se aproximarem da teoria a partir das necessidades da sua realidade, dos seus alunos, para então desenvolver habilidades e clarear a compreensão a fim de consolidar um pensamento crítico e um trabalho que contribua substancialmente para a formação de cidadãos atentos e conscientes das questões ambientais.

Diante de todas as dificuldades observadas e com o objetivo de fortalecer as práticas de Educação Ambiental na escola, principalmente no Ensino Fundamental I, vamos sugerir alguns possíveis caminhos:

- Renovar e incrementar os processos de formação docente e de capacitação visando o trabalho com projetos interdisciplinares;

- Estabelecer parcerias com Universidades, Centros de Pesquisa e com a comunidade;

- Estimular a produção de material didático elaborado em parceria com os professores;

- Rever os Projetos Político-pedagógicos da escola afim de adequá-los às novas exigências e realidades da sociedade;

- Estimular o diálogo e o senso de solidariedade entre direção, coordenação, professores, alunos e toda a comunidade local para que se possa planejar, discutir soluções e decidir de forma participativa produzindo assim um conhecimento satisfatório que ilumine a realidade de significados;

- Assumir o compromisso de mudança para uma situação melhor.

Sabemos que devido a toda complexidade do processo educativo e das suas múltiplas relações, a viabilização desses caminhos nunca se constituirá numa tarefa simples e cômoda, mas acreditamos que este conjunto de sugestões/ações possam se constituir num incremento qualitativo no processo educativo que visa formar cidadãos críticos e conscientes de sua realidade.

A escola deve ser desafiada a mudar a lógica da construção do conhecimento, pois a aprendizagem agora ocupa toda a nossa vida e confere sentido à cultura cooperativa, onde a interdependência é o cerne das relações sociais estabelecidas. O ensino deve voltar-se para a compreensão e o desempenho de um mundo em mudança, de forma a maximizar a aprendizagem, estimular a criatividade e a capacidade de transformação. 
O que realmente desejamos é que cada comunidade, escola, professor, cada pessoa envolvida, interessada e compromissada com um mundo melhor, se perceba em algumas de nossas reflexões durante nosso caminhar e consiga prosseguir e aprimorar a sua própria caminhada pelas práticas de Educação Ambiental.

Lembrando Machado (1997, p. 77) no terreno educacional, uma necessária semeadura de valores é imprescindível para a produção de projetos legítimos, projetos estes que "nos alimentam, nos impulsionam para a frente, nos mantêm vivos".

Segundo a Professora da UE 17:

"Nada é impossível quando temos um amigo para caminhar do nosso lado, não só para dividir nossas dúvidas, nossas incertezas, nossas tristezas, mas também para comemorar nossas conquistas, nosso crescimento e principalmente nossa alegria de viver e de poder contribuir para um mundo melhor". 


\section{REFERÊNCIAS}

ALMEIDA, J.L.V.; OLIVEIRA, E.M.; ARNONI, M.E.B. Mediação dialética na educação escolar: teoria e prática. São Paulo: Loyola, 2007.

ARNONI, M.E.B. A mediação, suas implicações metodológicas e o trabalho da temática ambiental. Tradução da própria autora. In: First World Environmental Congress de Portugal (First),2003, Espinho. Discursos: Língua, Cultura e Sociedade (número especial). Tendências actuais em Educação Ambiental. Universidade Aberta. Porto, Portugal, 2003. v. único. p.213222.

ASSIS, Eveline S. A Unesco e a educação ambiental. Brasília, v.11, n. 49, p. 59-62, jan/mar, 1991.

BECK, Ulrich. A Reinvenção da Política. In: GIDDENS, Anthony. Et al. Modernização Reflexiva. São Paulo: Unesp, 1997.

. Teoria de la sociedad del riesgo. In: BERIAN, J. Lãs consecuencias perversas de la modernidad. Barcelona: Anthropos, 1996.

. On the logic of wealth distribuition and risk distribuitions. In: Beck, Ulrich. Risk society. Londres: Sage, 1994.

BITTENCOURT, Circe Maria Fernandes. A Proposta de Educação Ambiental e as muitas dúvidas. In: PONTUSCHKA, Nídia Nacib (org.). Um projeto... tantas visões: Educação Ambiental na Escola Pública. São Paulo: LAPECH/FEUSP, 1996. p. 9-16.

BIZERRIL, M.X.A.,FARIA, D.S. Percepção de professores sobre a educação ambiental no ensino fundamental. Revista Brasileira de Estudos Pedagógicos. Brasília, v.82, n.200/201/202, p. 57-69, jan./dez, 2001.

BOFF, Leonardo. A águia e a galinha: uma metáfora da condição humana. $3^{\mathrm{a}}$ ed. Petrópolis: Vozes, 1997.

BRASIL. Secretaria de Educação Fundamental. Parâmetros Curriculares Nacionais: meio ambiente e saúde (vol. 9). Brasília: Ministério da Educação e do Desporto/ Secretaria de educação fundamental, 1997.

- Secretaria de Educação Fundamental. Parâmetros Curriculares Nacionais: Introdução (vol. 1). Brasília: Ministério da Educação e do Desporto/ Secretaria de educação fundamental, 1997 a.

BUARQUE, C. A desordem do progresso. São Paulo: Paz e Terra, 1990.

CARVALHO, Isabel Cristina de Moura. Educação Ambiental: a formação do sujeito ecológico. São Paulo: Cortez, 2004.

Territorialidades em luta: uma análise dos discursos ecológicos. São Paulo, Instituto Florestal. Série Registros, n. 9, 1991. 
CASTRO, R. S.; SPAZZIANI, M. L.; SANTOS, E. P. Universidade, Meio Ambiente e Parâmetros Curriculares Nacionais. In: LOUREIRO, C. F. B., LAYRARGUES, P. P., CASTRO, R. S. (Orgs). Sociedade e meio ambiente: a educação ambiental em debate. $2^{\mathrm{a}}$ ed. São Paulo: Cortez, 2002. p. 157-176.

CHAUÍ, Marilena. O que é educador hoje? Da arte à ciência: a morte do educador. In: BRANDÃO, C. R. (org.). O educador: vida e morte. Rio de Janeiro: Graal, 1982.

CHIZZOTTI, Antonio. Pesquisa em Ciências Humanas e Sociais. $6^{\text {a }}$ edição - São Paulo: Cortez, 2003.

DANIELS, Harry. Vygotsky e a Pedagogia. Tradução Milton Camargo Mota. São Paulo: Loyola, 2003.

DAVIDOV, V. V. La enseñanza escolar y el desarrollo psíquico. Moscú: Progresso, 1988. 1986. Problemas da aprendizagem em vias de desenvolvimento. Moscou: Pedagoguika,

DIAS, Genebaldo Freire. Educação Ambiental: princípios e práticas. $7^{\text {a }}$ edição. São Paulo: Gaia, 2001.

DUARTE, Newton. A teoria da atividade como uma abordagem para a pesquisa em educação. Perspectiva, Florianópolis, v. 21, n. 02, p. 1-21, jul./dez. 2003.

Concepções afirmativas e negativas sobre o ato de ensinar. Cadernos CEDES, Campinas, v.19, n. 44, p.85-104, abr.1998.

ELKONIN, D. B. The psychology of preschool children. Cambridge, Mass.: MIT Press, 1971.

FAZENDA, Ivani C. A. Interdisciplinaridade: história, teoria e pesquisa. Campinas: Papirus, 1994.

FERREIRA, N. T. Cidadania: uma questão para a educação. Rio de Janeiro: Nova Fronteira, 1993.

FOLLARI, R. La interdisciplina em la educación ambiental. Tópicos em Educación Ambiental, México, v.1, n. 2, p. 27-35, 1999.

FREIRE, Paulo. Pedagogia do Oprimido. 12a ed. Rio de Janeiro: Paz e Terra, 1983.

Pedagogia da autonomia. Coleção Leituras. São Paulo: Paz e Terra, 1996.

FREITAS, M. T. A. A abordagem sócio-histórica como orientadora da pesquisa qualitativa. Cadernos de Pesquisa, n. 116, p. 21-39, julho/2002.

FRIGOTTO, Gaudêncio. A interdisciplinaridade como necessidade e como problema nas ciências sociais. In: ARI, P.J; BIANCHETTI, L. (Orgs). Interdisciplinaridade: para além da filosofia do sugeito. Petrópolis, RJ: Vozes, 1995. 
GARNIER, C; BEDNARZ, N; ULANNOVSKAYA, I. Duas diferentes visões da pesquisa em Didática. In: GARNIER, C; BEDNARZ, N; ULANNOVSKAYA, I (Orgs.). Após Vygotsky e Piaget: Perspectives Social e Construtivista Escolas Russa e Ocidental. Tradução: Eunice Gruman. Porto Alegre: Artmed, 2003.

GIDDENS, Anthony. As conseqüências da modernidade. São Paulo: Unesp, 1991.

GOLDER, Mario. Angustia por la utopia. Buenos Aires: Ateneo Vigotskiano de la Argentina, 2002.

GONZÁLEZ-GAUDIANO, Edgar. Interdisciplinaridade e educação ambiental: explorando novos territórios epistémicos. In: SATO, Michele; CARVALHO, Isabel Cristina Moura e cols. Educação Ambiental: pesquisa e desafios. Porto Alegre: Artmed, 2005.

GUIVANT, J. A trajetória das análises de risco: da periferia ao centro da teoria social. Revista Brasileira de Informação Bibliográfica em Ciências Sociais. Rio de Janeiro: Relime Dumará, 1998.

HERCULANO, S. C.; PORTO, M.F.S.; FREITAS,C. M. (Orgs). Qualidade de vida e riscos ambientais. Niterói: EdUFF, 2000.

JACOBI, Pedro Roberto. Diálogo, sustentabilidade e utopia. In: SEGURA, Denise de Souza Baena. Educação Ambiental na escola pública: da curiosidade ingênua à consciência crítica. São Paulo: Annablume: Fapesp, 2001.

Políticas sociais e ampliação da cidadania. Rio de Janeiro: FGV, 2000.

Educação Ambiental: o desafio da construção de um pensamento crítico, complexo e reflexivo. Educação e Pesquisa, São Paulo, v. 31, n. 2, p. 233-250, maio/ago. 2005.

KOSÍK, Karel. Dialética do concreto. Tradução de Célia Neves e Alderico Toríbio. Rio de Janeiro: Paz e Terra, 1995.

KRASILCHIK, Miriam. O professor e o currículo de ciências. São Paulo: Edusp, 1987.

LANNER DE MOURA, A. R. A medida e a criança pré-escolar. Tese (Doutorado em Educação). Universidade Estadual de Campinas. Campinas, 1995.

LEFF, Enrique. Epistemologia ambiental. Tradução de Sandra Vanezuela. $2^{a}$ edição. São Paulo: Cortez, 2002.

. Pensar a complexidade ambiental. In: Leff, Enrique (Org.). A complexidade Ambiental. São Paulo: Cortez, 2003.

LEONTIEV. Alexei N. El aprendizaje como problema em la Psicologia. In: LEONTIEV, Alexei N. et al. Psicologia Soviética Contemporânea. La Habana: Instituto del Libro, 1967.

O desenvolvimento do psiquismo. Lisboa: Livros horizonte, 1978. 
1983.

Actividad, Conciencia, Personalidad. Ciudad de La Habana: Pueblo y Educación,

Uma contribuição à teoria do desenvolvimento da psique infantil. In: VIGOTSKII, L. S., LURIA, A. R.; LEONTIEV, A. N. Linguagem, desenvolvimento e aprendizagem. São Paulo: Ícone/Editora da Universidade de São Paulo, 1988.

LIMA, Gustavo Ferreira da Costa. Crise Ambiental, Educação e Cidadania: os desafios da sustentabilidade emancipatória. In: LOUREIRO, C. F. B., LAYRARGUES, P. P., CASTRO, R. S. de (Orgs). Educação Ambiental: repensando o espaço da cidadania. $2^{a}$ ed. São Paulo: Cortez, 2002. p.109-139.

LINDNER,Edson. Ecofilosofando sobre o ambiente. In: KINDEL, Eunice Aita Isaia,SILVA, Fabiano Weber da, SAMMARCO, Yanina Micaela (Orgs). Educação Ambiental: vários olhares e várias práticas. $2^{\mathrm{a}}$ ed. Porto Alegre: Mediação, 2006.

LOUREIRO, C. F. B. Teoria social e questão ambiental: pressupostos para uma práxis crítica em Educação Ambiental. In: LOUREIRO, C. F. B., LAYRARGUES, P. P., CASTRO, R. S. (Orgs). Sociedade e meio ambiente: a educação ambiental em debate. $2^{\mathrm{a}}$ ed. São Paulo: Cortez, 2002. p.13-47.

LURIA, A. R. Uno Sguardo sul passato: considerazione retrospettive sulla vita di uno psicólogo soviético. Firenze: Giunti Barbèra, 1983.

MACHADO, Nilson José. Sobre a idéia de projeto. Ensaios transversais: cidadania e educação. São Paulo: Escrituras Editora, 1997.

MANZOCHI, Lucia H.; SANSOLO, Davis G. Educação, escola e meio ambiente. In: SORRENTINO, Marcos. et al.(org.).Cadernos do III Fórum de educação ambiental. São Paulo: Gaia, 1995.

MARX, Karl. O Capital. São Paulo: Abril, 1985.

Trabalho alienado e superação positiva da auto-alienação humana (Manuscritos econômicos e filosóficos). In: FERNADES, F. (org.). K. Marx, F. Engels - História. São Paulo: Ática, 1983.

MAZZOTTI, Tarso B. Representação social de "problema ambiental": uma contribuição à educação ambiental. Revista Brasileira de Estudos Pedagógicos. Brasília, V. 78, $\mathrm{n}^{\mathbf{o}}$ 188/189/190, p. 86-123, jan./dez., 1997.

MINAYO. M.C.S. O desafio do conhecimento: pesquisa qualitativa em saúde. $4^{a}$ edição. São Paulo-Rio de Janeiro: Hucitec-Abrasco, 1996.

1996a.

(org.). Pesquisa Social: Teoria, Método e Criatividade. $5^{\text {a }}$ edição. Petrópolis: Vozes,

MOLON, Susana Inês. Contribuições Epistemológicas da Perspectiva Sócio-Histórica para a Educação Ambiental. In: GALIAZZI, Maria do Carmo, FREITAS, José Vicente (orgs.). Metodologias Emergentes de Pesquisa em educação ambiental. Ijuí: Unijuí, 2005. 
MORIN, Edgar, KERN, A. B. Terra-Pátria. Lisboa: Instituto Piaget, 1994.

MOURA, Manoel Oriosvaldo de. A construção do signo numérico em situação de ensino. Tese (Doutorado em Educação). Faculdade de Educação da USP. São Paulo, 1992.

A atividade de ensino como unidade formadora. Bolema. Rio Claro, vol. 12, 1996.

O educador matemático na coletividade de formação: uma experiência com a escola pública. Tese (Livre Docência em Educação). Faculdade de Educação da USP. São Paulo, 2000.

A atividade de ensino como ação formadora. In: CASTRO, A. D., CARVALHO, A. M. P. (org.). Ensinar a ensinar. São Paulo: Pioneira, 2001.

NOAL, Fernando Oliveira. Os ritmos e os riscos: considerações sobre globalização, ecologia e contemporaneidade. In: LOUREIRO, C. F. B., LAYRARGUES, P. P., CASTRO, R. S. de (Orgs). Sociedade e meio ambiente: a educação ambiental em debate. $2^{a}$ ed. São Paulo: Cortez, 2002. p.67-84.

OBOUKHOVA, Ludmila. A teoria de Vigostki: O novo paradigma na investigação do desenvolvimento infantil. Tradução: Flávia da Silva Ferreira Asbahr. In: O enfoque histórico cultural em questão. Anais da I Conferência Internacional, Santo André, São Paulo, 2006, p.16-25.

OLIVEIRA, Marta K. Sobre diferenças individuais e diferenças culturais: o lugar da abordagem histórico-cultural. In: AQUINO, Júlio G. (org.). Erro e fracasso na escola: alternativas teóricas e práticas. São Paulo: Summus, 1997.

PONTUSCHKA, Nídia Nacib. Um olhar sobre o Campus - São Paulo Perspectiva Socioambiental. São Paulo: FEUSP, 1999.

REIGOTA, Marcos. A floresta e a escola: por uma educação ambiental pós-moderna. São Paulo: Cortez, 1999.

RUBTSOV, Vitaly. A Atividade de aprendizado e os problemas referentes à formação do pensamento teórico dos escolares. In: GARNIER, C; BEDNARZ, N; ULANNOVSKAYA, I (Orgs.). Após Vygotsky e Piaget: Perspectives Social e Construtivista Escolas Russa e Ocidental. Tradução: Eunice Gruman. Porto Alegre: Artmed, 2003.

SANCHES VÁZQUEZ, A. Filosofia da Práxis. Rio de janeiro: Paz e Terra, 1977.

SANTOS, Boaventura de Sousa. Pela mão de Alice: o social e o político na pósmodernidade. $2^{a}$ ed. São Paulo: Cortez, 1996.

SÃO PAULO (ESTADO). Secretaria do Meio Ambiente/Coordenadoria de Educação Ambiental. Educação Ambiental e desenvolvimento: documentos oficiais. São Paulo: SMA/CEAM, 1994.

SATO, Michele. Educação para o ambiente amazônico. Tese de Doutorado. Universidade de São Carlos, São Carlos, 1997. 
SAUVÉ, Lucie. Uma cartografia das correntes em educação ambiental. In: SATO, M. CARVALHO, I.C.M. (Orgs.). Educação Ambiental: Pesquisa e desafios. São Paulo: Artimed, 2005

SEGURA, Denise de Souza Baena. Venturas e desventuras da EA na Escola Pública: Um estudo de Experiência na Zona Leste do Município de São Paulo. Dissertação de Mestrado Faculdade de Educação da USP, São Paulo, 1999.

Educação ambiental na escola pública: da curiosidade ingênua à consciência crítica. São Paulo: Annablume: Fapesp, 2001.

SERRÃO, Maria Isabel Batista. Estudantes de Pedagogia e a "Atividade de Aprendizagem" de Ensino em formação. Tese de Doutorado em Educação - Universidade de São Paulo, São Paulo, 2004.

SERRES. Michel. O contrato natural. São Paulo: Nova Fronteira, 1990.

SILVA, Eliane Simões. et al. Política Pública de Educação Ambiental da Secretaria de Estado da Educação do Rio Grande do Sul. In: KINDEL, Eunice Aita Isaia,SILVA, Fabiano Weber da, SAMMARCO, Yanina Micaela (Orgs). Educação Ambiental: vários olhares e várias práticas. $2^{\mathrm{a}}$ ed. Porto Alegre: Mediação, 2006.

SOFFIATI, Arthur. As raízes da crise ecológica atual. Ciência e Cultura, 39 (10): out. 1987, 951-954.

Fundamentos Filosóficos e Históricos para o exercício da Ecocidadania e da Ecoeducação. In: LOUREIRO, C.F.B., LAYRARQUES, P.P.,CASTRO, R.S. de.(Orgs.). Educação ambiental: repensando e espaço da cidadania. $2^{a}$ ed. São Paulo: Cortez, 2002. p.2362.

SPINK, M. J. P. Prefácio. In: REIGOTA, M. Ecologistas. Santa Cruz do Sul: Edunisc, 1999.

THOMAS, Keith. O homem e o mundo natural. São Paulo: Cia. Das Cetras, 1988.

TRISTÃO, Martha. Tecendo os fios da educação ambiental: o subjetivo e o coletivo, o pensamento e o vivido. Revista USP, São Paulo, v. 31, n. 2, p. 251-264, maio/agosto, 2005.

As dimensões e os desafios da educação ambiental na sociedade do conhecimento. In: RUSHEINSKY, A. (Org.). Educação Ambiental: abordagens múltiplas. Porto Alegre: Artmed, 2002.

Pedagogia ambiental: uma proposta baseada na interação. Dissertação de Mestrado. Universidade Federal do Espírito Santo. Vitória, 1992.

UNESCO. La educación ambiental: Lãs grandes orientaciones de la Conferencia de Tbilisi. Paris: Unesco, 1980.

VUIGOTSKIJ, L.S. Historia del desarrollo de lãs funciones psíquicas superiores. Ciudad de la Habana: Editorial Científico Técnica, 1987. 
VYGOTSKY, L. A. A formação social da mente. São Paulo: Martins Fontes, 1991.

\section{BIBLIOGRAFIA}

AB'SABER, Aziz. (Re) Conceituando a Educação Ambiental. In: MAGALHÃES. L. E. (coord.). A questão ambiental. São Paulo: Terragrah, 1994.

ANDRÉ, Marli E. D. A pesquisa no cotidiano escolar. In: FAZENDA, Ivani (org.). Metodologia da pesquisa educacional. São Paulo: Cortez, 1997.

BONOTTO, D. M. B. A temática ambiental e a escola pública de ensino médio: conhecendo e apreciando a natureza. Dissertação de mestrado - UNESP, Rio Claro, 1999.

BRUGGER, Paula. Educação ou adestramento ambiental? Santa Catarina: Letras Contemporâneas, 1994.

BURSZTYN, M. (org.). Para pensar o desenvolvimento sustentável. São Paulo: Brasiliense, 1993.

CARVALHO, I. C. M. Educação, meio ambiente e ação política. In: ACSELRAD, H. (org.). Desenvolvimento e meio ambiente. Rio de Janeiro: Ibase, 1993.

Movimentos sociais e políticas de meio ambiente: a Educação Ambiental onde fica? In: SORRENTINO, M. et al. (org.). Cadernos do III Fórum de Educação Ambiental. São Paulo: Gaia, 1995.

CARVAlHO, Luís Marcelo. A Temática ambiental e a escola de $\mathbf{1}^{\mathbf{0}}$ grau. Tese de Doutorado - Universidade de São Paulo, São Paulo, 1989.

CASCINO, Fábio. Educação ambiental: eixos teóricos para uma reflexão curricular. In: São Paulo (Estado). Educação, meio ambiente e cidadania. Reflexões e experiências. São Paulo: SMA/Ceam, 1998. Senac, 1999.

Educação Ambiental: princípio, história, formação de professores. São Paulo:

CASTRO, R. S.; BAETA, A. M. Autonomia Intelectual: condição necessária para o exercício da cidadania. In: LOUREIRO, C. F. B., LAYRARGUES, P. P., CASTRO, R. S. de (Orgs). Educação Ambiental: repensando o espaço da cidadania. $2^{a}$ ed. São Paulo: Cortez, 2002. p. 99-106.

CORTELlA, Mário Sérgio. A escola e o conhecimento: fundamentos epistemológicos e políticos. São Paulo: Cortez, 1998.

DIAS, G. F. Atividades interdisciplinares de educação ambiental. São Paulo: Global/Gaia, 1994. 
DIAS, L. S. Interdisciplinaridade em tempo de diálogo: práticas interdisciplinares na escola. São Paulo: Cortez, 1991.

GADOTTI, Moacir. Cidadania Planetária: pontos para reflexão. São Paulo: Instituto Paulo Freire, 1998.

GONÇALVES, C. W. P. Os (des)caminhos do meio ambiente. São Paulo: Contexto, 1989. GRUN, Mauro. Ética e educação ambiental: a conexão necessária. Campinas: Papirus, 1996.

GUATARRI, F. As três ecologias. Campinas: Papirus, 1993.

GUTIÉRREZ, Francisco e PRADO, Cruz. Ecopedagogia e cidadania planetária. São Paulo: Cortez/Instituto Paulo Freire, 1999.

JACOBI, Pedro Roberto. Meio ambiente urbano e sustentabilidade: alguns elementos para a reflexão. IN: CAVALCANTI, Clóvis (org.). Meio Ambiente, Desenvolvimento Sustentável e Políticas Públicas. São Paulo: Cortez Editora, 1997.

KRASILCHIK, Mirian. "Educação ambiental na escola brasileira: presente, passado e futuro”. Ciência e Cultura, 1986.

.PONTUSCHKA, Nídia Nacib (Coord.) RIBEIRO, Helena (edição). Pesquisa Ambiental: Construção de um Processo Participativo de Educação e Mudança. São Paulo: Editora da Universidade de São Paulo, 2006.

MACEDO, E. F. M. Parâmetros curriculares nacionais: a falácia de seus temas transversais. In: MOREIRA, A. F. B. (org). Currículo: políticas e práticas. São Paulo: Papirus, 1999.

MORIN, Edgar. Epistemologia da complexidade. In: SCHNITMAN, Dora (org.). Novos paradigmas, cultura e subjetividade. Porto Alegre: Artmed Editora, 1996.

MOURA, M. O de. A construção do signo numérico em situação de ensino, tese de doutorado, Universidade de São Paulo, São Paulo, 1992.

NÓVOA, A. N. "Formação de professores e profissão docente", in: NÓVOA, A. N. (org.) Os professores e sua formação, Lisboa, Publicações Dom Quixote, 1992.

NÚÑEZ, Isauro B.; PACHECO, Otmara G. La formación de conceptos científicos: una perspectiva desde la teoria de la actividad. Natal: Editora da Universidade do Rio Grande do Norte, 1997.

ORLANDI, Eni P. O discurso da educação ambiental no Brasil: materiais impressos. São Paulo: Gaia, 1996.

PARO, Vitor. Por dentro da escola pública. São Paulo: Xamã, 1995.

PELICIONI, Andréa F. Educação ambiental na escola: um levantamento de percepções e práticas de estudantes de primeiro grau a respeito de meio ambiente e problemas ambientais. 
Dissertação de Mestrado -Faculdade de Saúde Pública da Universidade de São Paulo, São Paulo, 1997.

PENTEADO, H. D. Meio ambiente e formação de professores. Coleção Questões da Nossa Época. São Paulo: Cortez, 1994.

PERNAMBUCO (ESTADO). Secretaria de Ciência, Tecnologia e Meio Ambiente. Fazendo educação ambiental. Recife: CPRH, 1994.

PERRENOUD, P. Construir as competências desde a escola, Porto Alegre, Artmed Editora, 1999.

Ofício do Aluno e Sentido do trabalho Escolar. Porto: Porto Editora, 1995.

POMPÉIA, S. M. Os parâmetros curriculares e os desafios da escola. Debates Socioambientais, São Paulo: Cedec, ano 2, n. ${ }^{\circ}$ 7, jun. /set. 1997.

PONTUSCHKA, Nídia (org.) Um projeto... tantas visões: educação ambiental na escola pública. São Paulo: LAPECH/FEUSP, 1996. 1993.

Ousadia no diálogo: interdisciplinaridade na Escola Pública. São Paulo: Loyola,

REIGOTA, Marcos. Meio ambiente e representação social. Coleção Questões da Nossa Época. São Paulo: Cortez, 1995.

O que é educação ambiental. São Paulo: Brasiliense, 1994.

. Educação ambiental: autonomia, cidadania e justiça social. Debates socioambientais. São Paulo: Cedec, ano 2, n. ${ }^{\circ}$ 7, jun./set. 1997.

SACRISTÁN, J. G. Consciência e ação sobre a prática como libertação profissional. In: NÓVOA, António (org.) Profissão professor. Porto: Porto Editora, 1995.

SÃO PAULO (Estado). Secretaria do Meio Ambiente/Coordenadoria de Educação Ambiental. Educação Ambiental na Escola Pública. São Paulo: SMA/CEAM, 1994.

SEVERINO, Antonio J. Metodologia do trabalho científico. São Paulo: Cortez, 1996.

SIMÕES, Eliane. Uma educação ambiental possível, a natureza do programa da ilha. Dissertação de Mestrado. Faculdade de Educação da PUC, São Paulo, 1995. 


\section{ANEXO A - Questionário inicial}

1) Gostaria de continuar participando dos nossos próximos encontros? Justifique.

2) O que você achou da proposta de trabalho desta oficina?

3) Você trabalha com atividades de Educação Ambiental em suas aulas? Por quê?

4) Em uma escala de 0 a 5, que importância você dá para as atividades de Educação Ambiental como:

a) pessoa:

b) $\operatorname{professor}(\mathrm{a})$ :

5) Como prefere trabalhar com as atividades de Educação Ambiental: nas aulas de Ciências apenas ou de maneira interdisciplinar? Justifique.

6) Existe alguma dificuldade em se trabalhar com atividades de Educação Ambiental? Justifique.

7) As atividades de Educação Ambiental são previstas no Planejamento Escolar ou vão surgindo durante o ano no desenvolvimento dos conteúdos?

8) Como é a participação dos seus alunos nas atividades de Educação Ambiental?

9) Acredita que suas atividades de Educação Ambiental se constituem como atividades de aprendizagem? Justifique? 
ANEXO B - Questões norteadoras para a entrevista ATP Ciências e Biologia.

1) Qual a concepção de Educação Ambiental da Oficina Pedagógica?

2) Como os projetos de Educação Ambiental são desenvolvidos: em conjunto com todos os ATPs e em todas as áreas ou fica a cargo de alguns em específico?

3) Como esses projetos são concebidos: a própria oficina os elabora ou eles são desenvolvidos apenas quando são encaminhadas pela SEE ou outro órgão?

4) Como esses projetos geralmente são desenvolvidos com as escolas?

5) Há um envolvimento de todas as escolas?

6) Como a avaliação desses projetos é feita?

7) No ponto de vista de vocês, como a Educação Ambiental vem sendo desenvolvida no Ensino Fundamental especificamente? Como vocês observam a participação dos professores?

8) Quem é responsável por desenvolver esses projetos no Ensino Fundamental?

9) A ATP responsável pelo ensino fundamental desenvolve algum trabalho específico com os professores e as escolas com relação à Educação Ambiental? 


\section{ANEXO C - Proposta da Oficina de Educação Ambiental}

Tema: Educação Ambiental na $3^{\mathrm{a}}$ e $4^{\mathrm{a}}$ séries do Ensino Fundamental I: práticas e percepções.

Público Alvo: Professores de $3^{\mathrm{a}}$ e $4^{\mathrm{a}}$ séries do Ensino Fundamental I da Diretoria de Ensino Centro-Sul.

Período: Outubro de 06 a Maio de 07.

Carga Horária: 20 horas (5 encontros de 4 horas)

Local: Oficina Pedagógica da Diretoria de Ensino Centro Sul.

Coordenação: Prof. Antonio César Bigotto - Mestrando pela Faculdade de Educação da USP e ATPs de Ciências e Biologia e de Ensino Fundamental I.

Período de realização: Outubro de 2006 a Maio de 2007

\section{Justificativa.}

Um dos grandes marcos na vida de qualquer pessoa é o seu ingresso na vida escolar. A partir desse momento, o âmbito e a qualidade das relações sociais estabelecidas são redimensionados. Novas exigências surgem, novas habilidades e atitudes passam pouco a pouco a formar a pessoa. A qualidade do processo de aprendizagem, portanto, também se altera. A aprendizagem ocorrida por meio das brincadeiras, do convívio com os adultos ou até mesmo do trabalho precoce é distinta da que ocorre na escola. A educação escolar oferece a possibilidade sistematizada de apropriação de parte dos elementos da produção cultural de uma dada formação social em determinado período de tempo, vinculada à "consciência e pensamentos teóricos". Nesse sentido, na escola, a aprendizagem é o objetivo principal. Em outras palavras, a aprendizagem é decorrência de um ensino que proporcione a atividade de aprendizagem. (SERRÃO, 2004).

Por ocasião da Conferência Internacional Rio/92, cidadãos representando instituições de mais de 170 países assinaram tratados nos quais se reconhece o papel central da educação para a construção de um mundo socialmente justo e ecologicamente equilibrado, o que requer responsabilidade individual e coletiva em níveis local, nacional e planetário (PCN, 1997). E é isso que se espera da Educação Ambiental no Brasil que foi assumida como obrigação pela Constituição promulgada em 1988. A Educação Ambiental como elemento indispensável para se conseguir criar e aplicar formas cada vez mais sustentáveis de interação sociedade-natureza e solução para os problemas ambientais.

De acordo com Pontuschka, o estudo das questões ambientais e a tomada de consciência da importância do sistema Terra, quase sempre fechado, vem sendo lento, havendo somente tentativas pontuais desvinculadas do currículo escolar. Além disso, os professores nem sempre podem contribuir satisfatoriamente com projetos de Educação 
Ambiental, porque eles não têm informações suficientes para propor pesquisas em sala de aula ou na escola para que os estudantes possam trabalhar com documentos já existentes e tenham condições, sob a orientação do professor, de produzir novos documentos que auxiliem a ambos na reflexão e solução de certos problemas. (PONTUSCHKA, 1999).

Nem todo ensino ou educação escolar promove o desenvolvimento psicológico da criança. Para que isso ocorra, faz-se necessário organizar a "atividade" dos estudantes e dos professores na escola com o objetivo de promover situações que contribuam para a superação, pelo menos, do pensamento empírico (SERRÃO,2004). Para essa organização, partiremos das concepções da "Atividade Orientadora de Ensino", que segundo Moura (2000), organiza-se dos seguintes elementos básicos: intencionalidade do professor, explicitação de uma situação problema, momentos de interação entre as crianças, o professor e as diferentes fontes, em busca de possíveis formas de resolução do problema apresentado.

Objetivo Geral: verificar quais as bases teóricas e as concepções que sustentam as práticas de Educação Ambiental desenvolvidas pelas professoras de Ensino Fundamental I, assim como analisar o desenvolvimento e a avaliação dessas práticas.

\section{Objetivos Específicos:}

- discutir os fundamentos teóricos e os propósitos da Educação Ambiental a partir de alguns documentos oficiais como as Propostas Curriculares da Secretaria Estadual da Educação de São Paulo e os Parâmetros Curriculares Nacionais do Ministério da Educação e Cultura;

- apropriar os professores de informações e conhecimentos atualizados sobre as pesquisas e práticas na área da Educação Ambiental;

- refletir juntamente com os professores sobre as práticas de Educação Ambiental que vem sendo desenvolvidas no ensino fundamental,

- verificar o vinculo dessas práticas com o currículo escolar;

- discutir com os professores as características e os princípios de Atividades de Aprendizagem e das Atividades Orientadoras de Ensino;

- analisar conjuntamente com as professoras se as suas práticas de Educação Ambiental podem se caracterizar como Atividades Orientadoras de Ensino e em caso negativo, discutir quais mudanças seriam necessárias para esse enquadramento; 


\section{ANEXO D - Correntes em Educação Ambiental}

Aponte 2 (duas) correntes que mais se aproximam do seu trabalho em sala de aula com relação às suas práticas de Educação Ambiental.

( ) CORRENTE 01

- centrada na relação com a natureza;

- enfoque educativo pode ser cognitivo (aprender com as coisas da natureza), experiencial (viver na natureza e aprender com ela), afetivo, espiritual ou artístico (associando a criatividade humana à da natureza);

\section{( ) CORRENTE 02}

- proposições centradas na conservação dos recursos;

- preocupação com a "administração do meio ambiente" (gestão ambiental), ex.: Programa dos 3 "R"s;

\section{( ) CORRENTE 03}

- trata-se de informar ou de levar as pessoas a se informarem sobre as problemáticas ambientais, assim como a desenvolver habilidades voltadas para resolvê-las;

- ação: modificação de comportamentos e projetos coletivos;

\section{( ) CORRENTE 04}

- enfoque que permite conhecer e compreender adequadamente as realidades e as problemáticas ambientais;

- O enfoque das realidades é de natureza cognitiva e a perspectiva é a de tomada de decisões ótimas;

- Habilidades ligadas à análise e à síntese;

- Modelo pedagógico centrado na saída a campo: observar a problemática, analisar seus componentes, desenvolver um modelo sistêmico para compreensão da realidade, identificar e escolher a solução mais apropriada;

\section{( ) CORRENTE 05}

- abordar com rigor as realidades e problemáticas ambientais para compreendê-las melhor;

- enfoque sobretudo cognitivo: o meio ambiente é objeto de conhecimento para melhor escolher uma solução ou ação apropriada;

- perspectiva: compreender melhor para orientar melhor;

- situa-se no contexto do ensino das ciências naturais;

- adota modelo sistêmico e interdisciplinar;

\section{( ) CORRENTE 06}

- dá ênfase à dimensão humana do meio ambiente;

- o enfoque do meio ambiente é dado sob a ótica da geografia e/ou outras ciências humanas;

- trabalho com estudo do meio;

\section{( ) CORRENTE 07}

- o fundamento da relação com o meio ambiente é de ordem ética; 
- as proposições de educação enfatizam o desenvolvimento dos valores ambientais, adoção de uma "moral" ambiental;

- desenvolvimento moral dos alunos;

\section{( ) CORRENTE 08}

- enfoque exclusivamente analítico e racional das realidades ambientais encontra-se na origem de muitos problemas atuais;

- desenvolver um conhecimento orgânico do mundo e um atuar participativo em e com o meio ambiente;

\section{( ) CORRENTE 09}

- refere-se a um sentimento de identidade entre as comunidades humanas que ali vivem;

- conhecimento do meio e desejo de adotar modos de vida que contribuirão para a valorização da comunidade natural da região;

- enfoque participativo e comunicativo: convoca os pais e outros membros da comunidade;

\section{( ) CORRENTE 10}

- ênfase esta na aprendizagem na ação, pela ação e para a melhora desta;

- integra reflexão e ação que se alimentam mutuamente;

- pesquisa- ação para resolução de problemas comunitários;

- transformar as maneiras tradicionais de ensinar e aprender;

\section{( ) CORRENTE 11}

- análise das dinâmicas sociais que se encontram na base das realidades e problemáticas ambientais;

- aponta para a transformação das realidades;

- projetos elaborados a partir de uma perspectiva comunitária;

- encaminhamentos para órgãos municipais;

\section{( ) CORRENTE 12}

- análise e denúncia das relações de poder dentro dos grupos sociais;

- a ênfase está nas relações de poder que os homens ainda exercem sobre as mulheres em certos contextos;

\section{( ) CORRENTE 13}

- dá ênfase ao caráter cultural da relação com o meio ambiente;

- leva em conta a cultura de referência das populações ou comunidades envolvidas;

\section{( ) CORRENTE 14}

- dominada pela perspectiva educacional da Educação Ambiental;

- não se trata de resolver problemas, mas aproveitar a relação com o meio ambiente para o desenvolvimento pessoal, num atuar significativo e responsável;

\section{( ) CORRENTE 15}

- ideologia do desenvolvimento sustentável;

- enfoque naturalista que integra preocupações sociais; 
ANEXO E - ANÁLISE DOS CONTEÚDOS DE MEIO AMBIENTE PARA O PRIMEIRO E SEGUNDO CICLOS

\section{CRITÉRIOS:}

Claro: compreende perfeitamente e sabe como desenvolver;

Pouco Claro: conhece, mas não tem muita clareza, e tem dificuldades em desenvolver;

Muito Confuso: não sabe o que tem que ser trabalhado e desenvolvido;

\section{BLOCO 01 - OS CICLOS DA NATUREZA}

\begin{tabular}{|c|c|c|c|c|}
\hline Ítem & Conteúdo & Claro & $\begin{array}{l}\text { Pouco } \\
\text { Confuso }\end{array}$ & $\begin{array}{l}\text { Muito } \\
\text { Confuso }\end{array}$ \\
\hline 01 & $\begin{array}{l}\text { Os ciclos da água, seus múltiplos usos e sua importância } \\
\text { para a vida, para a história dos povos; }\end{array}$ & & & \\
\hline 02 & $\begin{array}{l}\text { Os ciclos da matéria orgânica e sua importância para o } \\
\text { saneamento; }\end{array}$ & & & \\
\hline 03 & $\begin{array}{l}\text { As teias e cadeias alimentares, sua importância e o risco } \\
\text { de transmissão de substâncias tóxicas que possam estar } \\
\text { presentes na água, no solo e no ar; }\end{array}$ & & & \\
\hline 04 & $\begin{array}{l}\text { O estabelecimento de relações e correlações entre } \\
\text { elementos de um mesmo sistema; }\end{array}$ & & & \\
\hline 05 & $\begin{array}{l}\text { A observação de elementos que evidenciam ciclos e } \\
\text { fluxos na natureza, no espaço e no tempo. }\end{array}$ & & & \\
\hline
\end{tabular}

BLOCO 02 - SOCIEDADE E MEIO AMBIENTE

\begin{tabular}{|c|c|c|c|c|}
\hline Ítem & Conteúdo & Claro & $\begin{array}{l}\text { Pouco } \\
\text { Confuso }\end{array}$ & $\begin{array}{l}\text { Muito } \\
\text { Confuso }\end{array}$ \\
\hline 01 & A diversidade cultural e a diversidade ambiental; & & & \\
\hline $\mathbf{0 2}$ & $\begin{array}{l}\text { Os limites da ação humana em termos quantitativos e } \\
\text { qualitativos; }\end{array}$ & & & \\
\hline 03 & $\begin{array}{l}\text { As principais características do ambiente e/ou paisagem } \\
\text { da região em que se vive; as relações pessoais e } \\
\text { culturais dos alunos e de sua comunidade com os } \\
\text { elementos dessa paisagem; }\end{array}$ & & & \\
\hline 04 & $\begin{array}{l}\text { As diferenças entre ambientes preservados, degradados, } \\
\text { causas e consequêencias para a qualidade de vida das } \\
\text { comunidades, desde o entorno imediato até de outros } \\
\text { povos que habitam a região e o planeta, bem como das } \\
\text { gerações futuras; }\end{array}$ & & & \\
\hline 05 & A interdependência ambiental entre áreas urbana e rural & & & \\
\hline
\end{tabular}


BLOCO 03 - MANEJO E CONSERVAÇÃO AMBIENTAL

\begin{tabular}{|c|c|c|c|c|}
\hline Ítem & Conteúdo & Claro & $\begin{array}{l}\text { Pouco } \\
\text { Confuso }\end{array}$ & $\begin{array}{l}\text { Muito } \\
\text { Confuso }\end{array}$ \\
\hline 01 & $\begin{array}{l}\text { O manejo e a conservação da água: noção sobre } \\
\text { captação, tratamento e distribuição para o consumo; os } \\
\text { hábitos de utilização da água em casa e na escola } \\
\text { adequados às condições locais; }\end{array}$ & & & \\
\hline 02 & $\begin{array}{l}\text { A necessidade e formas de tratamento dos detritos } \\
\text { humanos: coleta, destino e tratamento do esgoto; } \\
\text { procedimentos possíveis adequados às condições } \\
\text { locais (sistema de esgoto, fossa e outros); }\end{array}$ & & & \\
\hline 03 & $\begin{array}{l}\text { A necessidade e as formas de coleta e destino do lixo; } \\
\text { reciclagem; os comportamentos responsáveis de } \\
\text { "produção" e "destino" do lixo em casa, na escola e } \\
\text { nos espaços de uso comum; }\end{array}$ & & & \\
\hline 04 & $\begin{array}{l}\text { As formas perceptíveis e imperceptíveis de poluição } \\
\text { do ar, da água, do solo e poluição sonora; principais } \\
\text { atividades locais que provocam poluição (indústrias, } \\
\text { mineração, postos de gasolina, curtumes, matadouros, } \\
\text { criações, atividades agropecuárias, em especial as de } \\
\text { uso intensivo de adubos químicos e agrotóxicos, etc.); }\end{array}$ & & & \\
\hline 05 & $\begin{array}{l}\text { Noções de manejo e conservação do solo: erosão e } \\
\text { suas causas nas áreas rurais e urbanas; necessidade e } \\
\text { formas de uso de insumos agrícolas, cuidados com a } \\
\text { saúde; }\end{array}$ & & & \\
\hline 06 & $\begin{array}{l}\text { Noções e procedimentos adequados com plantas e } \\
\text { animais; cuidados com a saúde; }\end{array}$ & & & \\
\hline 07 & $\begin{array}{l}\text { A necessidade e as principais formas de preservação, } \\
\text { recuperação e reabilitação ambientais, de acordo com } \\
\text { a realidade local; }\end{array}$ & & & \\
\hline 08 & $\begin{array}{l}\text { Alguns processos simples } \\
\text { reaproveitamento de materiais; }\end{array}$ & & & \\
\hline 09 & $\begin{array}{l}\text { Os cuidados necessários para o desenvolvimento das } \\
\text { plantas e dos animais; }\end{array}$ & & & \\
\hline 10 & $\begin{array}{l}\text { Os procedimentos corretos com dejetos humanos nos } \\
\text { banheiros e em lugares onde não haja instalações } \\
\text { sanitárias; }\end{array}$ & & & \\
\hline 11 & $\begin{array}{l}\text { As práticas que evitam desperdícios no uso cotidiano } \\
\text { de recurso como água, energia e alimentos; }\end{array}$ & & & \\
\hline 12 & $\begin{array}{l}\text { A valorização de formas conservativas de extração, } \\
\text { transformação e uso dos recursos naturais. }\end{array}$ & & & \\
\hline
\end{tabular}


This document was created with Win2PDF available at http://www.win2pdf.com.

The unregistered version of Win2PDF is for evaluation or non-commercial use only.

This page will not be added after purchasing Win2PDF. 